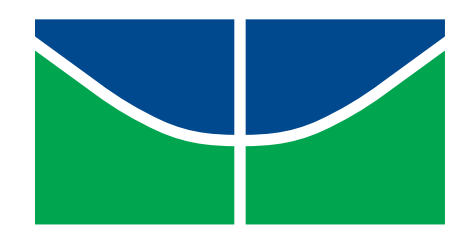

\author{
Universidade de Brasília \\ Instituto de Ciências Exatas \\ Departamento de Matemática
}

\title{
A Matemática Financeira no Ensino Médio: Uma Nova Visão
}

\author{
por \\ André Luiz Pontes Pavoni
}

Brasília, 2016 


\section{A Matemática Financeira no Ensino Médio: Uma Nova Visão}

Dissertação apresentada ao Departamento de Matemática da Universidade de Brasília, como parte dos requisitos do "Programa" de Mestrado Profissional em Matemática em Rede Nacional - PROFMAT, para a obtenção do grau de

\section{MESTRE}

Orientador: Prof. Dr. Rui Seimetz

Co-orientador: Prof. Msc Lineu da C. Araújo Neto

Brasilia

2016 


\section{A Matemática Financeira no Ensino Médio: Uma Nova Visão}

por

\section{André Luiz Pontes Pavoni*}

Dissertação apresentada ao Departamento de Matemática da Universidade de Brasília, como parte dos requisitos do "Programa" de Mestrado Profissional em Matemática em Rede Nacional - PROFMAT, para obtenção do grau de

\section{MESTRE}

Brasília, 04 de julho de 2016.

Comissão Examinadora:

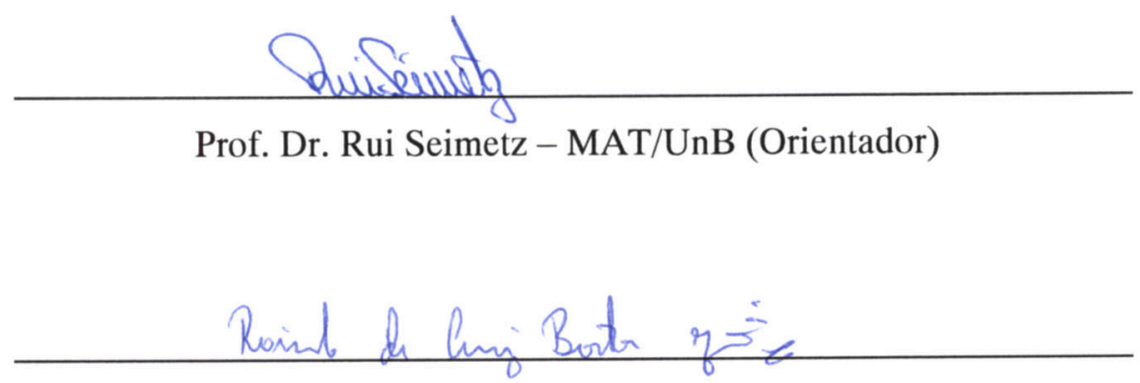

Prof. Dr. Raimundo de Araújo Bastos Júnior - MAT/UnB

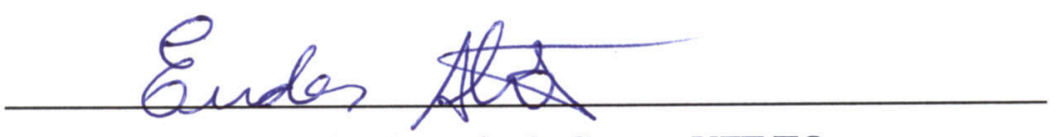

Prof. Dr. Eudes Antonio da Costa - UFT/TO

* O autor foi bolsista CAPES durante a elaboração desta dissertação. 


\section{DEDICATÓRIA}

Dedico este trabalho à minha família que, com muito carinho e apoio, não mediram esforços para que eu chegasse até aqui. Meu amor por vocês é incondicional. 


\section{Agradecimentos}

Agradeço primeiramente a Deus, pelo dom da vida. Aos meus pais Luiz e Toinha, por serem meus exemplos. À minha esposa Marina, pelo amor, apoio e incentivo. Aos meus filhos Théo e Sofia, razões do meu viver. Sem a força de vocês eu jamais conseguiria chegar até aqui.

Agradeço aos Professores do curso, em especial ao Professor Doutor Rui Seimetz e Mestre Lineu Neto, que me orientaram neste trabalho.

À minha turma, exemplo de união e força nos momentos mais difíceis do Curso.

Ao meu chefe Trajano e à minha equipe de trabalho da CAIXA, pelo companheirismo e apoio na minha ausência para estar aqui na UnB.

Enfim, obrigado a todos aqueles que participaram e torceram para a concretização de mais esse sonho. 


\section{Resumo}

Nesse trabalho é apresentada uma proposta para o desenvolvimento da aprendizagem da Matemática Financeira no $3^{\circ}$ ano do Ensino Médio por meio da Educação Financeira, utilizando situações cotidianas e focando num resultado mais significativo na vida do educando.

O consumismo e a falta de planejamento se tornaram comum na realidade de grande parte da população. Com o advento da globalização e dos programas sociais do Governo Federal, criou-se a possibilidade de pessoas de quaisquer classes sociais terem acesso a bens de consumo, bem como obtenção de créditos com mais facilidade que outrora o teriam, criando um ciclo consumista.

O principal objetivo é proporcionar uma nova visão sobre a matemática levando os alunos a refletirem sobre os diversos ângulos em que podem ser mostrados os assuntos de modo a desenvolver nos alunos uma vontade de aprender e avançar no estudo da Matemática Financeira que podem e devem ser aplicadas no dia-a-dia das pessoas.

Palavras-chave: Educação Financeira. Matemática Financeira. Uma nova visão. Consumismo. Aplicabilidade. 


\begin{abstract}
This work has as objective to present a proposal for the learning development of Financial Mathematics of the 3rd year of high school through Financial Education, using everyday situations and focusing in a more significant result in the student's life.

The consumerism and the lack of planning has become a usual reality of the majority of the population. With the advent of globalization and social programs of the Federal Government, it created the possibility of people from any social class to access consumer goods and to obtain credit more easily than before, creating a consumerist cycle.

The main objective is to provide a new insight of mathematics leading students to reflect on the various angles that the subjects can be shown in order to develop in students a desire to learn and advance in Financial Mathematics study that can and should be applied on day-by-day lives.
\end{abstract}

Keywords: Financial Education, Financial Mathematics, new insight, consumerismand, applicability. 


\section{Sumário}

$\begin{array}{ll}\text { Introdução } & 1\end{array}$

1 Educação Financeira 3

1.1 Educação emocional como base para a educação financeira . . . . . . . . 4

1.2 A educação financeira . . . . . . . . . . . . . . . . . . . 5

1.2.1 Orçamento pessoal ou familiar . . . . . . . . . . . . . 6

1.2.2 Entendendo sua gestão orçamentária . . . . . . . . . . . . . . . . . . . . . . .

1.2.3 Uso do crédito . . . . . . . . . . . . . . . . . . . . . . . 10

1.2.4 Como sair das dívidas . . . . . . . . . . . . . . . . . . . . . . . . . . . . . . . . . .

1.2.5 Investindo seus recursos . . . . . . . . . . . . . . . 17

2 Matemática Financeira $\quad 25$

2.1 Um pouco de história . . . . . . . . . . . . . . . . . . . . 26

2.2 Matemática Financeira e Inflação . . . . . . . . . . . . . . . . . . . 30

2.2.1 Comportamento acumulativo da taxa de inflação . . . . . . . . 33

2.2.2 Taxa de desvalorização da moeda . . . . . . . . . . . . . . . 35

2.2.3 Taxa Referencial - TR . . . . . . . . . . . . . . . . . 35

2.2.4 Caderneta de Poupança . . . . . . . . . . . . . . . . . 36

2.3 Valor atual de um conjunto de capitais . . . . . . . . . . . . . . . . 37

2.4 Sistemas de amortização de empréstimos e financiamentos . . . . . . . 38

2.4.1 Sistema de amortização constante (SAC) . . . . . . . . . . . . . 40

2.4.2 Sistema de amortização francesa $(\mathrm{SAF})$. . . . . . . . . . . . . 44

2.5 Montante de uma sequência uniforme de depósitos . . . . . . . . . . . . 48

2.5.1 Quanto devo depositar por mês para ter uma certa aposentadoria complementar? .................. . . 50

3 Proposta de atividades educacionais $\quad 55$

3.1 Objetivos . . . . . . . . . . . . . . . . . . . 55

3.2 Público-alvo e pré-requisitos . . . . . . . . . . . . . 55

3.3 Materiais e tecnologias . . . . . . . . . . . . . 56 
3.4 Recomendações metodológicas . . . . . . . . . . . . . . . . . . . 56

3.5 Dificuldades previstas . . . . . . . . . . . . . . . . . 57

3.6 Descrição geral . . . . . . . . . . . . . . . . . . . 57

3.7 Utilizando a calculadora e a planilha eletrônica . . . . . . . . . . . . . 57

3.8 Atividade 1: Taxa de inflação e ganho real + Caderneta de Poupança . 59

3.9 Atividade 2: Valor atual de um conjunto de capitais . . . . . . . . . . 60

3.10 Atividade 3: Sistemas de amortização . . . . . . . . . . . . . . 62

3.11 Atividade 4: Montante de uma sequência uniforme de depósitos . . . . 68

3.12 Atividade 5: Questões sobre o assunto aplicadas no ENEM . . . . . . . 70

4 Considerações Finais $\quad 73$

$\begin{array}{ll}\text { Referências Bibliográficas } & 75\end{array}$ 


\section{Lista de Figuras}

2.1 valor da contribuição para diferentes níveis de aposentadoria complementar com taxa de $3 \%$ a.a. . . . . . . . . . . . . . . 53

2.2 valor da contribuição para diferentes níveis de aposentadoria complementar com taxa de $4 \%$ a.a. . . . . . . . . . . . . . . . 53

2.3 valor da aposentadoria complementar para diferentes níveis de tempo e aplicação inicial numa taxa de $3 \%$ a.a. . . . . . . . . . . . . 54

2.4 valor da aposentadoria complementar para diferentes níveis de tempo e aplicação inicial numa taxa de $4 \%$ a.a. . . . . . . . . . . . . . . . . . 54

3.1 Modelo de calculadora presente nos computadores com sistema operacional Windows . . . . . . . . . . . . . . . . . . . . 58

3.2 Financiamento de $\mathrm{R} \$ 140$ mil por 240 meses no SAC . . . . . . . . 63

3.3 Financiamento de $\mathrm{R} \$ 140$ mil por 240 meses na tabela PRICE . . . . . 64 


\section{Lista de Tabelas}

2.1 Índice geral de preços $(\mathrm{FGV}) \ldots \ldots \ldots \ldots \ldots \ldots$

2.2 IGP-di e INPC de um período passado . . . . . . . . . . . . . . 32

2.3 Cálculos da taxa de inflação segundo os índices IGP e INPC . . . . . . 32

2.4 Exemplo 2.4.1 pago pelo SAC em 10 prestações semestrais, sem carência 41

2.5 SAC com carência onde os juros são pagos durante a carência . . . . . 42

2.6 SAC com carência onde os juros são capitalizados e pagos totalmente quando do vencimento da primeira amortização . . . . . . . . . . . 42

2.7 SAC com carência onde os juros são capitalizados e acrescidos ao saldo devedor gerando um fluxo de amortizações de maior valor . . . . . . . . 43

2.8 solução do exemplo $2.4 .2 \ldots \ldots \ldots$. . . . . . . . . . . . . . . . 43

2.9 solução do exemplo $2.4 .3 \ldots \ldots \ldots$. . . . . . . . . . . . . . 44

2.10 Exemplo 2.4.1 pago pelo SPC em 10 prestações semestrais, sem carência 46

2.11 SPC com carência onde os juros são pagos durante a carência $\quad \ldots .46$

2.12 SPC com carência onde os juros são capitalizados e acrescidos ao saldo devedor gerando um fluxo de amortizações de maior valor . . . . . . . . 47

2.13 Montante obtido por 20 depósitos mensais de $\mathrm{R} \$ 500,00$ a uma taxa de

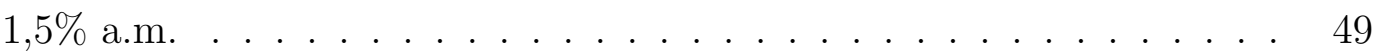

3.1 Exercício 1 resolvido pela tabela PRICE . . . . . . . . . . . . 65

3.2 Exercício 1 resolvido pelo sistema $\mathrm{SAC} \ldots \ldots \ldots \ldots$

3.3 Exercício 2 resolvido pela tabela PRICE . . . . . . . . . . . 65

3.4 Exercício 2 resolvido pelo sistema $\mathrm{SAC} \ldots \ldots \ldots \ldots$

3.5 Exercício 3 resolvido pela tabela PRICE $\ldots \ldots \ldots \ldots 6$

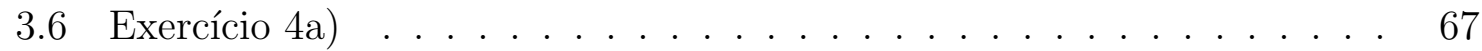

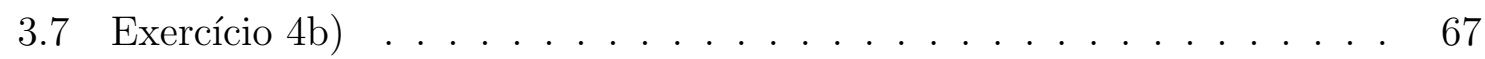

3.8 Exercício 5 usando a tabela PRICE . . . . . . . . . . . . . . 68

3.9 Exercício 5 usando o sistema $\mathrm{SAC} \ldots \ldots \ldots \ldots \ldots$

3.10 Questão ENEM $2011 \ldots \ldots \ldots \ldots \ldots$ 


\section{Introdução}

Atualmente o aluno passa nove anos no ensino fundamental, três anos no ensino médio e, durante esses doze anos de educação básica, é obrigado a memorizar nomes e datas de pouca utilidade na vida real. Em pouco tempo, quase tudo é esquecido.

Nesse período, ele não estuda noções de comércio, economia, finanças ou impostos. O sistema educacional "ignora" o assunto dinheiro, algo incompreensível, já que a alfabetização financeira é fundamental para ser bem sucedido.

A matemática financeira que é trabalhada no ensino médio, apesar de ser relacionada com outros assuntos trabalhados em matemática, não condiz à realidade do aluno em sua vida.

\footnotetext{
A Matemática no Ensino Médio tem um valor formativo, que ajuda a estruturar o pensamento e o raciocínio dedutivo, porém também desempenha um papel instrumental, pois é uma ferramenta que serve para a vida cotidiana e para muitas tarefas específicas em quase todas as atividades humanas.

Para que essa etapa da escolaridade possa complementar a formação iniciada na escola básica e permitir o desenvolvimento das capacidades que são os objetivos do ensino de Matemática, é preciso rever e redimensionar alguns dos temas tradicionalmente ensinados.
}

Brasil, 2002

Foi pensando nesse déficit que está sendo proposto o estudo seguinte para os alunos do $3^{\circ}$ ano do ensino médio com foco na educação financeira e em uma complementação da matemática financeira já trabalhada durante o ensino médio, momento que o aluno está mais maduro, psicologicamente e matematicamente, utilizando situações cotidianas e focando num resultado mais significativo na vida do educando, incentivando os alunos, a comunidade e os professores a uma cultura poupadora e investidora, contrapondo-se à consumista.

Sendo assim o trabalho está dividido em três capítulos, conforme segue:

No capítulo 1 será abordada a Educação Financeira, onde a ideia é incentivar o planejamento financeiro levando a pessoa a uma cultura poupadora, se possível for. 
No capítulo 2 o assunto é a Matemática Financeira, sendo proposta uma complementação do assunto, já trabalhado no ensino médio, buscando maior aplicação do tema na vida cotidiana do aluno.

No capítulo 3 é apresentada uma proposta de atividades educacionais, onde o objetivo é trazer uma sugestão para aplicação em sala de aula usando o telefone celular, planilhas eletrônicas ou calculadora com diversos exercícios contextualizados. 


\section{Capítulo 1}

\section{Educação Financeira}

Neste capítulo evidencia-se a importância da educação financeira no intuito de reforçar conhecimento necessário para a tomada de decisões financeiras conscientes, que propiciem a participação dos envolvidos no processo de desenvolvimento econômico do país.

Para a Estratégia Nacional de Educação Financeira - ENEF a educação financeira pode ser definida como o processo mediante o qual os indivíduos e as sociedades melhoram sua compreensão dos conceitos e dos produtos financeiros, de maneira que, com informação, formação e orientação claras, adquiram os valores e as competências necessários para se tornarem conscientes das oportunidades e dos riscos neles envolvidos e, então, façam escolhas bem informados, saibam onde procurar ajuda, adotem outras ações que melhorem o seu bem-estar, contribuindo, assim, de modo consistente para formação de indivíduos e sociedades responsáveis, comprometidos com o futuro.

Atualmente, muitas famílias têm seu orçamento familiar comprometido pelo impulso de comprar imediatamente o que querem, em detrimento da possibilidade de planejarem a compra ao longo do tempo. Por isso, a conscientização do orçamento familiar bem administrado deve ser objetivo, compreendido por todos os membros da família.

Segundo D'Aquino (2008), é importante que as pessoas saibam o valor do dinheiro em relação ao trabalho, e que o consumo deve vir após as necessidades básicas. Segundo a autora, as famílias desejam ter cada vez mais dinheiro, mas dificilmente elas se propõem a ensinar seus filhos como tratá-lo corretamente, consequentemente, não há educação financeira; não se aprende como ganhar, poupar, gastar ou doar dinheiro.

Para Kiyosaki (2000), a educação financeira traz um padrão de vida desejável e proporciona a sua manutenção. O que todos querem ser é abastados e isso exige conhecimento sobre dinheiro: é o que se chama "inteligência financeira". 


\subsection{Educação emocional como base para a educação financeira}

Segundo Martins (2004), o ser humano é resultado mais das suas emoções do que das suas habilidades técnicas. Nenhum conhecimento levará você a um determinado objetivo se as suas emoções forem inadequadas para alcançar tal objetivo; a relação com o dinheiro não é diferente. A nossa trajetória financeira se dá em três pontos: como ganhamos, como gastamos e como conservamos nosso dinheiro.

Martins (2004) afirma que a maneira como cada um ganha, gasta e conserva dinheiro é resultado de uma combinação de emoções e habilidades, onde emoções são traços de personalidade e habilidades são técnicas aprendidas pelo estudo e pela experiência.

Problemas financeiros familiares podem ser consequências de decisões ou escolhas ruins. Se uma pessoa enfrenta dificuldades dessa natureza, a culpa não é dos juros elevados dos bancos, mas sim de um padrão de vida elevado demais para a renda da família. Ela deve hoje em função de uma compra feita no passado em um momento em que não havia dinheiro para isso. Isso ocorre por pura ingenuidade.

No estereótipo de uma família financeiramente bem sucedida, os tamanhos da casa e do carro crescem ao longo dos anos, os filhos tem brinquedos e eletrônicos da moda e ganham carro ao entrar na faculdade, a casa de campo ou de praia vira destino de fim de semana dos amigos dos filhos e o casamento dos jovens é totalmente pago pelos pais. Eis um verdadeiro conto de fadas da classe média.

Ainda hoje, porém, grande parte das famílias que conquistam esses sonhos se esquece de pensar no futuro e tem um destino semelhante: venda de bens para pagar tratamentos de saúde, aposentadoria com falta de dinheiro e queda significativo no padrão de vida. Emoções inadequadas sabotam qualquer habilidade técnica que você tenha para manipular seu dinheiro.

D’Aquino (2008) menciona que sempre haverá uma situação de escolhas envolvida em cada ato de consumo, porque a população não foi educada para perceber o uso do dinheiro como resultado das escolhas que faz, ou a considerar o que deixou de ganhar quando fez uma opção.

Claro que desejar coisas é uma emoção legítima do ser humano e sua ausência pode significar, muitas vezes, ausência de vida e alegria. O problema não é o desejo e sim transformar esse desejo em algo que extrapola os limites do bom senso, tornando-o excessivo e passando a causar problemas.

O desejo em excesso ofusca a razão e a racionalidade e as pessoas que tem compulsão ao consumo não são pessoas que apenas desejam coisas; elas compram por impulso, compram em exagero e, consequentemente, compram o que não precisam com o dinheiro que não tem.

Martins (2004) cita que a necessidade de ostentar e a vaidade excessiva são emoções 
que conduzem a pessoa a fazer gastos exagerados, na hora errada, de maneira impensada e abusiva, transformando-a numa máquina de destruir dinheiro. Agir assim significa pavimentar o caminho para o abismo de problemas financeiros, e isso ocorre mesmo com pessoas ricas, que acabam quebrando.

\subsection{A educação financeira}

Segundo D'Aquino, a escola pode e deve exercer seu papel no sentido de incentivar o consumo consciente e o pensamento crítico de seus alunos com relação aos mais diversos assuntos, e não somente com relação ao dinheiro. Esse estímulo ao senso crítico fará com que os alunos se tornem adultos mais maduros e conscientes, o que terá aplicação estendida às questões financeiras.

Uma iniciativa que pode ser citada é a ENEF, ou Estratégia Nacional de Educação Financeira, cujo projeto piloto foi implementado em mais de quatrocentas escolas do país em 2010, e que mostrou resultados bastante satisfatórios e animadores, conforme análise realizada pelo Banco Mundial (2011). Segundo a instituição, a ENEF foi uma iniciativa das entidades e dos órgãos integrantes do Comitê de Regulação e Fiscalização dos Mercados Financeiros, de Capitais, de Seguros, de Previdência e Capitalização (COREMEC), formado pelo Banco Central do Brasil (BACEN), pela Comissão de Valores Mobiliários (CVM), pela Superintendência Nacional de Previdência Complementar (PREVIC) e pela Superintendência de Seguros Privados (SUSEP). O objetivo do projeto piloto da ENEF foi aperfeiçoar a compreensão a respeito dos produtos financeiros e o desenvolvimento de habilidades para melhorar a relação dos indivíduos com suas finanças, ajudando os alunos a enfrentarem os desafios cotidianos e a alcançarem a realização de seus sonhos a partir do uso adequado de ferramentas financeiras.

O estudo realizado pelo Banco Mundial (2011) a respeito dos resultados da ENEF e seu projeto piloto mostra que o ensino de educação financeira nas escolas afeta positivamente o conhecimento dos alunos sobre contextos econômicos, como o orçamento familiar e o índice de inflação do país. Além disso, o estudo constatou que a educação financeira também provocou mudanças comportamentais, não só nos jovens diretamente envolvidos, mas também em seus familiares: a conclusão foi que os pais se tornaram mais propensos a incluir os filhos nos processos de tomada de decisões financeiras e a discutir assuntos relacionados a dinheiro e orçamento familiar. Outra conclusão apresentada neste estudo, que reforça conceitos já apresentados pelo presente trabalho, foi que alunos com melhores condições socioeconômicas e também aqueles cujos pais trabalham no setor formal da economia apresentaram maior nível de alfabetização financeira, enquanto que os alunos com famílias pertencentes a grupos de baixa renda apresentaram níveis mais baixos de conhecimento. 
A Educação Financeira tem um papel fundamental ao desenvolver competências que permitem consumir, poupar e investir de forma responsável e consciente, propiciando uma base mais segura para o desenvolvimento do país. Tal desenvolvimento retorna para as pessoas sob a forma de serviços mais eficientes e eficazes por parte do Estado, numa relação saudável das partes com o todo.

O planejamento financeiro tem um objetivo muito maior do que simplesmente não ficar no vermelho. Mais importante do que conquistar um padrão de vida é mantê-lo, e é para isso que devemos planejar.

\subsubsection{Orçamento pessoal ou familiar}

Segundo Banco Central do Brasil (2013) o orçamento pode ser visto como uma ferramenta de planejamento financeiro pessoal que contribui para a realização de sonhos e projetos. Para que se tenha um bom planejamento, é necessário saber aonde se quer chegar; é necessário internalizar a visão de futuro trazida pela perspectiva de realização do projeto e estabelecer metas claras e objetivas, as quais geralmente precisam de recursos financeiros para que sejam alcançadas ou para que ajudem a atingir objetivos maiores. Por isso, é importante que toda movimentação de recursos financeiros, incluindo todas as receitas (rendas), todas as despesas (gastos) e todos os investimentos, esteja anotada e organizada.

Claro que a pessoa pode eventualmente querer comprar alguma coisa a mais, ou perceber que esqueceu algo importante, ou, ainda, resolver voltar das compras com um presente para alguém em casa. O orçamento não é uma camisa de força, e sim um guia para ajudar você a atingir seus objetivos de vida. O mais importante é que se tenha consciência das ações.

Se o dinheiro está saindo, tem que entrar de algum lugar. Esse dinheiro que entra é a receita; o dinheiro que sai corresponde às despesas. Um orçamento pessoal ou familiar é uma forma de planejamento financeiro. Geralmente utiliza-se uma tabela que tem em uma de suas colunas as receitas e na outra, as despesas.

Todas as pessoas estão sujeitas a imprevistos, por isso é interessante fazer com que as receitas superem as despesas no orçamento familiar, por meio de planejamento e disciplina, para que se possa poupar todo mês e investir, por exemplo, em uma conta poupança. Assim haverá provisões para atender às despesas previstas, incluindo as que têm um determinado fim, como comprar uma geladeira nova ou criar reservas para os imprevistos. Caso a reserva financeira não seja suficiente para cobrir uma despesa eventual ou extraordinária pode ser necessário recorrer a empréstimos.

Em uma família, as pessoas que produzem a receita se esforçam para fazer com que ela cubra as despesas. Para gastar, é preciso ter. 


\section{Como elaborar um orçamento}

O Banco Central do Brasil (2013) sugere um método que consiste em quatro etapas: planejamento, registro, agrupamento e avaliação.

\section{$1^{\mathrm{a}}$ etapa: Planejamento}

O processo de planejamento consiste em estimar as receitas e as despesas do período. Para isso, você pode utilizar sua rotina passada, elencando as receitas e as despesas passadas e usando-as como base para prever as receitas e as despesas futuras.

Veja, na sequência, algumas sugestões para auxiliá-lo nesta etapa.

A princípio diferencie as receitas e as despesas fixas das variáveis:

- Receitas fixas - são aquelas com presença constante no orçamento, e seu valor não costuma variar significativamente em curto prazo. Por exemplo: salários, bolsas de auxílio, recebimento de aluguéis, pensões e aposentadorias. Essa é a receita estável. Em muitas famílias é considerada a receita com a qual se pode contar, "o dinheiro certo" de todo mês.

- Receitas variáveis - são aquelas que não estão presentes para as despesas de todos os dias. Podem ser esperadas ou inesperadas e têm valor ou mesmo presença inconstante no orçamento. Por exemplo, comissões de vendas, gorjetas, gratificações, palestras remuneradas, serviços extras nas horas vagas, etc. O décimo-terceiro salário dos assalariados ou empregos temporários na alta temporada turística são exemplos de receitas variáveis previsíveis. Prêmios e heranças são exemplos de receitas variáveis inesperadas.

- Despesas fixas - são aquelas que têm presença constante no orçamento e cujo valor não costuma sofrer alterações. Exemplos: Aluguel, prestação do financiamento imobiliário, mensalidade escolar, condomínio.

- Despesas variáveis - são aquelas que têm presença constante no orçamento, porém podem sofrer mudanças de valor significativas de um mês para o outro. Elas podem ser obrigatórias: alimentação, vestuário, transporte ou não obrigatórias: celular, produtos de beleza, viagens.

\section{$2^{\text {a }}$ etapa: Registro}

É necessário anotar, de preferência diariamente, para evitar esquecimentos, todas as receitas e despesas.

Para isso, citamos algumas sugestões: 
- Anote todos os gastos. Pode ser em uma caderneta, em uma agenda, no celular, no computador, etc.

- Confira os extratos bancários e as faturas de cartões de crédito;

- Guarde as notas fiscais e os recibos de pagamento;

- Guarde os comprovantes de utilização de cartões (débito/crédito);

- Diferencie as várias formas de pagamentos e desembolsos, separando-as em dinheiro, débito e crédito.

\section{$3^{\text {a }}$ etapa: Agrupamento}

Você perceberá que, com o tempo, as anotações serão muitas. Para que você as entenda melhor, agrupe-as conforme alguma característica similar. Por exemplo: despesa com alimentação, com habitação, com transporte, com lazer, etc. Essa não é a única forma de agrupar as despesas.

Você pode utilizar outras formas de agrupamento que sejam mais adequadas à sua realidade. O agrupamento facilita a verificação da parcela do salário ou da renda que é gasta em cada grupo de itens, além de auxiliar com os ajustes ou cortes que eventualmente sejam necessários.

\section{$4^{\mathrm{a}}$ etapa: Avaliação}

Nesta etapa, avalia-se como suas finanças se comportaram e irá agir, corretiva e preventivamente, para que seu salário e sua renda proporcionem o máximo de benefícios, conforto e qualidade de vida.

Avaliar significa refletir. Portanto, sugerimos as seguintes reflexões.

- O balanço de seu orçamento foi superavitário, neutro ou deficitário? Ou seja, você gastou menos, o mesmo ou mais do que recebeu?

- Quais são seus sonhos e suas metas financeiras? São compatíveis com o seu orçamento? Tem separado recursos financeiros para realizá-los?

- É possível reduzir gastos desnecessários? Observe os pequenos gastos, pois a soma de muitos "poucos" pode ser bem relevante.

- É possível aumentar as receitas? 


\subsubsection{Entendendo sua gestão orçamentária}

Segundo Martins (2004), à medida que for organizando as informações sobre seus ganhos e seus gastos, e registrando no seu orçamento, você começará a perceber a maneira como a sua renda é gasta. É importante que você examine item a item em cada uma das categorias e reflita sobre o que está gastando.

Caso esteja consumindo uma parte relativamente elevada da sua renda no grupo das despesas variáveis não obrigatórias (celular, produtos de beleza, viagens, etc.), abre-se aí uma oportunidade para redução de gastos sem sacrifícios substanciais do padrão de vida de sua família, com a hipótese de fazer cortes de forma a melhorar o saldo de caixa.

\section{Estabelecendo metas de poupança e gerenciando seus gastos}

Segundo Martins (2004), qualquer que seja a situação financeira da família é importante estabelecer metas de poupança e gerenciar os gastos. A única forma de atingir a meta de poupança é pôr as contas no papel e monitorar os gastos com base no fluxo de caixa projetado.

Gerenciar o orçamento familiar é mais ou menos como comandar um navio: conhecido o rumo, é necessário acompanhar os gastos e tomar as decisões financeiras que permitem cumprir as metas estabelecidas. Muitas vezes você chegará na metade do mês e perceberá que já gastou, em determinados itens, toda a conta do mês; aí é a hora de pensar, planejar e agir, impondo-se disciplina e, até mesmo, sacrifícios.

A arte de cortar gastos exige que se observe o grau de importância de cada despesa, segundo critérios da própria família. Por exemplo, não faz sentido diminuir as despesas com plano de saúde se houver possibilidade de fazer o mesmo na conta de gastos com lazer.

Suponha que você tenha decidido reduzir em $20 \%$ os gastos mensais de sua família. Você precisa de um método para não perder tempo com o que não dá para ser feito. Por exemplo, numa família com quatro pessoas no qual todas tem celular pós pago, a despesa nesse item pode passar da metade do valor do aluguel. Soa estranho imaginar redução no aluguel, que é uma despesa obrigatória fixa, em detrimento de redução na conta do celular, que pode ser reduzida sem muito sacrifício.

Segundo Banco Central do Brasil (2013), o uso do dinheiro muitas vezes envolve não apenas você mesmo, mas também sua família mais próxima. Não deixe de conversar com eles e traçar planos em comum, de modo a todos estarem compromissados com o que for definido no planejamento orçamentário.

Gerenciar os gastos significa envolver todos os membros de sua família, deixando claro qual é a renda familiar e quais são os gastos. A recomendação é simples: organize e tome as decisões em equipe. 


\subsubsection{Uso do crédito}

Segundo Comitê Nacional de Educação Financeira (CONEF 2013) as pessoas com orçamentos deficitários, ou seja, aquelas com despesas maiores que receitas, quando não conseguem equilibrar seus orçamentos, na maioria das vezes tomam dinheiro emprestado. No Brasil, muitas pessoas conseguem pegar emprestado o dinheiro de que precisam com seus familiares, mas quando isso não é possível, podem recorrer ao sistema financeiro. Elas então tomam crédito em instituições financeiras, muitas vezes em bancos. Mas há um preço para isso: a taxa de juros.

Segundo Banco Central do Brasil (2013), o crédito é uma fonte adicional de recursos que não são seus, mas obtidos de terceiros (bancos, financeiras, cooperativas de crédito e outros), que possibilita a antecipação do consumo para a aquisição de bens ou contratação de serviços. Existem várias modalidades de crédito. Por exemplo: limite do cheque especial, cartão de crédito, empréstimos, financiamentos imobiliários ou de veículos, compra a prazo em lojas comerciais etc.

É muito importante para sua vida financeira saber escolher a modalidade de crédito mais adequada para cada situação. Com a devida compreensão dos custos envolvidos nas operações de crédito, é mais fácil o uso do crédito de forma consciente.

Seguem vantagens e desvantagens para o tomador do crédito:

\section{Vantagens}

- Antecipar consumo - Muitas vezes, precisamos comprar um produto ou contratar um serviço, porém não dispomos de recursos suficientes. O crédito nos possibilita resolver essa situação.

- Atender a emergências - Imprevistos acontecem com frequência: acidente com o veículo, serviço emergencial na residência, alguém da família com problema de saúde quando não estamos financeiramente preparados. O uso do crédito pode ser a saída nesse momento.

- Aproveitar oportunidades - Boas oportunidades para fechar um negócio ou fazer uma compra às vezes acontecem e nem sempre, naquele momento, temos condições financeiras para aproveitá-las. Faça as contas, levando em conta o custo do crédito.

Desvantagens

- Custo da antecipação do consumo com o uso do crédito implica pagamento de juros - Ao anteciparmos a compra de um produto ou a contratação de um serviço sem a devida disponibilidade financeira, usaremos um dinheiro que não é nosso, portanto pagaremos juros por essa operação. Esse é o custo da antecipação. 
- Risco de endividamento excessivo - O uso inadequado do crédito pode levar ao endividamento excessivo e comprometer toda a sua vida financeira, podendo acarretar descontrole emocional, problemas de saúde e, até mesmo, desestruturação familiar. Assim, é importante refletir antes de tomar crédito e não o utilizar de forma indiscriminada.

- Limite de consumo futuro - Outra desvantagem de tomar crédito consiste em limitar o consumo futuro. Essa desvantagem é quase automática, uma vez que o crédito tomado hoje tem de ser pago no futuro, reduzindo, portanto, as disponibilidades financeiras futuras para o consumo.

\section{Tipos de empréstimos}

Alguns empréstimos são mais caros do que outros, pois o preço do empréstimo é formado como o preço de qualquer outro produto. Se um tênis custar R $\$ 200,00$, este preço foi formado por uma série de fatores. Existe o custo da matéria-prima para fazer o tênis (borracha, tecidos, fios de nylon, espuma, tinta, etc.), os impostos que a fábrica tem que pagar para o governo, o transporte do tênis até a loja, o salário do vendedor, os custos do aluguel da loja, da luz, água etc., e tem também o lucro do lojista. Esses e outros fatores ligados à produção, mais o lucro que o lojista quer ter com a venda, formaram o preço do tênis de $\mathrm{R} \$ 200,00$.

Segundo CONEF (2013), no caso das instituições financeiras, o preço do empréstimo será dado pelos juros e outros encargos. Os fatores que mais impactam nos juros são o risco de crédito e o lucro. Que risco? O de inadimplência, ou seja, o de não receber o dinheiro de volta. Que lucro? O lucro que as instituições querem obter com a "venda" do dinheiro, ou seja, o lucro que querem ter com o empréstimo. Existem também outros custos, como os impostos a serem pagos para o governo.

Como as instituições financeiras (bancos, financeiras, caixas econômicas, etc.) são empresas com fins lucrativos, elas pagam impostos como qualquer outra empresa. Outro custo importante são os depósitos compulsórios que elas têm que efetuar junto ao Banco Central. Portanto, assim como na formação do preço do tênis, existem vários fatores ligados ao custo do negócio que, somados ao lucro que a instituição financeira deseja ter com o empréstimo, acabam por formar os juros cobrados da pessoa que pega o dinheiro emprestado.

Como saber qual instituição financeira está oferecendo o empréstimo ou financiamento com melhores condições?

Comparar o preço de um tênis em várias lojas é fácil, pois o produto é visível e o preço é um número em todas as lojas. Mas no caso dos empréstimos e financiamentos existe uma série de números (valor emprestado, juros, taxas, valor das prestações, prazo para pagamento, etc.) que variam muito dependendo da instituição financeira, deixando tudo muito confuso. 
Para sanar essa confusão existe o chamado Custo Efetivo Total, ou simplesmente CET.

Segundo CONEF (2013), o CET é expresso na forma de taxa percentual anual, que diz quanto efetivamente custa um empréstimo ou financiamento, incluindo não só os juros, mas também tarifas, impostos e outros encargos cobrados do cliente. A vantagem do CET é que ele permite comparar o que duas ou mais instituições financeiras estão oferecendo e saber qual cobra menos pelo empréstimo. Dependendo dos encargos cobrados por uma instituição em um empréstimo, o CET pode acabar sendo maior que o de outro banco, mesmo tendo uma taxa de juros menor.

Para que você utilize o CET de modo correto, é fundamental que as condições dos empréstimos pesquisados sejam iguais.

Por exemplo, se em uma instituição financeira você simular um empréstimo de $\mathrm{R} \$ 1.000,00$ para pagar em 24 meses e em outra você simular um empréstimo de $\mathrm{R} \$ 1.000,00$ para pagar em 36 meses, o CET não poderá ser utilizado para compará-los, pois as condições dos empréstimos são diferentes. Seria como você comparar o preço de dois tênis diferentes. Por lei as instituições financeiras são obrigadas por lei a fornecer o CET.

Por exemplo, suponha um financiamento nas seguintes condições:

Valor financiado: $\mathrm{R} \$ 1.000,00$;

Taxa de juros: $12 \%$ a.a;

Prazo da operação: 5 meses;

Prestação mensal: $\mathrm{R} \$ 205,73$

Considere ainda que seja descontado do crédito o valor de $\mathrm{R} \$ 60,00$, referente à tarifa de confecção de cadastro para início de relacionamento e cobrança de IOF. O valor líquido recebido pelo cliente é de $\mathrm{R} \$ 940,00$.

Nessas condições, o CET é de 43,93\% a.a., percentual que supera a taxa de juros divulgada na operação, que foi de $12 \%$ a.a.

Então, sempre que se contrai um empréstimo em uma instituição financeira, o valor a ser devolvido já será maior do que o emprestado inicialmente (o principal). Quanto mais tempo se demora a pagar de volta, maior será o valor que terá de ser pago. Quem pega empréstimo paga juros e quem aplica dinheiro em investimentos nos bancos recebe juros. Então ter juros altos é ruim para tomadores de empréstimo e bom para quem investe dinheiro. Em termos simples, a taxa de juros é o preço do dinheiro. 


\section{Taxa nominal de juros}

Suponha uma aplicação financeira de $\mathrm{R} \$ 200,00$. Para que haja a concordância em deixar o dinheiro no banco, ele tem de lhe oferecer alguma compensação. O banco lhe paga então juros sobre o dinheiro que foi deixado com ele por esse tempo. $\mathrm{O}$ investimento é um empréstimo feito ao banco.

Os juros são expressos em porcentagem do valor investido ou emprestado. Voltando ao exemplo, imagine que ao aplicar os $\mathrm{R} \$ 200,00$ no banco, esse valor renda juros de $10 \%$ ao fim do período. Isso quer dizer que ao final da aplicação o montante será de $\mathrm{R} \$ 220,00$.

Mas não basta ter o percentual. Também é preciso saber o período de tempo a que se refere esse percentual. Ganhar $10 \%$ ao ano é muito diferente de ganhar $10 \%$ ao mês para um mesmo dinheiro investido. A taxa que o banco paga pelo investimento é a taxa nominal de juros.

\section{Taxa de juros real}

Suponha a aplicação em um investimento que pagou $10 \%$ ao ano. Ao final de dois anos os $\mathrm{R} \$ 200,00$ tornaram-se $\mathrm{R} \$ 242,00$.

Dividindo o valor final pelo inicial $(\mathrm{R} \$ 242,00 / \mathrm{R} \$ 200,00)$ o rendimento total foi de $21 \%$. Mas esse rendimento não garante que, se for usar o dinheiro, possa aumentar suas compras em 21\%. Nesses dois anos em que o dinheiro ficou investido, os preços dos produtos subiram. Houve inflação. Para saber quanto o investimento rendeu em termo de compras de produtos é preciso calcular a taxa de juros real, que é a taxa nominal de juros descontada a taxa de inflação.

Nesse exemplo, se a inflação fosse de $5 \%$ ao ano, a taxa real de juros seria de $9,75 \%$ nos dois anos. Isso quer dizer que só poderá aumentar o volume de suas compras em $9,75 \%$. Em outras palavras, ter hoje $\mathrm{R} \$ 242,00$ na mão seria o mesmo que ter $\mathrm{R} \$$ 219,50 dois anos atrás. Uma parte do investimento foi corroída pela inflação.

Resumindo, o rendimento nominal é aquele que de fato vai aparecer na sua poupança. O rendimento real é aquele que dá o verdadeiro aumento da sua capacidade de fazer compras.

\section{Risco e retorno}

Segundo CONEF (2013), o risco é a possibilidade de ocorrer algo que não estava previsto. Nesse caso, o retorno obtido será diferente do esperado.

Os investimentos seguros pagam taxas mais baixas porque é pequeno o risco de que o retorno obtido na aplicação seja diferente daquilo que é esperado. Esse é o caso da 
poupança.

Os investimentos mais arriscados, em que há chance de perda de dinheiro, pagam mais. Quanto maior o risco, maior o retorno.

Portanto, desconfie de ofertas em que o risco é baixo e o retorno é alto.

No Brasil, as taxas de juros costumam ser mais altas para o cheque especial e o cartão de crédito, que chega a três dígitos (exemplos: 140\%, 320\% ao ano). Essa taxa é muito maior do que a cobrada pelo dinheiro emprestado para se comprar alguma coisa concreta, como um carro. A razão alegada é que, diferentemente de um carro, que pode ser penhorado pelo banco, o empréstimo para o cheque especial não tem nenhuma garantia material. Ou seja, o banco não tem como recuperar o dinheiro que empresta caso a pessoa não o pague de volta. Assim, o risco de emprestar o dinheiro é alto, então a taxa de juros cobrada por esse serviço também é alta. Outros fatores que compõem a taxa de juros são os impostos e os lucros das instituições financeiras.

\section{Ciladas com cartão ou cheque}

Não são poucas as pessoas que se veem atrapalhadas com dívidas de cartão de crédito ou cheque especial. Muitas vezes elas nem entendem direito como se meteram em tamanha encrenca.

Ao usar o cartão de crédito, você está apenas adiando um pagamento à vista. Por isso é preciso ter controle suficiente para pagar a fatura integralmente, evitando os juros. E lembre-se também que cartões de crédito acarretam uma despesa independente de qualquer compra: suas anuidades.

Segundo CONEF (2013), o uso de cartão ou cheque estimula a gastar mais do que gastaríamos se estivéssemos usando dinheiro vivo - isso já foi verificado em várias pesquisas.

Existem pessoas que não conseguem se controlar. Para essas, o melhor é não usar mesmo o cartão de crédito ou débito. Se elas estão na rua com o cartão e não conseguem se controlar na hora da compra, então podem se controlar um pouco mais antes de sair de casa e se expor às tentações da compra.

O cartão pode funcionar melhor para compras planejadas. No entanto, quando acontece algum imprevisto e você não possui um dinheiro poupado para arcar com essa despesa, então é possível usar o cartão para fazer a compra.

No caso de não pagamento da fatura, a dívida com o cartão de crédito aumenta muito rapidamente, porque os juros são altos. Veja alguns cuidados necessários ao usar o cartão:

- Verifique regularmente a fatura do seu cartão para não perder o controle dos seus gastos.

- Inclua os pagamentos feitos com cartão no orçamento do mês atual ou do mês 
seguinte, dependendo da data do vencimento. O que não pode é deixar de somar essas despesas com as demais.

- O cartão de crédito não lhe dá mais dinheiro. Só gaste o valor que você consegue pagar porque você terá de pagar em uma única data a soma de todas as despesas pagas com ele ao longo do mês. Podem ser várias pequenas quantias ou uma única grande despesa, mas o fato é que tudo se concentrará em uma mesma data de pagamento.

- Cuidado com a apresentação da fatura: as empresas costumam destacar o valor mínimo - às vezes até em negrito. Muitas pessoas acham que aquele é o valor devido no mês, pagam só o mínimo e acabam financiando o resto. Isso implica juros, ou seja, o valor que você não pagou naquele mês ficará acrescido de juros no mês seguinte. A despesa aumenta! Pague o valor total da fatura, sem cair na tentação de realizar apenas o pagamento mínimo escrito na fatura do cartão.

- Se uma despesa for de fato necessária e levar alguns meses para ser paga, faça o planejamento desse pagamento, incluindo os juros que incidem sobre o valor não pago a cada mês e verificando outras formas de crédito mais baratas.

A seguir citamos vantagens e desvantagens ao usar o cartão de crédito.

Vantagens:

- Praticidade

- Acumulo de "pontos" ou "milhas", que podem ser trocados por prêmios.

- Extrato consolidado

- Mais tempo para pagar a conta

- Pagamento em data única

- Uso em emergências

Desvantagens:

- Tendência a gastar demais

- Custo de anuidade

- Tentação de endividar-se e/ou sair do orçamento

- Clonagem

- Alta taxa de juros 
Uma dívida contraída de forma impensada pode ser trocada por outra que custe menos. Há pessoas que preferem quitar uma dívida cara (como a do cheque especial) contraindo outra menos custosa (empréstimo consignado). O valor da dívida pode ser o mesmo, mas as condições (juros, prazo etc.) podem fazer uma grande diferença no valor das parcelas. Mas lembre-se: esse é um passo intermediário para voltar ao equilíbrio ou pelo menos a uma situação financeiramente mais confortável. Ainda existirá uma dívida para quitar e será necessário rever suas receitas e despesas!

\subsubsection{Como sair das dívidas}

Segundo Banco Central do Brasil (2013), seguem os passos para sair de uma situação de endividamento.

\section{$1^{\circ}$ passo: Tomar consciência da situação}

Ter a consciência de que se encontra em uma condição de endividamento excessivo e de que é preciso resolver essa situação é um passo fundamental para a saída do endividamento.

\section{$2^{\circ}$ passo: Mapear as dívidas}

Após tomar consciência do endividamento e de ter a certeza de que quer sair dessa situação, é importante conhecer o real tamanho do problema. E conhecer as dívidas é exatamente mapear detalhadamente as informações importantes: os valores das dívidas, os prazos para pagamento e as taxas de juros que está pagando.

\section{$3^{\circ}$ passo: Não fazer novas dívidas}

Esse é o momento de reorganização da vida financeira e fazer dívidas nessa hora é realimentar um ciclo negativo, dificultando a saída do endividamento. Não fazer novas dívidas é, então, uma prioridade, um desafio a ser vencido por quem se encontra endividado e realmente quer sair do endividamento.

\section{$4^{\circ}$ passo: Renegociar as dívidas}

Negociar condições mais vantajosas para o pagamento das dívidas é outro aspecto fundamental para a saída do endividamento. Essa é a hora de procurar trocar dívidas que pagam juros elevados por dívidas com juros menores. Negociar os prazos também pode ajudar na reorganização financeira do endividado. 


\section{$5^{\circ}$ passo: Reduzir gastos}

Outra ação imprescindível para a saída do endividamento é o corte de gastos. Sobre o assunto, vale a pena refletir sobre os três tipos de gastos.

1) Necessários: são os gastos considerados imprescindíveis. Estão ligados às necessidades. Como exemplo citamos alimentação, moradia e vestuário. Neste caso buscaremos otimizar, procurando alternativas.

2) Supérfluos: são os gastos que geram bem-estar e estão ligados mais aos desejos que às necessidades. Como exemplo citamos restaurantes, TV a cabo e roupas de marca. Esses devem ser reduzidos drasticamente ou eliminados.

3) Desperdícios: são os gastos que não geram bem-estar nem estão ligados às necessidades ou aos desejos. Como exemplo citamos multas, pagar por algo e não usar, esquecer luz acesa ou a torneira aberta. Os desperdícios devem ser eliminados por completo.

\section{$6^{\circ}$ passo: Gerar renda extra}

Muitas vezes o orçamento já está no limite suportável e, ainda assim, encontra-se deficitário.

Adicionalmente à minimização dos nossos gastos, podemos avaliar uma alternativa de ampliar a nossa renda. Identifique áreas e serviços em que tenha habilidades, para gerar renda extra e complementar o seu orçamento.

\subsubsection{Investindo seus recursos}

Segundo Banco Central do Brasil (2013), ao poupar você acumula valores financeiros no presente para serem utilizados no futuro. Os valores poupados no presente e investidos durante um, dois ou mais anos poderão fazer uma diferença significativa na qualidade de vida do poupador no futuro.

Assim, são vários os motivos para poupar: precaver-se diante de situações inesperadas, preparar para aposentar-se, realizar sonhos, entre outros.

Segundo Martins (2004), de uma maneira geral, as opções que nós temos para aplicar os recursos poupados ao longo da vida se resumem a quatro grupos básicos, que são os seguintes:

1 - Imóveis;

2 - Títulos públicos de Renda Fixa;

3 - Títulos privados de Renda Fixa; 
4 - Ações.

Existiria ainda uma quinta opção que seria abrir sua própria empresa, que não é o foco do trabalho.

Mas antes de começar a falar sobre os investimentos propriamente ditos existem três conceitos importantes para quem pensa em investir: segurança, rentabilidade e liquidez.

Quando um banco faz uma operação de empréstimo a uma empresa, ele pede garantias reais, pois ele quer ter a certeza de que, se a empresa quebrar, essa garantia sirva para pagar o empréstimo.

Quando você compra ações de uma grande empresa você sabe que por trás daquele papel há uma empresa com uma estrutura de ativos reais, produtos conhecidos e uma história de sucesso. As garantias reais são um fator de segurança da operação financeira.

Rentabilidade é a outra palavra obrigatória sobre toda decisão de investimento financeiro. Ela diz respeito aos ganhos que fluirão para o bolso do investidor.

Há uma relação inversa entre segurança e rentabilidade: quanto mais segura a operação, menor a rentabilidade e vice-versa.

O investidor não tem alternativa: ele tem que decidir se quer mais segurança ou mais lucro, Investidor que deseja ter risco zero tem de suportar baixas taxas de rendimento.

Liquidez diz respeito à capacidade de transformação do ativo em dinheiro. Os investidores de imóveis devem ter consciência que eles são de baixa liquidez, ou seja, em função da dificuldade e demora de vendê-los. Já os investimentos financeiros podem ser transformados em dinheiro mais rapidamente.

\section{Imóveis}

O investimento em imóveis é um dos mais tradicionais e sempre foi o porto seguro daqueles que não acreditam muito no governo nem gostam de ativos financeiros. Para a maioria dos investidores em imóveis, especialmente os que compraram unidades residenciais para locação, os rendimentos dos investimentos neste momento não são tão bons se comparados com os rendimentos dos ativos financeiros, pois além dos imóveis não apresentarem grande valorização, os aluguéis residenciais são um tipo de renda extremamente problemático pelo risco de calote por parte do locador.

Cabe salientar que o investimento em imóveis exige definição clara de objetivos, paciência, disciplina e conhecimento especializado, sobretudo porque se trata de ativos de baixa liquidez. 


\section{Títulos Públicos de Renda Fixa}

O brasileiro tem uma relação ambígua com o governo do seu país. Ao mesmo tempo em que vivemos desconfiando dos governos e governantes por causa de calotes e pacotes econômicos, entregamos nosso dinheiro para financiar a dívida pública.

Historicamente, os títulos públicos do governo brasileiro sempre foram honrados e representam um investimento de baixíssimo risco.

Em 2003 o governo brasileiro passou a divulgar um tipo de investimento chamado "Tesouro Direto", pelo qual a pessoa pode adquirir títulos públicos federais fora dos fundos de investimentos administrados pelos bancos; ou seja, pode comprar o título público diretamente, livrando-se da taxa de administração que os bancos cobram nos fundos. Essa é uma opção interessante, segura, de boa rentabilidade e alta liquidez.

Cabe salientar que os investimentos em títulos públicos federais incidem imposto de renda sobre os rendimentos nas vendas, nos vencimentos de títulos e no pagamento de cupons ocorridos. Esse é cobrado de acordo com a Lei $\mathrm{n}^{\mathrm{o}} 11.033$, conforme tabela regressiva do IR seguinte:

Alíquota de 22,5\% - até 180 dias após a aplicação;

Alíquota de $20 \%$ - de 181 até 360 dias após a aplicação;

Alíquota de 17,5\% - de 361 até 720 dias após a aplicação;

Alíquota de $15 \%$ - em prazo superior a 720 dias da aplicação.

Entre as opções de títulos públicos, vale a pena destacar os seguintes:

\section{LTN - Letras do Tesouro Nacional}

São títulos com rentabilidade pré-definida (pré-fixados), pois a taxa de juros é fixa e conhecida no momento da compra. É um investimento bom para quem não vai precisar do dinheiro antes do vencimento do título e gosta de saber antecipadamente quanto vai ganhar.

\section{LFT - Letras Financeiras do Tesouro Nacional}

Esses títulos tem rentabilidade calculada diariamente pela taxa básica de juros do Banco Central, conhecida como taxa SELIC, que é a taxa média das operações diárias com títulos públicos registradas no Sistema Especial de Liquidação e Custódia. Este tipo de investimento não diz antecipadamente qual será o percentual de ganho, mas tem vantagem de garantir que os juros pagos seguirão os rumos da taxa de juros básica do país. Se os juros subirem, o investidor sabe que seu investimento será beneficiado; se os juros caírem, o investidor terá de se contentar com juros menores. Mas vale lembrar que os juros caem quando a inflação diminui e a economia do país apresenta bons sinais de desempenho. 


\section{NTN-C - Notas do Tesouro Nacional - Série C}

São títulos que dão ao investidor uma taxa de juros definida no momento da compra mais uma taxa correspondente à inflação futura calculada pelo IGP-M (Índice Geral de Preços do Mercado). Este tipo de investimento tem a vantagem de deixar claro ao investidor qual taxa de juros real ele vai ganhar qualquer que seja a inflação, já que esta será reposta pela aplicação do IGP-M; é um bom investimento para quem tem medo dos rumos que a inflação pode tomar.

\section{NTN-B - Notas do Tesouro Nacional - Série B}

São títulos que dão ao investidor uma dada taxa de juros definida no momento da compra mais uma taxa correspondente à inflação futura calculada pelo IPCA (Índice de Preços ao Consumidor Amplo). Este tipo de investimento é exatamente igual às NTN-C, mudando apenas o índice de inflação que será utilizado para remunerar o papel. A diferença é que, enquanto o IGP-M é um índice geral de preços, o IPCA é um índice de preços que reflete a elevação dos preços dos bens consumidos por famílias com renda de até quarenta salários mínimos.

\section{Títulos Privados de Renda Fixa}

Assim como o governo emite títulos para captar recursos da sociedade destinados a financiar seus gastos e a rolagem de sua dívida, as empresas estatais e privadas também o fazem, destacando-se as debêntures e os títulos bancários.

\section{Debêntures}

Se a Petrobrás necessitar de dinheiro para as suas atividades e não possuir reservas em caixa, ela pode emitir títulos privados e vendê-los a investidores que se disponham a emprestar seu dinheiro a ela. Da mesma forma, qualquer empresa com um bom histórico e registrada nos órgãos competentes, a exemplo da CVM (Comissão de Valores Mobiliários) tem a possibilidade de se financiar tomando dinheiro do público, pagando juros pré-fixados ou pós-fixados.

Na prática, as empresas que desejam tomar dinheiro emprestado do público procuram um banco, o qual se encarrega de organizar a emissão dos papéis e a venda no mercado. Esses papéis podem ser vendidos a um fundo de investimento, que é um agrupamento de pessoas que colocam seu dinheiro em um mesmo balaio para ser aplicado em títulos públicos e/ou privados. Os bancos são os organizadores e administradores dos fundos de investimento; eles procuram as pessoas, formam os fundos e fazem as aplicações em nome dos quotistas, geralmente emprestando ao governo e às empresas.

Os Fundos de Investimento são condomínios que reúnem recursos de um conjunto de investidores com o objetivo de obter ganhos financeiros a partir da aquisição de uma 
carteira de títulos ou valores mobiliários. Os fundos tornam possível a diversificação dos investimentos, disponibilizando alternativas com as mais variadas relações entre risco e retorno. A incidência de Imposto de Renda ocorre semestralmente ("come-cotas") ou no momento no resgate (de acordo com a Tabela Regressiva).

Quando um banco organiza um fundo de investimentos e você se torna quotista desse fundo, o banco atua como mero administrador do seu dinheiro; se o banco quebrar, o seu dinheiro estará garantido pelos títulos que foram comprados pelo fundo do qual você participa.

\section{Títulos Bancários}

Assim como você pode emprestar o seu dinheiro para uma empresa industrial ou comercial, por meio do seu fundo de investimento, você também pode emprestar dinheiro para um banco. Dentre os investimentos bancários de renda fixa destacamos: a poupança, o CDB (Certificado de Depósito Bancário), o RDB (Recibos de Depósito Bancário), as LCI (Letras de Crédito Imobiliário) e as LCA (Letras de Crédito do Agronegócio). Em todos esses casos, você estará emprestando dinheiro ao banco, que o usa para emprestar às pessoas, às empresas e para o governo. Nesse caso, você corre o risco do banco; ou seja, se o banco quebrar, você pode não receber o seu dinheiro de volta caso ultrapasse o valor assegurado pelo FGC (Fundo Garantidor de Crédito), que no momento é fixado em $\mathrm{R} \$ 250$ mil.

\section{Poupança}

Uma das aplicações financeiras mais tradicionais do mercado. A regra da poupança determina apenas que quando a taxa SELIC ficar igual ou menor que 8,5\% ao ano, o rendimento da poupança passará a ser de $70 \%$ da taxa SELIC + TR. Esta regra é válida somente para depósitos realizados a partir de 04 de maio de 2012.

Os depósitos realizados antes de dia 04 de maio de 2012 não sofrem nenhuma alteração e tem garantido o rendimento fixo de $0,5 \%$ ao mês $+\mathrm{TR}$, pelo tempo que forem mantidos em poupança. Os rendimentos são creditados mensalmente, a cada dia-limite, não é descontado Imposto de Renda e a liquidez é imediata.

\section{$\mathrm{CDB} / \mathrm{RDB}$}

Os CDBs e RDBs são títulos emitidos pelos Bancos para a captação de recursos junto aos clientes, proporcionando-lhes rentabilidade durante um prazo previamente combinado, e segundo determinadas condições definidas no ato da aplicação. O CDB e o RDB são indicados como alternativa de investimento aos investidores que possuam conta corrente e que procuram alternativas de aplicação de baixo risco.

O CDB, sendo um título, pode ser negociado por meio de transferência. O RDB é inegociável e intransferível. O prazo mínimo varia, dependendo do tipo de remuneração 
contratada.

O CDB e o RDB são modalidades de aplicação com prazo, condições de remuneração e liquidez definidas no ato de cada aplicação. A incidência de Imposto de Renda ocorre somente no resgate ou no vencimento, conforme a Tabela Regressiva já citada acima. Dessa forma, quanto maior for o prazo que o investidor puder permanecer com os seus recursos investidos, maior será também a sua rentabilidade.

\section{LCI}

São títulos de crédito lastreados por crédito imobiliário, garantidos por hipoteca ou por alienação fiduciária de imóvel. As LCI foram criadas pela MP no 2.223, de 04/09/2001, convertida na Lei no 10.931, de 02/08/2004, como instrumento financeiro para captação de recursos para os financiamentos imobiliários.

A LCI geralmente é pré-fixada remunerada por um percentual do CDI, tem rentabilidade diária, é isenta de IRRF para pessoa física, e pode ser resgatada a partir de 90 dias, dependendo do contrato.

\section{LCA}

Títulos de crédito vinculados a direitos creditórios originários de negócios realizados entre produtores rurais, ou suas cooperativas, e terceiros, inclusive financiamentos ou empréstimos, relacionados com a produção, comercialização, beneficiamento ou industrialização de produtos ou insumos agropecuários ou de máquinas e implementos utilizados na atividade agropecuária.

A LCA geralmente é pré-fixada remunerada por um percentual do CDI, tem rentabilidade diária, é isenta de IRRF para pessoa física, e pode ser resgatada a partir de 90 dias, dependendo do contrato.

\section{Ações}

Ação é um pedaço do capital de uma empresa. Uma empresa que necessite de um capital social de $R \$ 100$ milhões pode dividir essa cifra em 20 milhões de ações ao valor de $\mathrm{R} \$ 5,00$ cada e vende-las para pessoas que ela não conhece. O instrumento para a venda é a Bolsa de Valores, onde são negociadas as ações das empresas. As pessoas que acreditam no futuro da empresa podem comprar as ações, entregando o seu dinheiro para que a organização invista em seus negócios.

A vantagem das ações de empresas é que existe um mercado secundário para elas; isto é, se algum tempo depois de adquirir as ações você quiser revendê-las, basta se dirigir à Bolsa de Valores e fazer a oferta. Na Bolsa, há pessoas em posição inversa à sua, aqueles que querem comprar ações da mesma empresa.

O preço das ações depende de dois fatores: da expectativa de lucros da empresa e do nível de procura das ações pela sociedade. 
O fato é que os detentores de ações com capital das empresas tem um mercado no qual podem transformá-las em dinheiro, vendendo os papéis aos preços vigentes. Se houver mais procura do que oferta, os preços sobem; se o volume de ações ofertadas à venda for maior do que o volume de ações procuradas para a compra, o preço cai.

O mercado de ações é um bom lugar para quem não necessita do dinheiro no curto prazo. A questão é que, em função de instabilidades econômicas, o mercado de ações passa por turbulências cíclicas, com os preços das ações mantendo-se deprimidos por períodos um tanto longos.

O possuidor de ações tem dois rendimentos advindos delas: os dividendos, representando a parte do lucro que a empresa distribui aos seus acionistas, e o ganho com a elevação do preço da ação.

No longo prazo, o investimento em ações tem sido bom negócio; mas não é mercado para amadores nem para o investidor que não tenha "estômago" para suportar movimentos bruscos de subida e descida do preço da ação.

\section{Previdência Complementar}

Numa era em que já não há mais dúvidas de que não dá para esperar que o governo cuide de você na velhice, na doença ou na invalidez, a preocupação com sua própria previdência é fundamental. Quando uma empresa compra uma máquina, ela sabe que um dia terá de substituir por outra máquina nova e mais moderna. Por isso, durante a "vida útil" da máquina a empresa vai calculando o seu desgaste, que é incluído no custo do produto, e vai formando uma reserva como "fundo de depreciação", usada para adquirir a máquina nova; nós também devemos fazer isso.

A tendência natural é que o ser humano fique velho, mais vulnerável às doenças e precisa cuidar para garantir uma renda na sua aposentadoria. Nosso corpo também sofre desgaste e a prudência recomenda que devemos fazer um fundo de reserva para quando decidirmos parar ou reduzir o ritmo de trabalho; a previdência complementar existe para isso. A previdência estatal, que é compulsória, provê um pequeno pecúlio aos aposentados; porém, não dá para confiar no governo nem na certeza de manutenção dos valores reais da aposentadoria pública. É melhor se prevenir, fazendo o seu plano de previdência privada.

Um plano de previdência nada mais é do que uma reserva financeira, formada por depósitos mensais feitos por você e que serão aplicados por uma instituição financeira, cujos rendimentos são incorporados ao capital, para garantir sua renda na aposentadoria. Ao se aposentar, você terá uma reserva que poderá ser sacada de várias formas: uma renda vitalícia, uma renda temporária ou um saque único; enfim, da maneira que você definir para o seu projeto de vida.

Segundo Halfeld (2008) os tipos de planos de previdência podem ser definidos por:

- Benefício definido: o valor a ser recebido, no futuro, é definido previamente, 
independentemente do resultado obtido pelo administrador de sua previdência. Representa menos riscos para o contribuinte e mais riscos para o administrador.

- Contribuição definida: o que você paga hoje está definido; o que você receberá não está combinado. Tudo depende da competência do administrador em gerenciar seus recursos.

Há três modalidades principais de aplicações dos recursos depositados no plano de previdência:

\section{Fundos soberanos}

Nestes, os recursos são aplicados integralmente em títulos públicos federais de renda fixa. Ou seja, o governo é o tomador do seu dinheiro, de forma que você tem a garantia do Tesouro Nacional. Esses fundos, por sua vez, sabem claramente quanto vão ganhar em rendimentos, pois a taxa de juros dos títulos públicos em questão é fixada; é uma aplicação de baixo risco e renda conhecida. Só haveria risco se acreditássemos que, por alguma razão, o governo um dia viesse a dar calote nos títulos, o que é improvável pois, no limite de uma crise financeira, o governo pode emitir moeda e pagar todas as suas dívidas.

\section{Fundos mistos de renda fixa}

Estes fundos aplicam seus recursos em títulos públicos e títulos privados de renda fixa. Os riscos aumentam um pouco, pois uma empresa privada, cujos títulos tenham sido comprados pelo seu fundo de previdência privada, pode ir à falência e você ter que amargar a perda daquela parte aplicada na empresa em questão. Por outro lado, caso a situação acima não ocorra, os rendimentos são superiores aos dos fundos soberanos.

\section{Fundos compostos}

São fundos que misturam aplicações em títulos públicos e privados com aplicações de renda variável. Basicamente, esses fundos podem aplicar até $49 \%$ dos seus recursos no mercado de ações, o que significa saber que você correrá riscos do sobe e desce do mercado de ações. 


\section{Capítulo 2}

\section{Matemática Financeira}

Este capítulo tem como foco alguns conceitos da Matemática Financeira que hoje são pouco trabalhados no ensino médio, desde a sua história até a aplicação na vida cotidiana do aluno. Este não pretende esgotar todos os conceitos em que possa se mostrar a matemática financeira, mas sugerir ao professor que ele pode fazer um trabalho diferente do que é proposto atualmente nos livros didáticos de ensino médio, que trazem apenas os conceitos de porcentagem, lucro e prejuízo, juros simples e compostos, despertando o interesse dos alunos pela disciplina.

Apesar de algumas demonstrações serem apresentadas, este não será o foco do trabalho, daremos importância às aplicações e aos cálculos. O uso de recursos tecnológicos (calculadora, softwares computacionais e/ou aplicativos para celulares) não serão desprezados; servirão como elementos necessários e estimulantes para a aprendizagem, uma parceria com o professor de informática, para a construção de planilhas eletrônicas, por exemplo, não esquecendo a necessidade de ensinar os cálculos tradicionais que representam um excelente exercício para o desenvolvimento do raciocínio; mas isso não impede que o professor use recursos avançados como uso de calculadora financeira, que aqui não terá ênfase devido ao seu raro aparecimento em uma escola de ensino médio.

\footnotetext{
É preciso ainda uma rápida reflexão sobre a relação entre Matemática e tecnologia. Embora seja comum, quando nos referimos às tecnologias ligadas à Matemática, tomarmos por base a informática e o uso de calculadoras, estes instrumentos, não obstante sua importância, de maneira alguma constituem o centro da questão.

O impacto da tecnologia na vida de cada indivíduo vai exigir competências que vão além do simples lidar com as máquinas. A velocidade do surgimento e renovação de saberes e de formas de fazer em todas as atividades humanas tornarão rapidamente ultrapassadas a maior parte das competências adquiridas por uma pessoa ao início de sua vida profissional.
}

Brasil, 2002

O material em questão versará sobre alguns tópicos da matemática financeira não 
propostas atualmente pelas referências bibliográficas do ensino regular, que hoje trabalham os assuntos porcentagem, cálculo de juros, descontos, variação percentual e taxas, além das progressões aritméticas e geométricas, porém, estes serão considerados imprescindíveis pois serão utilizados no decorrer do trabalho, procurando relacioná-los com o cotidiano das pessoas.

\subsection{Um pouco de história}

Segundo Gonçalves (2006), na época em que os homens viviam em comunidades restritas, tirando da natureza todos os produtos de que tinham necessidade, sem dúvida devia existir muito pouca comunicação entre as diversas sociedades. Mas com o desenvolvimento do artesanato e da cultura e em razão da desigual repartição dos diversos produtos naturais, a troca comercial mostrou-se pouco a pouco necessária.

O primeiro tipo de troca comercial foi o escambo, fórmula segundo a qual se trocam diretamente gêneros e mercadorias correspondentes a matérias primas ou a objetos de grande necessidade.

Com a intensificação das comunicações entre os diversos grupos e a importância cada vez maior das transações, a prática do escambo direto tornou-se bem rapidamente um problema, pois nem sempre era considerada conveniente pelas partes, podendo durar dias ou mesmo terminar sem troca quando as duas partes não se entendiam. Não se podiam mais trocar mercadorias segundo o capricho de tal ou qual indivíduo ou em virtude de um uso consagrado ao preço de intermináveis discussões.

Houve, portanto, a necessidade de um sistema relativamente estável de avaliações e de equivalências, fundado num princípio, dando a definição de algumas unidades ou padrões fixos. Nesse sistema é sempre possível estimar tal ou qual valor, não somente para as operações de caráter econômico, mas também para a regulamentação de problemas jurídicos importantes e, todas as espécies de produtos, matérias ou objetos utilitários serviram nessa ocasião.

A primeira unidade de escambo admitida na Grécia pré-helênica foi o boi. Não é por acaso que a palavra latina pecúnia, que quer dizer "fortuna, moeda, dinheiro", provém de pecus, que significa "gado, rebanho"; além disso, o sentido próprio da palavra pecúnia corresponde ao "ter em bois".

Em contrapartida, nas ilhas do Pacífico as mercadorias foram estimadas em colares de pérolas ou de conchas. Após um certo período, começou-se por trocar faixas de tecido por animais ou objetos. O tecido era a moeda; a unidade era o palmo da fita de duas vezes oitenta fios de largura.

Tais métodos apresentavam, contudo, sérias dificuldades de aplicação. Assim, à medida que o comércio se desenvolvia, os metais desempenharam um papel cada vez maior nas transações comerciais, vindo a tornar-se no fim das contas a "moeda de 
troca" preferida dos vendedores e compradores. E as avaliações das diversas mercadorias passaram a ser feitas quantitativamente pelo peso, cada uma delas referindo a uma espécie de peso-padrão relativo a um ou a outro metal.

Igualmente no Egito faraônico, os gêneros e as mercadorias foram frequentemente estimados e pagos em metal, que se dividia inicialmente em pepitas e palhetas. A avaliação era feita também sob a forma de lingotes ou de anéis, cujo valor se determinava em seguida pela pesagem.

Até aquele momento não somente tratamos de um simples escambo, mas também um verdadeiro sistema econômico. A partir de então, graças ao padrão de metal, as mercadorias passaram a não mais ser trocadas ao simples prazer dos contratantes ou segundo usos consagrados frequentemente arbitrários, mas em função de seu "justo preço".

Até então, tratava-se somente de introduzir nas transações e nos atos jurídicos uma espécie de peso-padrão, unidade de valor à qual o preço de cada uma das mercadorias ou ações consideradas era referido. Partindo desse princípio, o metal podia servir em toda ocasião como "salário", "multa" ou como "valor de troca", e no caso da "multa", algum tipo de cálculo de juros primário era utilizado para se obter um certo valor para a mesma.

Os juros e os impostos existem desde a época dos primeiros registros de civilizações existentes na Terra. Um dos primeiros indícios apareceu na Babilônia no ano de 2000 a.C.. Nas citações mais antigas, os juros eram pagos pelo uso de sementes ou de outras conveniências emprestadas. Muitas das práticas existentes originaram-se dos antigos costumes de empréstimo e devolução de sementes e de outros produtos agrícolas.

A História também revela que a ideia se tinha tornado tão bem estabelecida que já existia uma firma de banqueiros internacionais em 575 a.C., com os escritórios centrais na Babilônia. Sua renda era proveniente das altas taxas de juros cobradas pelo uso de seu dinheiro para o financiamento do comércio internacional. O juro não é apenas uma das nossas mais antigas aplicações da Matemática Financeira e Economia, mas também seus usos sofreram poucas mudanças através dos tempos.

Como em todas as instruções que tem existido por milhares de anos, algumas das práticas relativas a juros tem sido modificadas para satisfazerem às exigências atuais, mas alguns dos antigos costumes ainda persistem de tal modo que o seu uso nos dias atuais ainda envolve alguns procedimentos incômodos. Entretanto, devemos lembrar que todas as antigas práticas que ainda persistem foram inteiramente lógicas no tempo de sua origem. Por exemplo, quando as sementes eram emprestadas para a semeadura de uma certa área, era lógico esperar o pagamento na próxima colheita, no prazo de um ano. Assim, o cálculo de juros numa base anual era mais razoável; tão quanto o estabelecimento de juros compostos para o financiamento das antigas viagens comerciais, que não poderiam ser concluídas em um ano. Conforme a necessidade de cada época 
foi se criando novas formas de se trabalhar com a relação tempo-juros (juros semestral, bimestral, mensal, diário, etc).

Aprendendo a contar abstratamente e agrupar todas as espécies de elementos seguindo o princípio da base, o homem aprendeu assim a estimar, avaliar e medir diversas grandezas (pesos, comprimentos, áreas, volumes, capacidades etc.). Aprende igualmente a atingir e conceber números cada vez maiores, antes mesmo de ser capaz de dominar a ideia do infinito.

Pôde elaborar também várias técnicas operatórias e erguer os primeiros rudimentos de uma aritmética inicialmente prática, antes de tornar-se abstrata e conduzir à álgebra, onde hoje temos a Matemática Financeira amplamente desenvolvida.

O surgimento dos bancos está diretamente ligado ao cálculo de juros compostos e o uso da Matemática Comercial e Financeira de modo geral. Na época em que o comércio começava a chegar ao auge, uma das atividades do mercador foi também a do comércio de dinheiro: com o ouro e a prata. Nos diversos países eram cunhadas moedas de ouro e prata.

Durante a expansão do comércio, assim como durante as guerras de conquista, as moedas dos diferentes países eram trocadas, mas o pagamento só podia ser efetuado com dinheiro do país específico. Consequentemente, dentro das fronteiras de cada país, as moedas estrangeiras deviam ser cambiadas por dinheiro deste país. Por outro lado, os comerciantes e outras pessoas possuidoras de muito dinheiro, que viajavam ao exterior, precisavam de dinheiro de outros países, que compravam com moeda nacional. Com o passar do tempo, alguns comerciantes ficaram conhecendo bem as moedas estrangeiras e passaram a acumulá-las em grandes quantidades. Desta forma, dedicaram-se exclusivamente ao câmbio de dinheiro, ou seja, ao comércio de dinheiro.

Num espaço de tempo relativamente curto, acumularam-se fantásticas somas de dinheiro nas mãos dos cambistas. Com o tempo, foram se ocupando de uma nova atividade: guardar e emprestar dinheiro. Naquela época, e devido à deficiente organização das instituições responsáveis pela segurança social do indivíduo, não era recomendável que tivesse em sua casa muitas moedas de ouro e prata. Estas pessoas entregavam seu dinheiro à custódia do cambista rico, que o guardava e devolvia ao dono quando ele pedisse. Imaginemos um cambista qualquer que tenha acumulado, desta forma, em seus cofres, imensa quantidade de dinheiro.

Era natural que a seguinte ideia ocorresse: "Porque estas grandes somas de dinheiro haverão de permanecer em meu poder sem qualquer lucro para mim? É pouco provável que todos os proprietários, ao mesmo tempo e num mesmo dia, exijam a devolução imediata de todo seu dinheiro. Emprestarei parte deste dinheiro a quem pedir, sob a condição de que seja devolvido num prazo determinado. E como meu devedor empregará o dinheiro como quiser durante este é natural que eu obtenha alguma vantagem. Por isso, além do dinheiro emprestado, deverá entregar-me, no vencimento do 
prazo estipulado, uma soma adicional".

Vimos que neste pensamento do mercador, a ideia de lucro já aparece fortemente.

Assim tiveram início as operações creditícias. Aqueles que, por alguma razão, se encontravam sem dinheiro: os comerciantes, senhores feudais e não raras vezes o próprio rei ou o erário nacional, recorriam ao cambista que lhes emprestava grandes somas de dinheiro a juros "razoáveis".

O juro era pago pelo usufruto do dinheiro recebido ou, mais propriamente, era a "compensação pelo temor" de quem dava dinheiro emprestado e assim se expunha a um grande risco. Entretanto estes juros alcançaram, em alguns casos, quantias incríveis: na antiga Roma os usuários exigiam de 50 a 100 por cento e na Idade Média, de 100 a 200 por cento, às vezes mais, em relação direta com a necessidade do solicitante ou do montante da soma.

Estes juros foram chamados - com toda justiça - de usurário, o dinheiro recebido emprestado, de capital usurário e o credor, de usureiro. O cambista exercia sua profissão sentado num banco de madeira em algum lugar do mercado. Daí a origem da palavra "banqueiro"e "banco". Os primeiros bancos de verdade da História foram criados pelos sacerdotes.

No mundo antigo, entre os egípcios, babilônios e mais tarde entre os gregos e romanos, estava amplamente difundido o costume segundo o qual os cidadãos mais abastados deviam confiar a custódia de seu ouro aos sacerdotes.

A Igreja cristã não só deu continuidade à tradição das operações creditícias dos antigos sacerdotes, que considerava pagãos, mas desenvolveu-as em grande escala. A Igreja Católica criou o "Banco do Espírito Santo", com um fabuloso capital inicial. Seu verdadeiro propósito era facilitar o pagamento de dízimos e indulgências, assim como para a realização de transações relacionadas com os empréstimos, em outras palavras, com a usura.

Ao mesmo tempo lançou uma espécie de maldição e condenou às masmorras da inquisição os cidadãos que emprestavam dinheiro a juros, mesmo que este juro fosse menor do que aquele que ela exigia por seu dinheiro. A Igreja proibia a seus fiéis que cobrassem juros por seu dinheiro, invocando como autoridade a Sagrada Escritura, onde se lê: "Amai pois vossos inimigos e fazei o bem, e emprestei, nada esperando disso" (São Lucas, 6,35). Na realidade, esta proibição era motivada por um interesse econômico muito "mundano": a Igreja ambicionava assegurar para si o monopólio absoluto na cobrança de juros.

Apesar das maldições e ameaças com o fogo eterno, a Igreja não pôde conter a avidez por ganhos e lucros das pessoas, tanto mais que o próprio desenvolvimento do comércio exigia a criação de uma ampla rede bancária.

O primeiro banco privado foi fundado pelo duque Vitali, em 1157, em Veneza. Após este, nos séculos XIII, XIV e XV toda uma rede bancária foi criada. A Igreja não teve 
outra alternativa senão aceitar a realidade dos fatos. Assim os bancos foram um dos grandes propulsores práticos para o avanço da Matemática Comercial e Financeira e da Economia durante os séculos X até XV. Pois sem essa motivação para o aprimoramento dos cálculos, talvez, essa área de Matemática não estivesse tão avançada nos dias atuais.

\subsection{Matemática Financeira e Inflação}

Segundo Assaf (2012), em ambientes inflacionários é indispensável, para o uso correto das técnicas da matemática financeira, o componente devido à inflação. De maneira simplista, o processo inflacionário de uma economia pode ser entendido pela elevação generalizada de preços dos vários bens e serviços, com consequente perda do poder aquisitivo da moeda. Por outro lado, diante de uma baixa predominante dos preços, tem-se o fenômeno definido como deflação.

Tradicionalmente, o desenvolvimento da economia brasileira tem-se caracterizado pela presença marcante da inflação.

Os governos geralmente colocam como meta o combate à inflação, pois ela acarreta grandes distorções numa economia de mercado, tais como: perda do poder aquisitivo dos salários que não sofrerem reajustes no seu vencimento, perda do poder aquisitivo daqueles que recebem rendas fixas tais como aluguel, dificuldades do financiamento do setor público (o governo encontra dificuldade em vender seus títulos), etc.

Segundo Iezzi (2004), usualmente, a inflação é medida segundo a composição de uma cesta básica de produtos com quantidades físicas bem determinadas. Em seguida, mês a mês, os preços desses produtos são coletados e então, com base nos preços médios de cada produto, obtém-se o valor da cesta básica. A taxa de inflação mensal é a variação do valor da cesta básica calculada entre um mês e o mês anterior.

Ilustrativamente, na tabela 2.1, a seguir são relacionados os valores do IGP (Índice Geral de Preços - conceito calculado pela FGV) referente aos meses de maio a dezembro de um determinado ano.

\begin{tabular}{|c|c|c|c|c|c|c|c|c|}
\hline Mês & Mai & Jun & Jul & Ago & Set & Out & Nov & Dez \\
\hline IGP & 649,79 & 703,38 & 800,31 & 903,79 & 1009,67 & 1152,63 & 1353,79 & 1576,56 \\
\hline
\end{tabular}

Tabela 2.1: Índice geral de preços (FGV)

Pela evolução desses índices de preços pode ser constatado como os preços gerais da economia variaram no período. Para tanto, relaciona-se o índice do fim do período que se deseja estudar com o início do período. Por exemplo, a taxa de inflação do $2^{\circ}$ semestre medida pelo IGP está refletida na evolução apresentada entre o índice de junho (início do semestre) e o de dezembro (fim do semestre): 
Inflação do $2^{\circ}$ semestre $=\frac{I G P_{D e z}}{I G P_{J u n}}-1=\frac{1576,56}{703,38}-1=1,2414=124,14 \%$

Assim, os preços aumentaram 2,2414 (1 + 1,2414) vezes, indicando uma evolução de $124,14 \%$. Da mesma forma, a inflação do $4^{\circ}$ trimestre segue o mesmo raciocínio:

Logo a inflação do $4^{\circ}$ trimestre é $\frac{I G P_{D e z}}{I G P_{S e t}}-1=\frac{1576,56}{1009,67}-1=0,5615=56,15 \%$

A inflação verificada no mês de outubro atingiu 14,16\%, isto é:

Inflação de outubro $=\frac{I G P_{\text {Out }}}{I G P_{\text {Set }}}-1=\frac{1152,63}{1009,67}-1=0,1416=14,16 \%$, e assim por diante.

Dessa maneira, segundo Assaf (2012), a taxa de inflação pode ser medida pela seguinte expressão:

$$
I=\frac{P_{n}}{P_{n-t}}-1, \text { sendo: }
$$

I é a taxa de inflação obtida; P é o índice de preços utilizado para o cálculo da taxa de inflação; n,n-t são as datas de determinação da taxa e o período anterior considerado.

\section{Observações:}

1 - O exemplo dado foi elaborado considerando-se uma cesta básica de produtos definidas pela Fundação Getúlio Vargas (FGV) conhecida como IGP, mas existem outros índices oficiais de inflação, cada qual caracterizado pelos produtos da cesta básica, pela metodologia de cálculo ou pelo período e local de coleta de preços. Entre eles destacamos os Índices de preços ao consumidos (IPCs), cujas cestas básicas contêm produtos de consumo final, e são calculadas por diversas instituições nas grandes cidades, o Índice de Preços no Atacado (IPA), calculado pela FGV, com preços negociados no atacado e com dados coletados em todo país, o Índice Nacional do Custo da Construção (INCC), que envolve preços de produtos e serviços da construção civil. O IGP utiliza uma média ponderada do IPA, do IPC do Rio de Janeiro e São Paulo e do INCC, que representam $60 \%, 30 \%$ e $10 \%$, respectivamente, do IGP.

2 - A definição da taxa de inflação, de acordo com o que vimos, é baseada no método de Laspeyres (Étienne Laspeyres, 1834-1913, economista e estatístico alemão) com quantidade fixas na época base, sendo o mais utilizado na prática. No entanto, existem outras metodologias. 
Exemplo 2.2.1 - Na tabela 2.2 são apresentados alguns valores divulgados do IGP-di e do INPC (Índice Nacional de Preços ao Consumidor).

\begin{tabular}{|c|c|c|c|c|}
\hline & Dez/ano X & Jun/ano X+1 & Nov/ano X+1 & Dez/ano X+1 \\
\hline IGP-di & 100,00 & 708,38 & 1353,79 & 1576,56 \\
\hline INPC & 5,9341 & 43,4599 & 83,9349 & 100,00 \\
\hline
\end{tabular}

Tabela 2.2: IGP-di e INPC de um período passado

Com base nesses resultados, pede-se

a) Calcular a taxa de inflação, para cada um dos índices, para cada um dos períodos:

- Ano.

- $1^{\mathrm{o}}$ semestre.

- Dezembro/ano X+1.

b) Um bem que custava $\mathrm{R} \$ 5000,00$ no início do ano, quanto deve valer ao final deste ano se for corrigido pela variação dos índices?

c) Admitindo que o proprietário tenha vendido este imóvel ao final do ano por $\mathrm{R} \$$ 90000,00 , qual foi o lucro aferido?

Utilizando os conceitos trabalhados, temos:

a) A tabela 2.3 apresenta os cálculos para a taxa de inflação de acordo com os dois índices:

\begin{tabular}{|l|c|c|}
\hline & IGP & INPC \\
\hline a) Ano & $=\frac{1576,56}{100}-1=1476,56 \%$ & $=\frac{100}{5,9341}-1=1585,18 \%$ \\
\hline b) $1^{\circ}$ semestre & $=\frac{708,38}{100}-1=608,38 \%$ & $=\frac{43,4599}{5,9341}-1=632,38 \%$ \\
\hline c) Dezembro & $=\frac{1576,56}{1353,79}-1=16,46 \%$ & $=\frac{100}{83,9349}-1=19,14 \%$ \\
\hline
\end{tabular}

Tabela 2.3: Cálculos da taxa de inflação segundo os índices IGP e INPC

b) O valor corrigido do bem será obtido pelo produto entre o custo e o valor obtido na tabela 2.3 para a inflação no período:

$$
\begin{aligned}
& \text { Pelo IGP: }=5000 \cdot \frac{1576,56}{100}=78828,00 \\
& \text { Pelo INPC }=5000 \cdot \frac{100}{5,9341}=84258,80
\end{aligned}
$$


Portanto, o valor do imóvel passaria a $\mathrm{R} \$ 78828,00$ se corrigido pelo IGP e $\mathrm{R} \$ 84258,80$ se corrigido pelo INPC.

c) O lucro pode ser avaliado sob duas formas: o nominal, medido pela simples diferença entre o valor de venda e o de compra, e o real (nosso foco), apurado adicionalmente à inflação.

No caso em questão, o proprietário vendeu o imóvel apurando lucro real, isto é, o preço de venda excedeu o valor de compra corrigido. Assim, pelo IGP, apura-se um lucro real de: $\mathrm{R} \$ 90000,00$ - $\mathrm{R} \$ 78828,00=\mathrm{R} \$ 11172,00$ e pelo INPC, o lucro real foi menor: $\mathrm{R} \$ 90000,00-\mathrm{R} \$ 84258,80=\mathrm{R} \$ 5741,20$.

Exemplo 2.2.2 - Um investidor aplicou $\mathrm{R} \$ 100000,00$ e obteve, ao final de um ano, rendimentos de juros de $\mathrm{R} \$ 12000,00$. Sabe-se que, no período de aplicação, a inflação da economia brasileira atingiu $5,6 \%$. Nestas condições, qual foi seu ganho real?

A solução do problema consiste em verificar os efeitos da inflação sobre o valor do investimento para posterior comparação com os rendimentos obtidos, obtendo assim o ganho real:

O investidor apurou os seguintes resultados:

Rendimento nominal: $\mathrm{R} \$ 12000,00$

Inflação no período: $5,6 \% \cdot R \$ 100000,00=R \$ 5600,00$

Ganho do investidor acima da inflação (ganho real): $\mathrm{R} \$ 12000,00-\mathrm{R} \$ 5600,00=\mathrm{R} \$$ 6400,00

Valor da aplicação corrigido para o final do ano:R $\$ 112000,00$

Capital corrigido: $\mathrm{R} \$ 105600,00$

O ganho real é obtido após depurar-se os efeitos da inflação do investimento. É apurado pela razão entre o rendimento real $(\mathrm{R} \$ 6400,00)$ e o capital corrigido pela inflação ( $\mathrm{R} \$$ $105600,00)$.

$$
\text { Retorno real }=\frac{6400}{105600}=6,06 \% \text { ou }=\frac{112000}{105600}-1=6,06 \%
$$

\subsubsection{Comportamento acumulativo da taxa de inflação}

Segundo Assaf (2012), o comportamento da inflação se processa de maneira acumulativa, ocorrendo aumento de preço sobre um valor que já incorpora acréscimos apurados de períodos anteriores. Da mesma forma que o regime de juros compostos, a formação da taxa de inflação assemelha-se a uma progressão geométrica, verificando-se juros sobre juros. Por exemplo, sendo de 2,8\%, 1,4\% e 3,0\%, respectivamente, as taxas de inflação dos três primeiros meses de um ano, um ativo de $\mathrm{R} \$ 12000,00$ no início do ano, se corrigido plenamente pela inflação da economia, apresentaria os seguintes 
valores ao final dos meses:

$1^{\circ}$ mês: $R \$ 12000,00 \cdot 1,028=R \$ 12336,00$

$2^{\circ}$ mês: $R \$ 12336,00 \cdot 1,014=R \$ 12508,70$

$3^{\circ}$ mês: $R \$ 12508,70 \cdot 1,03=R \$ 12883,97$

O incremento do valor do ativo no trimestre é de $7,37 \%$, o que equivale ao produto das taxas mensais de inflação, isto é:

Inflação do trimestre $(I)=[(1,028) \cdot(1,014) \cdot(1,03)]-1=7,37 \%$

Assim, a taxa equivalente mensal de inflação do período, identicamente ao regime de juros compostos, é apurada pela média geométrica:

Taxa equivalente mensal $I_{q}=\sqrt[3]{1,0737}-1=2,4 \%$ ao mês.

Dessa forma, são válidos para a inflação os mesmos conceitos e expressões já trabalhados no assunto juros compostos.

Exemplo 2.2.3 - A taxa mensal de inflação de um quadrimestre atinge, respectivamente, $2,8 \%, 3,4 \%, 5,7 \%$ e $8,8 \%$. Determinar a taxa de inflação acumulada do período e a taxa equivalente mensal.

Conforme mencionado acima, para o cálculo da inflação no quadrimestre temos:

$$
I=[(1,028) \cdot(1,034) \cdot(1,057) \cdot(1,088)]-1=22,2 \% \text { a.q. }
$$

Para o cálculo da taxa equivalente mensal, temos:

$$
I_{q}=\sqrt[4]{1,222}-1=15 \% \text { a.m. }
$$

Exemplo 2.2.4 - A taxa de inflação da economia num determinado ano foi de 6,78\%. Calcular a taxa equivalente semestral e mensal da inflação do período.

Para o cálculo das taxas equivalentes, temos:

$$
\begin{aligned}
& \text { Semestral: } I_{q}=\sqrt{1+0,0678}-1=3,33 \% \text { a.s. } \\
& \text { Mensal: } I_{q}=\sqrt[12]{1+0,0678}-1=0,548 \% \text { a.m. }
\end{aligned}
$$

Exemplo 2.2.5 - Sendo projetada 0,91\% a. m. a taxa de inflação para os próximos 5 meses, determinar a inflação acumulada no período.

No caso, a inflação acumulada para os 5 meses será: $I=(1,0091)^{5}-1=4,63 \%$ para 5 meses.

Exemplo 2.2.6 - Determinado trimestre apresenta as seguintes taxas mensais de variações nos preços gerais da economia: 7,2\%,2,9\% e - 1,2\% (deflação). Determinar 
a taxa de inflação acumulada no trimestre.

O destaque do exemplo é a presença da deflação. Para isso, temos:

$$
I(\text { trim. })=[(1,072) \cdot(1,029) \cdot(0,988)]-1=8,99 \% \text { a.t. }
$$

\subsubsection{Taxa de desvalorização da moeda}

Segundo Assaf (2012), enquanto a inflação representa uma elevação nos níveis de preço, a taxa de desvalorização da moeda (TDM) mede a queda no poder de compra da moeda causada por estes aumentos de preços. Por exemplo, se em determinado período os preços em geral dobraram (inflação de 100\%), conclui-se que a capacidade de compra das pessoas se reduziu em $50 \%$, ou seja, somente podem adquirir a metade do que costumavam consumir no passado. Diz-se, em outras palavras, que a capacidade aquisitiva da moeda diminuiu em $50 \%$.

A taxa de desvalorização da moeda (TDM), para diferentes taxas de inflação I, pode ser obtida a partir da seguinte fórmula:

$$
T D M=\frac{I}{1+I},
$$

sendo I a taxa de inflação no período.

Por exemplo, se em determinado período a taxa de inflação alcançar 8\%, a queda na capacidade de compra registra a marca de $7,4 \%$, isto é:

$$
T D M=\frac{0,08}{1+0,08}=7,4 \%,
$$

A inflação de $8 \%$ indica uma redução do poder de compra da moeda igual a 7,4\%, isto é, com este percentual de evolução dos preços as pessoas adquirem 7,4\% a menos de bens e serviços que consumiriam anteriormente.

\subsubsection{Taxa Referencial - TR}

Segundo Assaf (2012), a taxa referencial (TR) é apurada a partir das taxas prefixadas de juros praticadas pelos bancos na colocação de títulos de sua emissão. A TR é utilizada como um indexador em diversos contratos de financiamentos (inclusive nos pagamentos de seguros), e também em aplicações financeiras, como a caderneta de poupança.

A TR é calculada e divulgada pelo Banco Central do Brasil, e obedece à seguinte metodologia de apuração:

- Diariamente, os principais bancos captadores de recursos informam ao Banco Central suas taxas de juros pagas aos aplicadores com certificados e recibos de depósitos bancários (prefixados), de emissão de 30 a 35 dias; 
- O Banco Central calcula então a média ponderada de juros pagos pelo mercado bancário, sendo esta média conhecida como Taxa Básica Financeira (TBF). A TBF representa, dessa forma, o custo médio de captação dos bancos na colocação de seus títulos de renda fixa no mercado;

- Sobre a TBF, o Banco Central aplica um redutor, obtendo assim a Taxa Referencial (TR).

O cálculo do redutor segue, em essência, os critérios de política econômica de competência do Banco Central. Ao elevar o valor do redutor, a autoridade monetária imprime menor custo ao tomador de empréstimo corrigido em TR e, ao mesmo tempo, reduz os rendimentos dos aplicadores em caderneta de poupança. De maneira inversa, ao diminuir o redutor, promove uma elevação no empréstimo indexado à TR, incentivando, ainda, as aplicações em caderneta de poupança pelo aumento dos seus rendimentos.

\subsubsection{Caderneta de Poupança}

Como já citado na seção 1.2.5.3, a caderneta de poupança é considerada a modalidade de aplicação financeira mais popular do mercado brasileiro. Seus principais atrativos encontram-se na liquidez imediata (o aplicador pode sacar o seu saldo a qualquer momento), na garantia de pagamento dada pelo governo, e na isenção de impostos.

A remuneração da caderneta de poupança está atualmente fixada pela TR mais 0,5\% a. m. de juros, sendo creditada mensalmente para os depositantes pessoas físicas. O cálculo dos rendimentos tem por base sempre o menor saldo mantido pelo aplicador no período.

Exemplo 2.2.7 - admita uma aplicação de $\mathrm{R} \$ 7500,00$ em caderneta de poupança por dois meses. A TR definida para cada mês (na data de aniversário do depósito) é a seguinte:

Mês 1: 0,6839\% a.m.

Mês 2: 0,7044\% a.m.

Determinar o saldo disponível ao aplicador ao final de cada período e a rentabilidade efetiva da aplicação. (Considere a taxa Selic de $14,25 \%$ a.a.).

Para o cálculo do saldo disponível ao aplicador ao final do período temos:

Mês 1: $F V_{1}=R \$ 7500,00 \cdot(1,006839) \cdot(1,005)=R \$ 7589,05$

Mês $2: F V_{2}=R \$ 7589,04 \cdot(1,007044) \cdot(1,005)=R \$ 7680,72$ 
Portanto, ao final do bimestre o aplicador terá $\mathrm{R} \$ 7680,72$.

A Rentabilidade efetiva da aplicação no bimestre será dada por: $i_{2}=\left[(1,006839) \cdot(1,007044) \cdot(1,005)^{2}\right]-1=2,41 \%$ a.b.

Para o cálculo da rentabilidade mensal, temos: $\left.i_{1}=(1,0241)^{\frac{1}{2}}\right)-1=1,198 \%$ a.m.

\subsection{Valor atual de um conjunto de capitais}

Segundo Bruni (2003), o valor atual ou presente é o valor que um compromisso tem em uma data que antecede ao seu vencimento. Para calcular o valor atual é necessário especificar o valor nominal, a data de cálculo e a taxa de juros.

Exemplo 2.3.1 - Suponhamos que uma pessoa tenha uma dívida de R\$15000,00 que vence daqui a um mês. Suponhamos ainda que ela consiga aplicar seu dinheiro a uma taxa de $2 \%$ a.m. Quanto essa pessoa deverá aplicar hoje àquela taxa para ter dinheiro suficiente para pagar a dívida?

Aplicando o conceito de juros compostos, temos:

$$
M=C \cdot(1+i)^{t} \Rightarrow 15000=C \cdot(1,02)^{1} \Rightarrow C=\frac{15000}{1,02}=14705,88
$$

O valor encontrado acima é chamado de valor atual ou valor presente de $\mathrm{R} \$ 15000,00$ a uma taxa de $2 \%$ a.m.

No exemplo citado, caso a pessoa tivesse uma dívida de $\mathrm{R} \$ 15000,00$ para daqui a 1 mês e outra de $\mathrm{R} \$ 16000,00$ para daqui a 2 meses, o valor que ela precisaria para pagar ambos os compromissos poderia ser obtido da seguinte forma:

Para pagar a dívida de $\mathrm{R} \$ 15000,00$, hoje a pessoa precisaria de:

$C=\frac{15000}{1,02}=14705,88$

Para pagar a dívida de $\mathrm{R} \$ 16000,00$, hoje a pessoa precisaria de:

$C=\frac{16000}{(1,02)^{2}}=15378,70$

Portanto, para saldar as duas dívidas, hoje ela precisaria de:

$C=\frac{15000}{1,02}+\frac{16000}{(1,02)^{2}}=30084,58$

Esse valor é chamado de valor atual da dívida à taxa de $2 \%$. 
Segundo Iezzi (2004), de modo geral, dado um conjunto de valores monetários $Y_{1}$ na data $1, Y_{2}$ na data $2, Y_{3}$ na data 3 , e assim por diante até o valor $Y_{n}$ na data n, chamaremos de valor atual desse conjunto, a uma taxa $\mathrm{i}$, ao valor indicado por $\mathrm{V}$ :

$$
V=\frac{Y_{1}}{(1+i)^{1}}+\frac{Y_{2}}{(1+i)^{2}}+\frac{Y_{3}}{(1+i)^{3}}+\ldots+\frac{Y_{n}}{(1+i)^{n}}
$$

Exemplo 2.3.2 - Uma pessoa tem dívidas de $\mathrm{R} \$ 2000,00, \mathrm{R} \$ 3500,00$ e $\mathrm{R} \$ 5000,00$ que vencem dentro de 2, 5 e 6 meses, respectivamente. Quanto deverá aplicar hoje, a taxa de $1 \%$ a.m., para poder pagar os compromissos?

Para o cálculo do valor atual, temos:

$$
V=\frac{2000}{(1,01)^{2}}+\frac{3500}{(1,01)^{5}}+\frac{5000}{(1,01)^{6}}=1960,59+3330,13+4710,23=10000,95
$$

Portanto, o valor a ser aplicado hoje é de $\mathrm{R} \$ 10000,95$.

Exemplo 2.3.3 - Um conjunto de sofás é vendido à prazo em 5 prestações mensais de $\mathrm{R} \$ 400,00$ cada uma, sendo a primeira um mês após a compra. Se o pagamento for à vista, o preço cobrado é $\mathrm{R} \$ 1750,00$. Qual a melhor alternativa de pagamento de um comprador que consegue aplicar seu dinheiro à taxa de $2 \%$ a.m.

Para podermos comparar as duas alternativas, temos de obter o valor atual das duas alternativas e escolher a de menor valor. Evidentemente que o valor atual do pagamento à vista é $\mathrm{R} \$ 1750,00$.

O valor atual do pagamento à prazo, considerando uma taxa de $2 \%$ é:

$V=\frac{400}{(1,02)^{1}}+\frac{400}{(1,02)^{2}}+\frac{400}{(1,02)^{3}}+\frac{400}{(1,02)^{4}}+\frac{400}{(1,02)^{5}}$.

Assim:

$V=392,16+384,47+376,93+369,54+362,29=1885,39$

Como o valor atual do pagamento à vista é menor do que o valor atual do pagamento a prazo, a melhor alternativa é o pagamento à vista.

\subsection{Sistemas de amortização de empréstimos e fi- nanciamentos}

Segundo Assaf (2012), os sistemas de amortização são desenvolvidos basicamente para operações de empréstimos e financiamentos, envolvendo desembolsos periódicos do principal e encargos financeiros.

Existem diversas maneiras de se amortizar uma dívida, devendo as condições de cada operação estarem estabelecidas em contrato firmado entre credor e o devedor.

Uma característica fundamental dos sistemas de amortização é a utilização exclusiva do critério de juros compostos, incidindo juros exclusivamente sobre o saldo devedor (montante) apurado em período imediatamente anterior. 
São consideradas também modalidades de pagamentos com e sem carência. No período de carência, não há pagamento do principal, sendo pagos somente os juros. Eventualmente, os juros podem ser capitalizados durante o período de carência.

Por serem os mais usuais para a realidade brasileira, vamos tratar os seguintes sistemas de amortização:

a) Sistema de amortização constante (SAC);

b) Sistema de prestação constante (SPC) também conhecido por sistema de amortização francês (SAF) ou ainda Tabela PRICE.

Para aplicarmos os sistemas de amortização acima é importante definirmos os conceitos seguintes:

- Encargos (Despesas) Financeiros - Representam os juros da operação, caracterizandose como custo para o devedor e retorno para o credor.

Os encargos podem ser prefixados ou pós-fixados. O que distingue essas duas modalidades é a correção (indexação) da dívida em função de uma expectativa (prefixação) ou verificação posterior (pós-fixação) do comportamento de determinado indexador.

- Amortização - Refere-se exclusivamente ao pagamento do principal (capital emprestado), o que é efetuado, geralmente, mediante parcelas periódicas (mensais, trimestrais, etc.).

- Saldo devedor - O valor do principal da dívida, em determinado momento, após a dedução do valor já pago ao credor a título de amortização.

- Prestação - É composto do valor de amortização mais os encargos financeiros devidos em determinado período de tempo.

- Carência - É um prazo dado ao devedor para o pagamento da primeira prestação. É importante ressaltar que a carência significa a postergação só do principal, os juros podem, dependendo das condições contratuais, serem pagos ou não durante a carência.

Exemplo 2.4.1 - Visando ilustrar os sistemas de amortização mencionados admitiremos um empréstimo com as seguintes condições básicas:

- Valor do empréstimo: $\mathrm{R} \$ 100000,00$;

- Prazo da operação: 5 anos;

- Taxa de juros: $30 \%$ ao ano (efetiva). 


\subsubsection{Sistema de amortização constante (SAC)}

Segundo Assaf (2012), o SAC tem como característica básica serem as amortizações do principal sempre iguais (ou constantes) em todo prazo da operação. Um exemplo de aplicação do SAC é nos financiamentos habitacionais.

O valor da amortização é facilmente obtido mediante a divisão do capital emprestado pelo número de prestações.

$$
A=\frac{P V}{n}
$$

onde A é a amortização, $\mathrm{PV}=$ principal (valor do financiamento) e $\mathrm{n}=$ número de prestações.

Os juros, por incidirem sobre o saldo devedor, cujo montante decresce após o pagamento de cada amortização, assumem valores decrescentes nos períodos.

Pela redução constante do saldo devedor, os juros diminuem linearmente ao longo do tempo, comportando-se como uma Progressão Aritmética (PA) decrescente. O valor periódico da redução (razão da PA) é dado pelo produto da amortização pela taxa. Logo, pela fórmula do termo geral de uma PA:

$$
J_{t}=a_{1}+(n-1) \cdot r
$$

sendo: $a_{1}=P V \cdot i, \mathrm{n}=\mathrm{t}$ e $r=\frac{P V}{n} \cdot i$.

Logo:

$$
J_{t}=P V \cdot i+(t-1) \cdot \frac{P V}{n} \cdot i=\left(\frac{P V \cdot n-(t-1)}{n}\right) \cdot i=\frac{P V}{n} \cdot(n-t+1) \cdot i
$$

sendo: $\mathrm{PV}=$ principal, i é a taxa de juros, $\mathrm{t}$ é o tempo e $\mathrm{n}=\mathrm{n}^{\mathrm{o}}$ de prestações.

Em consequência do comportamento da amortização e dos juros, as prestações periódicas e sucessivas (PMT) do SAC são decrescentes em progressão aritmética e são dadas pela soma da amortização com os juros no tempo t, conforme segue:

$$
P M T=A+J_{t}=\frac{P V}{n}+\frac{P V}{n} \cdot(n-t+1) \cdot i=\frac{P V}{n} \cdot(1+(n-t+1) \cdot i)
$$

onde PV = principal, i é a taxa de juros, t é o tempo e $\mathrm{n}=$ número de prestações

Admita que o empréstimo citado no exemplo 2.4.1 seja pago em 10 prestações semestrais, sem carência. Podemos então elaborar a tabela 2.4 seguinte:

Conforme foi comentado, o SAC determina que a restituição do principal (capital emprestado) seja efetuada em parcelas iguais. Assim:

Amortização $=$ Valor do empréstimo $/ \mathrm{n}^{\circ}$ de prestações $=100000 / 10$.

Logo:

Amortização= R $\$ 10000,00 /$ semestre.

Os pagamentos desses valores determinam, como é natural, decréscimos iguais e constantes no saldo devedor em cada um dos períodos, ocasionando ainda reduções nos valores semestrais dos juros e das prestações. 


\begin{tabular}{|c|c|c|c|c|}
\hline $\begin{array}{c}\text { Períodos } \\
\text { (semestres) }\end{array}$ & $\begin{array}{c}\text { Saldo devedor } \\
(\mathrm{R} \$)\end{array}$ & $\begin{array}{c}\text { Amortização } \\
(\mathrm{R} \$)\end{array}$ & $\begin{array}{c}\text { Juros } \\
(\mathrm{R} \$)\end{array}$ & $\begin{array}{c}\text { Prestação } \\
(\mathrm{R} \$)\end{array}$ \\
\hline 0 & $\mathrm{R} \$ 100.000,00$ & & & \\
\hline 1 & $\mathrm{R} \$ 90.000,00$ & $\mathrm{R} \$ 10.000,00$ & $\mathrm{R} \$ 14.017,50$ & $\mathrm{R} \$ 24.017,50$ \\
\hline 2 & $\mathrm{R} \$ 80.000,00$ & $\mathrm{R} \$ 10.000,00$ & $\mathrm{R} \$ 12.615,75$ & $\mathrm{R} \$ 22.615,75$ \\
\hline 3 & $\mathrm{R} \$ 70.000,00$ & $\mathrm{R} \$ 10.000,00$ & $\mathrm{R} \$ 11.214,00$ & $\mathrm{R} \$ 21.214,00$ \\
\hline 4 & $\mathrm{R} \$ 60.000,00$ & $\mathrm{R} \$ 10.000,00$ & $\mathrm{R} \$ 9.812,25$ & $\mathrm{R} \$ 19.812,25$ \\
\hline 5 & $\mathrm{R} \$ 50.000,00$ & $\mathrm{R} \$ 10.000,00$ & $\mathrm{R} \$ 8.410,50$ & $\mathrm{R} \$ 18.410,50$ \\
\hline 6 & $\mathrm{R} \$ 40.000,00$ & $\mathrm{R} \$ 10.000,00$ & $\mathrm{R} \$ 7.008,75$ & $\mathrm{R} \$ 17.008,75$ \\
\hline 7 & $\mathrm{R} \$ 30.000,00$ & $\mathrm{R} \$ 10.000,00$ & $\mathrm{R} \$ 5.607,00$ & $\mathrm{R} \$ 15.607,00$ \\
\hline 8 & $\mathrm{R} \$ 20.000,00$ & $\mathrm{R} \$ 10.000,00$ & $\mathrm{R} \$ 4.205,25$ & $\mathrm{R} \$ 14.205,25$ \\
\hline 9 & $\mathrm{R} \$ 10.000,00$ & $\mathrm{R} \$ 10.000,00$ & $\mathrm{R} \$ 2.803,50$ & $\mathrm{R} \$ 12.803,50$ \\
\hline 10 & $\mathrm{R} \$ 0,00$ & $\mathrm{R} \$ 10.000,00$ & $\mathrm{R} \$ 1.401,75$ & $\mathrm{R} \$ 11.401,75$ \\
\hline
\end{tabular}

Tabela 2.4: Exemplo 2.4.1 pago pelo SAC em 10 prestações semestrais, sem carência

Para o cálculo dos juros trabalhamos com o conceito já estudado de juros compostos e de taxas equivalentes.

Taxa equivalente semestral de $30 \%$ a.a. $=(1+0,3)^{\frac{1}{2}}-1=\sqrt{1,3}-1=14,0175 \%$ a.s.

Os juros, por incidirem sobre o saldo devedor imediatamente anterior, apresentam valores em PA decrescente, conforme apurado na penúltima coluna da tabela acima. Somando-se, para cada período, o valor da amortização com os respectivos juros, temse o valor da prestação semestral do financiamento. Assim, para o primeiro semestre a prestação atinge: $\mathrm{R} \$ 10000,00+\mathrm{R} \$ 14017,50=\mathrm{R} \$ 24017,50$, e assim sucessivamente.

\section{SAC com carência}

Conforme já citado, carência é um prazo dado ao devedor para o pagamento da primeira prestação. É importante ressaltar que a carência significa a postergação só do principal, os juros podem, dependendo das condições contratuais, serem pagos ou não durante a carência. Ao se supor uma carência de 2 anos (contada a partir do final do primeiro semestre), por exemplo, três cenários podem ocorrer:

a) Os juros são pagos durante a carência;

b) Os juros são capitalizados e pagos totalmente quando do vencimento da primeira amortização;

c) Os juros são capitalizados e acrescidos ao saldo devedor gerando um fluxo de amortizações de maior valor.

Os quadros apresentados a seguir ilustram as situações, respectivamente: 
a) A tabela 2.5 apresenta o SAC com carência (2 anos) e pagamento periódico dos juros:

\begin{tabular}{|c|c|c|c|c|}
\hline $\begin{array}{c}\text { Períodos } \\
\text { (semestres })\end{array}$ & $\begin{array}{c}\text { Saldo devedor } \\
(\mathrm{R} \$)\end{array}$ & $\begin{array}{c}\text { Amortização } \\
(\mathrm{R} \$)\end{array}$ & $\begin{array}{c}\text { Juros } \\
(\mathrm{R} \$)\end{array}$ & $\begin{array}{c}\text { Prestação } \\
(\mathrm{R} \$)\end{array}$ \\
\hline 0 & $\mathrm{R} \$ 100.000,00$ & & & \\
\hline 1 a 4 & $\mathrm{R} \$ 100.000,00$ & & $\mathrm{R} \$ 14.017,50$ & $\mathrm{R} \$ 14.017,50$ \\
\hline 5 & $\mathrm{R} \$ 90.000,00$ & $\mathrm{R} \$ 10.000,00$ & $\mathrm{R} \$ 14.017,50$ & $\mathrm{R} \$ 24.017,50$ \\
\hline 6 & $\mathrm{R} \$ 80.000,00$ & $\mathrm{R} \$ 10.000,00$ & $\mathrm{R} \$ 12.615,75$ & $\mathrm{R} \$ 22.615,75$ \\
\hline 7 & $\mathrm{R} \$ 70.000,00$ & $\mathrm{R} \$ 10.000,00$ & $\mathrm{R} \$ 11.214,00$ & $\mathrm{R} \$ 21.214,00$ \\
\hline 8 & $\mathrm{R} \$ 60.000,00$ & $\mathrm{R} \$ 10.000,00$ & $\mathrm{R} \$ 9.812,25$ & $\mathrm{R} \$ 19.812,25$ \\
\hline 9 & $\mathrm{R} \$ 50.000,00$ & $\mathrm{R} \$ 10.000,00$ & $\mathrm{R} \$ 8.410,50$ & $\mathrm{R} \$ 18.410,50$ \\
\hline 10 & $\mathrm{R} \$ 40.000,00$ & $\mathrm{R} \$ 10.000,00$ & $\mathrm{R} \$ 7.008,75$ & $\mathrm{R} \$ 17.008,75$ \\
\hline 11 & $\mathrm{R} \$ 30.000,00$ & $\mathrm{R} \$ 10.000,00$ & $\mathrm{R} \$ 5.607,00$ & $\mathrm{R} \$ 15.607,00$ \\
\hline 12 & $\mathrm{R} \$ 20.000,00$ & $\mathrm{R} \$ 10.000,00$ & $\mathrm{R} \$ 4.205,25$ & $\mathrm{R} \$ 14.205,25$ \\
\hline 13 & $\mathrm{R} \$ 10.000,00$ & $\mathrm{R} \$ 10.000,00$ & $\mathrm{R} \$ 2.803,50$ & $\mathrm{R} \$ 12.803,50$ \\
\hline 14 & $\mathrm{R} \$ 0,00$ & $\mathrm{R} \$ 10.000,00$ & $\mathrm{R} \$ 1.401,75$ & $\mathrm{R} \$ 11.401,75$ \\
\hline
\end{tabular}

Tabela 2.5: SAC com carência onde os juros são pagos durante a carência

b) A tabela 2.6 apresenta o SAC com carência (2 anos) e capitalização dos juros para pagamento na $1^{\mathrm{a}}$ parcela:

\begin{tabular}{|c|c|c|c|c|}
\hline $\begin{array}{c}\text { Períodos } \\
\text { (semestres) }\end{array}$ & $\begin{array}{c}\text { Saldo devedor } \\
(\mathrm{R} \$)\end{array}$ & $\begin{array}{c}\text { Amortização } \\
(\mathrm{R} \$)\end{array}$ & $\begin{array}{c}\text { Juros } \\
(\mathrm{R} \$)\end{array}$ & $\begin{array}{c}\text { Prestação } \\
(\mathrm{R} \$)\end{array}$ \\
\hline 0 a 4 & $\mathrm{R} \$ 100.000,00$ & & & \\
\hline 5 & $\mathrm{R} \$ 90.000,00$ & $\mathrm{R} \$ 10.000,00$ & $\mathrm{R} \$ 92.615,75$ & $\mathrm{R} \$ 102.689,29$ \\
\hline 6 & $\mathrm{R} \$ 80.000,00$ & $\mathrm{R} \$ 10.000,00$ & $\mathrm{R} \$ 12.615,75$ & $\mathrm{R} \$ 22.615,75$ \\
\hline 7 & $\mathrm{R} \$ 70.000,00$ & $\mathrm{R} \$ 10.000,00$ & $\mathrm{R} \$ 11.214,00$ & $\mathrm{R} \$ 21.214,00$ \\
\hline 8 & $\mathrm{R} \$ 60.000,00$ & $\mathrm{R} \$ 10.000,00$ & $\mathrm{R} \$ 9.812,25$ & $\mathrm{R} \$ 19.812,25$ \\
\hline 9 & $\mathrm{R} \$ 50.000,00$ & $\mathrm{R} \$ 10.000,00$ & $\mathrm{R} \$ 8.410,50$ & $\mathrm{R} \$ 18.410,50$ \\
\hline 10 & $\mathrm{R} \$ 40.000,00$ & $\mathrm{R} \$ 10.000,00$ & $\mathrm{R} \$ 7.008,75$ & $\mathrm{R} \$ 17.008,75$ \\
\hline 11 & $\mathrm{R} \$ 30.000,00$ & $\mathrm{R} \$ 10.000,00$ & $\mathrm{R} \$ 5.607,00$ & $\mathrm{R} \$ 15.607,00$ \\
\hline 12 & $\mathrm{R} \$ 20.000,00$ & $\mathrm{R} \$ 10.000,00$ & $\mathrm{R} \$ 4.205,25$ & $\mathrm{R} \$ 14.205,25$ \\
\hline 13 & $\mathrm{R} \$ 10.000,00$ & $\mathrm{R} \$ 10.000,00$ & $\mathrm{R} \$ 2.803,50$ & $\mathrm{R} \$ 12.803,50$ \\
\hline 14 & $\mathrm{R} \$ 0,00$ & $\mathrm{R} \$ 10.000,00$ & $\mathrm{R} \$ 1.401,75$ & $\mathrm{R} \$ 11.401,75$ \\
\hline
\end{tabular}

Tabela 2.6: SAC com carência onde os juros são capitalizados e pagos totalmente quando do vencimento da primeira amortização 
c) A tabela 2.7 apresenta o SAC com carência (2 anos) com juros capitalizados e acrescidos ao saldo devedor:

\begin{tabular}{|c|c|c|c|c|}
\hline $\begin{array}{c}\text { Períodos } \\
\text { (semestres) }\end{array}$ & $\begin{array}{c}\text { Saldo devedor } \\
(\mathrm{R} \$)\end{array}$ & $\begin{array}{c}\text { Amortização } \\
(\mathrm{R} \$)\end{array}$ & $\begin{array}{c}\text { Juros } \\
(\mathrm{R} \$)\end{array}$ & $\begin{array}{c}\text { Prestação } \\
(\mathrm{R} \$)\end{array}$ \\
\hline 0 & $\mathrm{R} \$ 100.000,00$ & & & \\
\hline 1 & $\mathrm{R} \$ 114.017,50$ & & & \\
\hline 2 & $\mathrm{R} \$ 129.999,90$ & & & \\
\hline 3 & $\mathrm{R} \$ 148.222,64$ & & & \\
\hline 4 & $\mathrm{R} \$ 169.000,00$ & & & \\
\hline 5 & $\mathrm{R} \$ 152.100,00$ & $\mathrm{R} \$ 16.900,00$ & $\mathrm{R} \$ 23.689,58$ & $\mathrm{R} \$ 40.589,58$ \\
\hline 6 & $\mathrm{R} \$ 135.200,00$ & $\mathrm{R} \$ 16.900,00$ & $\mathrm{R} \$ 21.320,62$ & $\mathrm{R} \$ 38.220,62$ \\
\hline 7 & $\mathrm{R} \$ 118.300,00$ & $\mathrm{R} \$ 16.900,00$ & $\mathrm{R} \$ 18.951,66$ & $\mathrm{R} \$ 35.854,66$ \\
\hline 8 & $\mathrm{R} \$ 101.400,00$ & $\mathrm{R} \$ 16.900,00$ & $\mathrm{R} \$ 16.582,70$ & $\mathrm{R} \$ 33.482,70$ \\
\hline 9 & $\mathrm{R} \$ 84.500,00$ & $\mathrm{R} \$ 16.900,00$ & $\mathrm{R} \$ 14.213,75$ & $\mathrm{R} \$ 31.113,75$ \\
\hline 10 & $\mathrm{R} \$ 67.600,00$ & $\mathrm{R} \$ 16.900,00$ & $\mathrm{R} \$ 11.844,79$ & $\mathrm{R} \$ 28.744,79$ \\
\hline 11 & $\mathrm{R} \$ 50.700,00$ & $\mathrm{R} \$ 16.900,00$ & $\mathrm{R} \$ 9.475,83$ & $\mathrm{R} \$ 26.375,83$ \\
\hline 12 & $\mathrm{R} \$ 33.800,00$ & $\mathrm{R} \$ 16.900,00$ & $\mathrm{R} \$ 7.106,87$ & $\mathrm{R} \$ 24.006,87$ \\
\hline 13 & $\mathrm{R} \$ 16.900,00$ & $\mathrm{R} \$ 16.900,00$ & $\mathrm{R} \$ 4.737,92$ & $\mathrm{R} \$ 21.637,92$ \\
\hline 14 & $\mathrm{R} \$ 0,00$ & $\mathrm{R} \$ 16.900,00$ & $\mathrm{R} \$ 2.368,96$ & $\mathrm{R} \$ 19.268,96$ \\
\hline
\end{tabular}

Tabela 2.7: SAC com carência onde os juros são capitalizados e acrescidos ao saldo devedor gerando um fluxo de amortizações de maior valor

Exemplo 2.4.2 - Uma dívida de $\mathrm{R} \$ 1000,00$ é paga, com juros de $15 \%$ a.m., em 5 meses, pelo SAC. Construa a tabela de amortização.

Apresentamos a tabela 2.8, solução do exemplo 2.4.2:

\begin{tabular}{|c|c|c|c|c|}
\hline $\begin{array}{c}\text { Períodos } \\
(\text { meses })\end{array}$ & $\begin{array}{c}\text { Saldo devedor } \\
(\mathrm{R} \$)\end{array}$ & $\begin{array}{c}\text { Amortização } \\
(\mathrm{R} \$)\end{array}$ & $\begin{array}{c}\text { Juros } \\
(\mathrm{R} \$)\end{array}$ & $\begin{array}{c}\text { Prestação } \\
(\mathrm{R} \$)\end{array}$ \\
\hline 0 & $\mathrm{R} \$ 1.000,00$ & & & \\
\hline 1 & $\mathrm{R} \$ 800,00$ & $\mathrm{R} \$ 200,00$ & $\mathrm{R} \$ 150,00$ & $\mathrm{R} \$ 350,00$ \\
\hline 2 & $\mathrm{R} \$ 600,00$ & $\mathrm{R} \$ 200,00$ & $\mathrm{R} \$ 120,00$ & $\mathrm{R} \$ 320,00$ \\
\hline 3 & $\mathrm{R} \$ 400,00$ & $\mathrm{R} \$ 200,00$ & $\mathrm{R} \$ 90,00$ & $\mathrm{R} \$ 290,00$ \\
\hline 4 & $\mathrm{R} \$ 200,00$ & $\mathrm{R} \$ 200,00$ & $\mathrm{R} \$ 60,00$ & $\mathrm{R} \$ 260,00$ \\
\hline 5 & $\mathrm{R} \$ 0,00$ & $\mathrm{R} \$ 200,00$ & $\mathrm{R} \$ 30,00$ & $\mathrm{R} \$ 230,00$ \\
\hline
\end{tabular}

Tabela 2.8: solução do exemplo 2.4.2 
Exemplo 2.4.3 - Construa a planilha de amortização pelo SAC de uma dívida de $\mathrm{R} \$ 3000,00$ em 8 pagamentos mensais, com juros de $10 \%$ a.m.

Apresentamos a tabela 2.9, solução do exemplo 2.4.3:

\begin{tabular}{|c|c|c|c|c|}
\hline $\begin{array}{c}\text { Períodos } \\
(\text { meses })\end{array}$ & $\begin{array}{c}\text { Saldo devedor } \\
(\mathrm{R} \$)\end{array}$ & $\begin{array}{c}\text { Amortização } \\
(\mathrm{R} \$)\end{array}$ & $\begin{array}{c}\text { Juros } \\
(\mathrm{R} \$)\end{array}$ & $\begin{array}{c}\text { Prestação } \\
(\mathrm{R} \$)\end{array}$ \\
\hline 0 & $\mathrm{R} \$ 3.000,00$ & & & \\
\hline 1 & $\mathrm{R} \$ 2.625,00$ & $\mathrm{R} \$ 375,00$ & $\mathrm{R} \$ 300,00$ & $\mathrm{R} \$ 675,00$ \\
\hline 2 & $\mathrm{R} \$ 2.250,00$ & $\mathrm{R} \$ 375,00$ & $\mathrm{R} \$ 262,50$ & $\mathrm{R} \$ 637,50$ \\
\hline 3 & $\mathrm{R} \$ 1.875,00$ & $\mathrm{R} \$ 375,00$ & $\mathrm{R} \$ 225,00$ & $\mathrm{R} \$ 600,00$ \\
\hline 4 & $\mathrm{R} \$ 1.500,00$ & $\mathrm{R} \$ 375,00$ & $\mathrm{R} \$ 187,50$ & $\mathrm{R} \$ 562,50$ \\
\hline 5 & $\mathrm{R} \$ 1.125,00$ & $\mathrm{R} \$ 375,00$ & $\mathrm{R} \$ 150,00$ & $\mathrm{R} \$ 525,00$ \\
\hline 6 & $\mathrm{R} \$ 750,00$ & $\mathrm{R} \$ 375,00$ & $\mathrm{R} \$ 112,50$ & $\mathrm{R} \$ 487,50$ \\
\hline 7 & $\mathrm{R} \$ 375,00$ & $\mathrm{R} \$ 375,00$ & $\mathrm{R} \$ 75,00$ & $\mathrm{R} \$ 450,00$ \\
\hline 8 & $\mathrm{R} \$ 0,00$ & $\mathrm{R} \$ 375,00$ & $\mathrm{R} \$ 37,5$ & $\mathrm{R} \$ 412,50$ \\
\hline
\end{tabular}

Tabela 2.9: solução do exemplo 2.4.3

Exemplo 2.4.4 - Uma pessoa tomou um financiamento de $\mathrm{R} \$ 35000,00$ para ser pago em 180 meses, com juros de 1\% a.m. pelo sistema SAC. Determine:

a) O valor da centésima prestação.

Considerando $\mathrm{PV}=35000, \mathrm{n}=180, \mathrm{t}=100$ e $\mathrm{i}=0,01$, temos:

$P M T=\frac{P V}{n} \cdot(1+(n-t+1) \cdot i)=\frac{35000}{180} \cdot(1+(180-100+1) \cdot 0,01)=351,94$

Logo, o valor da $100^{\mathrm{a}}$ prestação será $\mathrm{R} \$ 351,94$.

b) O saldo devedor nessa época.

Apresentamos a solução de duas formas distintas.

A primeira é dada pela fórmula já trabalhada:

$S D=P V-\frac{P V}{n} \cdot t=35000-\frac{35000}{180} \cdot 100=15555,56$

A outra forma seria dada pelo produto da quantidade de prestações não pagas pelo valor da amortização:

$S D=\frac{P V}{n} \cdot(n-t)=\frac{35000}{180} \cdot(180-100)=15555,56$

Portanto, o saldo devedor é de $\mathrm{R} \$ 15555,56$.

\subsubsection{Sistema de amortização francesa (SAF)}

Segundo Assaf (2012), o sistema de amortização francesa (SAF) ou sistema de prestação constante (SPC) ou ainda tabela PRICE é amplamente adotado no mercado financeiro do Brasil e estipula que as prestações devem ser iguais.

Os juros, por incidirem sobre o saldo devedor, são decrescentes, enquanto as parcelas de amortização assumem valores crescentes. 
Um exemplo de aplicação do SPC é na concessão de um CDC (Crédito direto ao consumidor).

Segundo Iezzi (2004), consideremos um valor financiado V que deve ser pago em prestações iguais de valor $\mathrm{R}$ nas datas $1,2,3, \ldots, \mathrm{n}$ e suponhamos que a taxa de juros compostos cobrada no financiamento seja i por período de tempo.

Chamamos esse conjunto de sequencia uniforme de pagamentos e podemos indicar o valor atual das prestações $\mathrm{V}$, à taxa i, por:

$$
V=\frac{R}{(1+i)^{1}}+\frac{R}{(1+i)^{2}}+\frac{R}{(1+i)^{3}}+\ldots++\frac{R}{(1+i)^{n}}
$$

Considerando que o $2^{\circ}$ membro desta equação é a soma dos termos de uma PG finita, cuja razão é $q=\frac{1}{1+i}$ e cujo $1^{\circ}$ termo é $a_{1}=\frac{R}{1+i}$, podemos aplicar a já conhecida fórmula da soma dos n primeiros termos de uma PG finita, dada por:

$$
S_{n}=\frac{a_{1} \cdot\left(q^{n}-1\right)}{q-1}
$$

Assim, temos:

$$
V=\frac{\frac{R}{1+i} \cdot\left[\frac{1}{(1+i)^{n}}-1\right]}{\frac{1}{1+i}-1}=R \cdot \frac{\frac{1}{1+i} \cdot\left[\frac{1-(1+i)^{n}}{(1+i)^{n}}\right]}{\frac{1-(1+i)}{1+i}}=R \cdot \frac{\frac{1-(1+i)^{n}}{(1+i)^{n}}}{-i}
$$

E, finalmente:

$$
V=R \cdot \frac{(1+i)^{n}-1}{(1+i)^{n} \cdot i} \text { ou } V=R \cdot \frac{\left.\left[1-(1+i)^{-n}\right)\right]}{i}
$$

Concluímos então que essa é a fórmula que relaciona o valor atual com a prestação, taxa de juros e números de prestações.

Diante disso, o valor da prestação pode ser obtido por:

$$
R=V \cdot \frac{i}{\left[1-(1+i)^{-n}\right]}
$$

Consideremos o exemplo 2.4.1. A tabela 2.10 a seguir indica o cenário do sistema de prestações constantes.

No caso,

$$
R=100000 \cdot \frac{0,140175}{\left[1-(1+0,140175)^{-10}\right]}=\frac{100000}{5,212555}=\mathrm{R} \$ 19184,45 .
$$

Os juros correspondem ao produto do saldo devedor pela taxa e a amortização é a diferença entre a prestação e os juros. 


\begin{tabular}{|c|c|c|c|c|}
\hline $\begin{array}{c}\text { Períodos } \\
\text { (semestres) }\end{array}$ & $\begin{array}{c}\text { Saldo devedor } \\
(\mathrm{R} \$)\end{array}$ & $\begin{array}{c}\text { Amortização } \\
(\mathrm{R} \$)\end{array}$ & $\begin{array}{c}\text { Juros } \\
(\mathrm{R} \$)\end{array}$ & $\begin{array}{c}\text { Prestação } \\
(\mathrm{R} \$)\end{array}$ \\
\hline 0 & $\mathrm{R} \$ 100.000,00$ & & & \\
\hline 1 & $\mathrm{R} \$ 94.833,05$ & $\mathrm{R} \$ 5.166,95$ & $\mathrm{R} \$ 14.017,50$ & $\mathrm{R} \$ 19.184,45$ \\
\hline 2 & $\mathrm{R} \$ 88.941,82$ & $\mathrm{R} \$ 5.891,23$ & $\mathrm{R} \$ 13.293,22$ & $\mathrm{R} \$ 19.184,45$ \\
\hline 3 & $\mathrm{R} \$ 82.224,79$ & $\mathrm{R} \$ 6.717,03$ & $\mathrm{R} \$ 12.467,42$ & $\mathrm{R} \$ 19.184,45$ \\
\hline 4 & $\mathrm{R} \$ 74.566,20$ & $\mathrm{R} \$ 7.658,59$ & $\mathrm{R} \$ 11.525,86$ & $\mathrm{R} \$ 19.184,45$ \\
\hline 5 & $\mathrm{R} \$ 65.834,07$ & $\mathrm{R} \$ 8.732,13$ & $\mathrm{R} \$ 10.452,32$ & $\mathrm{R} \$ 19.184,45$ \\
\hline 6 & $\mathrm{R} \$ 55.877,91$ & $\mathrm{R} \$ 9.956,16$ & $\mathrm{R} \$ 9.222,29$ & $\mathrm{R} \$ 19.184,45$ \\
\hline 7 & $\mathrm{R} \$ 44.526,15$ & $\mathrm{R} \$ 11.351,76$ & $\mathrm{R} \$ 7.832,69$ & $\mathrm{R} \$ 19.184,45$ \\
\hline 8 & $\mathrm{R} \$ 31.583,15$ & $\mathrm{R} \$ 12.943,00$ & $\mathrm{R} \$ 6.241,45$ & $\mathrm{R} \$ 19.184,45$ \\
\hline 9 & $\mathrm{R} \$ 16.825,87$ & $\mathrm{R} \$ 14.757,28$ & $\mathrm{R} \$ 4.427,17$ & $\mathrm{R} \$ 19.184,45$ \\
\hline 10 & $\mathrm{R} \$ 0,00$ & $\mathrm{R} \$ 16.825,88$ & $\mathrm{R} \$ 2.358,57$ & $\mathrm{R} \$ 19.184,45$ \\
\hline
\end{tabular}

Tabela 2.10: Exemplo 2.4.1 pago pelo SPC em 10 prestações semestrais, sem carência

Ao se supor uma carência de 2 anos (contada a partir do final do primeiro semestre), por exemplo, dois cenários podem ocorrer:

a) Os juros são pagos durante a carência;

b) Os juros são capitalizados e acrescidos ao saldo devedor gerando um fluxo de amortizações de maior valor.

Os quadros apresentados a seguir ilustram as situações, respectivamente:

a) A tabela 2.11 apresenta o SPC com carência (2 anos) e Pagamento periódico dos juros

\begin{tabular}{|c|c|c|c|c|}
\hline $\begin{array}{c}\text { Períodos } \\
\text { (semestres })\end{array}$ & $\begin{array}{c}\text { Saldo devedor } \\
(\mathrm{R} \$)\end{array}$ & $\begin{array}{c}\text { Amortização } \\
(\mathrm{R} \$)\end{array}$ & $\begin{array}{c}\text { Juros } \\
(\mathrm{R} \$)\end{array}$ & $\begin{array}{c}\text { Prestação } \\
(\mathrm{R} \$)\end{array}$ \\
\hline 0 & $\mathrm{R} \$ 100.000,00$ & & & \\
\hline 1 & $\mathrm{R} \$ 100.000,00$ & & $\mathrm{R} \$ 14.017,50$ & $\mathrm{R} \$ 14.017,50$ \\
\hline 2 & $\mathrm{R} \$ 100.000,00$ & & $\mathrm{R} \$ 14.017,50$ & $\mathrm{R} \$ 14.017,50$ \\
\hline 3 & $\mathrm{R} \$ 100.000,00$ & & $\mathrm{R} \$ 14.017,50$ & $\mathrm{R} \$ 14.017,50$ \\
\hline 4 & $\mathrm{R} \$ 100.000,00$ & & $\mathrm{R} \$ 14.017,50$ & $\mathrm{R} \$ 14.017,50$ \\
\hline 5 & $\mathrm{R} \$ 94.833,05$ & $\mathrm{R} \$ 5.166,95$ & $\mathrm{R} \$ 14.017,50$ & $\mathrm{R} \$ 19.184,45$ \\
\hline 6 & $\mathrm{R} \$ 88.941,82$ & $\mathrm{R} \$ 5.891,23$ & $\mathrm{R} \$ 13.293,22$ & $\mathrm{R} \$ 19.184,45$ \\
\hline 7 & $\mathrm{R} \$ 82.224,79$ & $\mathrm{R} \$ 6.717,03$ & $\mathrm{R} \$ 12.467,42$ & $\mathrm{R} \$ 19.184,45$ \\
\hline 8 & $\mathrm{R} \$ 74.566,20$ & $\mathrm{R} \$ 7.658,59$ & $\mathrm{R} \$ 11.525,86$ & $\mathrm{R} \$ 19.184,45$ \\
\hline 9 & $\mathrm{R} \$ 65.834,07$ & $\mathrm{R} \$ 8.732,13$ & $\mathrm{R} \$ 10.452,32$ & $\mathrm{R} \$ 19.184,45$ \\
\hline 10 & $\mathrm{R} \$ 55.877,91$ & $\mathrm{R} \$ 9.956,16$ & $\mathrm{R} \$ 9.222,29$ & $\mathrm{R} \$ 19.184,45$ \\
\hline 11 & $\mathrm{R} \$ 44.526,15$ & $\mathrm{R} \$ 11.351,76$ & $\mathrm{R} \$ 7.832,69$ & $\mathrm{R} \$ 19.184,45$ \\
\hline 12 & $\mathrm{R} \$ 31.583,15$ & $\mathrm{R} \$ 12.943,00$ & $\mathrm{R} \$ 6.241,45$ & $\mathrm{R} \$ 19.184,45$ \\
\hline 13 & $\mathrm{R} \$ 16.825,87$ & $\mathrm{R} \$ 14.757,28$ & $\mathrm{R} \$ 4.427,17$ & $\mathrm{R} \$ 19.184,45$ \\
\hline 14 & $\mathrm{R} \$ 0,00$ & $\mathrm{R} \$ 16.825,88$ & $\mathrm{R} \$ 2.358,57$ & $\mathrm{R} \$ 19.184,45$ \\
\hline \multicolumn{3}{|l|}{}
\end{tabular}

Tabela 2.11: SPC com carência onde os juros são pagos durante a carência 
b) A tabela 2.12 apresenta o SPC com carência (2 anos) e capitalização acrescida ao saldo devedor gerando um fluxo de amortizações de maior valor:

\begin{tabular}{|c|c|c|c|c|}
\hline $\begin{array}{c}\text { Períodos } \\
\text { (semestres) }\end{array}$ & $\begin{array}{c}\text { Saldo devedor } \\
(\mathrm{R} \$)\end{array}$ & $\begin{array}{c}\text { Amortização } \\
(\mathrm{R} \$)\end{array}$ & $\begin{array}{c}\text { Juros } \\
(\mathrm{R} \$)\end{array}$ & $\begin{array}{c}\text { Prestação } \\
(\mathrm{R} \$)\end{array}$ \\
\hline 0 & $\mathrm{R} \$ 100.000,00$ & & & \\
\hline 1 & $\mathrm{R} \$ 114.017,50$ & & & \\
\hline 2 & $\mathrm{R} \$ 129.999,90$ & & & \\
\hline 3 & $\mathrm{R} \$ 148.222,64$ & & & \\
\hline 4 & $\mathrm{R} \$ 169.000,00$ & & & \\
\hline 5 & $\mathrm{R} \$ 160.267,86$ & $\mathrm{R} \$ 8.732,15$ & $\mathrm{R} \$ 23.689,58$ & $\mathrm{R} \$ 32.421,72$ \\
\hline 6 & $\mathrm{R} \$ 150.311,68$ & $\mathrm{R} \$ 9.956,17$ & $\mathrm{R} \$ 22.465,55$ & $\mathrm{R} \$ 32.421,72$ \\
\hline 7 & $\mathrm{R} \$ 138.959,90$ & $\mathrm{R} \$ 11.351,78$ & $\mathrm{R} \$ 21.069,94$ & $\mathrm{R} \$ 32.421,72$ \\
\hline 8 & $\mathrm{R} \$ 126.016,89$ & $\mathrm{R} \$ 12.943,02$ & $\mathrm{R} \$ 19.478,70$ & $\mathrm{R} \$ 32.421,72$ \\
\hline 9 & $\mathrm{R} \$ 111.259,58$ & $\mathrm{R} \$ 14.757,30$ & $\mathrm{R} \$ 17.664,42$ & $\mathrm{R} \$ 32.421,72$ \\
\hline 10 & $\mathrm{R} \$ 94.433,67$ & $\mathrm{R} \$ 16.825,91$ & $\mathrm{R} \$ 15.595,81$ & $\mathrm{R} \$ 32.421,72$ \\
\hline 11 & $\mathrm{R} \$ 75.249,20$ & $\mathrm{R} \$ 19.184,48$ & $\mathrm{R} \$ 13.237,24$ & $\mathrm{R} \$ 32.421,72$ \\
\hline 12 & $\mathrm{R} \$ 53.375,53$ & $\mathrm{R} \$ 21.873,66$ & $\mathrm{R} \$ 10.548,06$ & $\mathrm{R} \$ 32.421,72$ \\
\hline 13 & $\mathrm{R} \$ 28.435,73$ & $\mathrm{R} \$ 24.919,80$ & $\mathrm{R} \$ 7.481,92$ & $\mathrm{R} \$ 32.421,72$ \\
\hline 14 & $\mathrm{R} \$ 0,00$ & $\mathrm{R} \$ 28.435,74$ & $\mathrm{R} \$ 3.985,98$ & $\mathrm{R} \$ 32.421,72$ \\
\hline
\end{tabular}

Tabela 2.12: SPC com carência onde os juros são capitalizados e acrescidos ao saldo devedor gerando um fluxo de amortizações de maior valor

Exemplo 2.4.5 - Um banco concedeu um empréstimo para uma pessoa adquirir um carro. O pagamento deveria ser feito em 12 prestações mensais de $\mathrm{R} \$ 1400,00$ cada uma, sem entrada. Qual o valor do empréstimo sabendo-se que a taxa de juros compostos cobrada pelo banco foi de $3 \%$ a.m.?

Neste caso temos $\mathrm{R}=\mathrm{R} \$ 1400,00, \mathrm{n}=12$ e $\mathrm{i}=0,03$ a. $\mathrm{m}$.

O valor do empréstimo corresponde ao valor atual desses pagamentos, que, conforme a fórmula dada, vale:

$$
V=1400 \cdot \frac{(1,03)^{12}-1}{(1,03)^{12} \cdot 0,03}=13935,61
$$

Logo, o valor emprestado pelo banco foi de $\mathrm{R} \$ 13935,61$.

Exemplo 2.4.6 - Uma loja vende uma televisão por $\mathrm{R} \$ 1200,00$ à vista ou financia essa quantia em 5 prestações iguais sem entrada. Qual o valor de cada prestação se a taxa de juros compostos cobrada for de $2,5 \%$ a.m.?

Neste caso temos $\mathrm{V}=\mathrm{R} \$ 1200,00, \mathrm{n}=5$ e $\mathrm{i}=0,025$ a.m.

Daí:

$$
R=1200 \cdot \frac{0,025}{\left[1-(1+0,025)^{-5}\right]}=258,30
$$


Assim, cada prestação mensal deve valer $\mathrm{R} \$ 258,30$.

Exemplo 2.4.7 - Qual seria o valor de cada prestação no exemplo anterior se a loja cobrasse uma entrada à vista de $\mathrm{R} \$ 300,00$ ?

Neste caso o valor financiado V seria $\mathrm{R} \$ 900,00$ (1200 - 300). Assim, V $=\mathrm{R} \$ 900,00$, $\mathrm{n}=5$ e $\mathrm{i}=0,025$ a.m.. Logo

$$
R=900 \cdot \frac{0,025}{\left[1-(1+0,025)^{-5}\right]}=193,72
$$

Assim, o valor de cada prestação será $\mathrm{R} \$ 193,72$.

\subsection{Montante de uma sequência uniforme de depósitos}

Segundo Bruni e Famá (2003), entende-se como sequência uniforme de depósitos o conjunto de pagamentos de valor nominal igual, que se encontram dispostos em períodos de tempo constantes.

Exemplo 2.5.1 - Suponhamos que uma pessoa deposite mensalmente R \$ 500,00 num fundo de investimento que renda 1,5\% a.m.. Se ela quiser saber seu montante logo após ter feito o $20^{\circ}$ depósito, podemos achar o montante de cada depósito e, em seguida, soma-lo para obter o resultado desejado. A soma dos montantes de cada depósito recebe o nome de montante de uma sequência uniforme de depósitos.

Segundo Iezzi (2003), obtemos o montante do último depósito na data n por:

$$
M_{n}=\frac{500}{(1+0,015)^{19}}+\frac{500}{(1+0,015)^{18}}+\frac{500}{(1+0,015)^{17}}+\ldots+\frac{500}{(1+0,015)^{1}}+\frac{500}{(1+0,015)^{0}}
$$

Generalizando:

$$
M_{n}=R \cdot(1+i)^{n-1}+R \cdot(1+i)^{n-2}+R \cdot(1+i)^{n-3}+\ldots+R \cdot(1+i)^{n-n}
$$

onde $\mathrm{M}$ é o montante; $\mathrm{R}$ é o valor depositado mensalmente; I é a taxa de juros; $\mathrm{n}$ é o prazo passado até o último depósito.

Porém, o segundo membro dessa equação constitui, claramente, uma progressão geométrica cuja razão vale $q=(1+i)^{-1}=\frac{1}{1+i}$ e cujo $1^{\circ}$ termo é $a_{1}=R \cdot(1+i)^{n-1}$. Ao aplicarmos a soma dos termos de uma PG finita, temos:

$$
M=\frac{R \cdot 1+i^{n-1} \cdot\left[\frac{1}{(1+i)^{n}}-1\right]}{\frac{1}{1+i}-1}=R \cdot \frac{\frac{1}{1+i}-(1+i)^{n-1}}{\frac{-i}{1+i}}=R \cdot \frac{\frac{1-(1+i)^{n}}{(1+i)}}{\frac{-i}{1+i}}
$$

Daí: 


$$
M=\frac{R \cdot\left(1-1+i^{n}\right)}{-i}=R \cdot \frac{(1+i)^{n}-1}{i}
$$

Voltando ao nosso exemplo, temos:

$$
M=500 \cdot \frac{(1+0,015)^{20}-1}{0,015}=11561,83
$$

Portanto, o montante logo após o $20^{\circ}$ depósito é $\mathrm{R} \$ 11561,83$.

O cálculo desse montante pode ser verificado ainda na tabela 2.13:

\begin{tabular}{|c|c|c|c|}
\hline $\begin{array}{c}\text { Períodos } \\
\text { (meses) }\end{array}$ & $\begin{array}{c}\text { Valor depositado } \\
(\mathrm{R} \$)\end{array}$ & $\begin{array}{c}\text { Juros } \\
(\mathrm{R} \$)\end{array}$ & $\begin{array}{c}\text { Montante no 20 } \\
\text { depósito }(\mathrm{R} \$)\end{array}$ \\
\hline 0 & $\mathrm{R} \$ 500,00$ & $\mathrm{R} \$ 163,48$ & $\mathrm{R} \$ 663,48$ \\
\hline 1 & $\mathrm{R} \$ 500,00$ & $\mathrm{R} \$ 153,67$ & $\mathrm{R} \$ 653,67$ \\
\hline 2 & $\mathrm{R} \$ 500,00$ & $\mathrm{R} \$ 144,01$ & $\mathrm{R} \$ 644,01$ \\
\hline 3 & $\mathrm{R} \$ 500,00$ & $\mathrm{R} \$ 134,49$ & $\mathrm{R} \$ 634,49$ \\
\hline 4 & $\mathrm{R} \$ 500,00$ & $\mathrm{R} \$ 125,12$ & $\mathrm{R} \$ 625,12$ \\
\hline 5 & $\mathrm{R} \$ 500,00$ & $\mathrm{R} \$ 115,88$ & $\mathrm{R} \$ 615,88$ \\
\hline 6 & $\mathrm{R} \$ 500,00$ & $\mathrm{R} \$ 106,78$ & $\mathrm{R} \$ 606,78$ \\
\hline 7 & $\mathrm{R} \$ 500,00$ & $\mathrm{R} \$ 97,81$ & $\mathrm{R} \$ 597,81$ \\
\hline 8 & $\mathrm{R} \$ 500,00$ & $\mathrm{R} \$ 88,97$ & $\mathrm{R} \$ 588,97$ \\
\hline 9 & $\mathrm{R} \$ 500,00$ & $\mathrm{R} \$ 80,27$ & $\mathrm{R} \$ 580,27$ \\
\hline 10 & $\mathrm{R} \$ 500,00$ & $\mathrm{R} \$ 71,69$ & $\mathrm{R} \$ 571,69$ \\
\hline 11 & $\mathrm{R} \$ 500,00$ & $\mathrm{R} \$ 63,25$ & $\mathrm{R} \$ 563,25$ \\
\hline 12 & $\mathrm{R} \$ 500,00$ & $\mathrm{R} \$ 54,92$ & $\mathrm{R} \$ 554,92$ \\
\hline 13 & $\mathrm{R} \$ 500,00$ & $\mathrm{R} \$ 46,72$ & $\mathrm{R} \$ 546,72$ \\
\hline 14 & $\mathrm{R} \$ 500,00$ & $\mathrm{R} \$ 38,64$ & $\mathrm{R} \$ 538,64$ \\
\hline 15 & $\mathrm{R} \$ 500,00$ & $\mathrm{R} \$ 30,68$ & $\mathrm{R} \$ 530,68$ \\
\hline 16 & $\mathrm{R} \$ 500,00$ & $\mathrm{R} \$ 22,84$ & $\mathrm{R} \$ 522,84$ \\
\hline 17 & $\mathrm{R} \$ 500,00$ & $\mathrm{R} \$ 15,11$ & $\mathrm{R} \$ 515,11$ \\
\hline 18 & $\mathrm{R} \$ 500,00$ & $\mathrm{R} \$ 7,50$ & $\mathrm{R} \$ 507,50$ \\
\hline 19 & $\mathrm{R} \$ 500,00$ & $\mathrm{R} \$ 0,00$ & $\mathrm{R} \$ 500,00$ \\
\hline & & & \\
\hline
\end{tabular}

Tabela 2.13: Montante obtido por 20 depósitos mensais de $\mathrm{R} \$ 500,00$ a uma taxa de $1,5 \%$ a.m.

Exemplo 2.5.2 - Uma pessoa deposita mensalmente $\mathrm{R} \$ 600,00$ num fundo que rende $1 \%$ a.m.. Qual será o seu montante imediatamente após o $30^{\circ}$ depósito?

$$
M=600 \cdot \frac{(1+0,01)^{30}-1}{0,01}=20870,93
$$

Diante disso, o montante logo após o $30^{\circ}$ depósito é $\mathrm{R} \$ 20870,93$. 


\subsubsection{Quanto devo depositar por mês para ter uma certa apo- sentadoria complementar?}

Segundo Zentgraf e Gianbiagi (2010), a melhor forma de entender o que vai ser explicado a seguir é começar pensando o que aconteceria se a aposentadoria complementar fosse resultado da acumulação prévia de alguma poupança em um sistema financeiro sem juros, no qual os bancos serviriam apenas para guardar dinheiro protegendo este do risco de roubo. Nesse mundo simplificado, as pessoas depositariam periodicamente uma contribuição C por um prazo de tempo T. Decorrido esse prazo e supondo ausência de inflação, as mesmas pessoas fariam retiradas correspondentes a uma aposentadoria complementar A, que seria recebida por um período de duração N. Na ausência de perdas ou ganhos para o banco, os dois termos da equação teriam de se igualar, de modo que:

$$
C \cdot T=N \cdot A
$$

Isso faria do cálculo da aposentadoria complementar A algo trivial, dada por:

$$
A=\frac{C \cdot T}{N}
$$

Em outras palavras, a aposentadoria complementar, em um mundo sem inflação e sem juros, seria tanto maior quanto maiores fossem a contribuição feita e a relação entre o número de anos de contribuição e de retirada de recursos de uma conta financeira.

Exemplo 2.5.3 - Se alguém contribuísse com $\mathrm{R} \$ 500,00$ por mês durante 40 anos e depois utilizasse os recursos da aposentadoria complementar por mais 20 anos, o valor desta poderia ser de $A=\frac{500 \cdot 40}{20}=1000$. Porém, esse não se trata do mundo real.

Na presença de juros - e continuando a raciocinar como se não houvesse inflação -, as coisas se complicam um pouco, embora isso seja bom do ponto de vista de quem contribui para complementar sua aposentadoria. Por um lado, o cálculo é mais complexo. Por outro, a pessoa sai ganhando porque o dinheiro aplicado rende de modo que, para ter a mesma aposentadoria complementar, ela pode contribuir com um valor inferior ao que resultaria do cálculo da fórmula anterior.

Para fazer o cálculo da nova situação, vamos voltar à fórmula obtida na tabela price:

$$
V=R \cdot \frac{(1+i)^{n}-1}{(1+i)^{n} \cdot i}
$$

Que, adaptada a situação atual, ficaria assim:

$$
P=A \cdot \frac{(1+i)^{n}-1}{(1+i)^{n} \cdot i} \text { e } A=P \cdot \frac{(1+i)^{n} \cdot i}{(1+i)^{n}-1}
$$

Em que P é o valor presente de um compromisso financeiro que gera um comprometimento de renda A. 
Por analogia, podemos entender que o capital que é preciso acumular previamente ao recebimento de uma aposentadoria complementar como sendo aquele que será igual ao valor presente dos fluxos de recebimentos futuros dessa aposentadoria complementar. Se a denominarmos A, o valor do capital acumulado até o momento T a partir do qual se dá a retirada da ativa é, substituindo a letra $\mathrm{P}$ por $K_{T}$ ficaria:

$$
K_{T}=A \cdot \frac{(1+i)^{n}-1}{(1+i)^{n} \cdot i}
$$

onde $K_{T}$ é o capital acumulado até T para fazer jus aos valores de A a serem recebidos, i é a taxa de juros e n é o período do recebimento de A.

O valor de $\mathrm{K}$ é expresso em T, mas para torná-lo comparável com o valor presente das contribuições no momento inicial da vida ativa de um indivíduo é preciso trazê-lo ao momento 0 da análise, conforme:

$$
K_{0}=\frac{K_{T}}{(1+i)^{T}}
$$

onde 0 se refere ao momento do início da vida ativa do indivíduo. Assume-se que o filiado a um fundo de aposentadoria contribui por $\mathrm{T}$ anos e recebe a aposentadoria complementar por $\mathrm{n}$ anos.

Por sua vez, o valor da contribuição C que o indivíduo deve fazer ao longo de sua vida ativa, substituindo $\mathrm{A}$ por $\mathrm{C}$ na fórmula é:

$$
C=K_{0} \cdot \frac{(1+i)^{T} \cdot i}{(1+i)^{T}-1}
$$

onde T é o período de aportes contributivos e $K_{0}$ é o valor do capital que se acumula na fase ativa, expressos do momento inicial, quando começa a fase contributiva. Considerase, para facilitar, que a taxa de juros incidente sobre o capital acumulado é a mesma na fase ativa $\mathrm{T}$ e na inativa N. Fazendo a substituições temos que:

$$
C=A \cdot\left[\frac{(1+i)^{n}-1}{(1+i)^{n} \cdot\left[(1+i)^{T}-1\right]}\right]
$$

Em outras palavras, a partir de T sucessivas contribuições C, a pessoa acumula ao longo de um certo número de períodos, e com base em uma taxa de juros i, um capital que no momento T atinge o valor $K_{T}$. Esse valor, na fase de desacumulação, tem de cobrir a aposentadoria complementar mantida por certo número de períodos $\mathrm{n}$ e, portanto, corresponde a n retiradas no valor de A. Tanto na fase de contribuição e capitalização como na fase posterior de retiradas e descapitalização, a taxa de juros i é a mesma e pressupõe que o intervalo entre as $\mathrm{C}$ contribuições sucessivas seja idêntico ao intervalo entre as $n$ retiradas.

Para verificarmos o impacto gerado na contribuição quando introduzimos uma taxa de juros, o exemplo anterior, em que foi preciso contribuir mensalmente com $\mathrm{R} \$ 500,00$ durante 40 anos para se conseguir 20 anos de retiradas mensais de $\mathrm{R} \$ 1000,00$, será aqui revisto, assumindo-se uma taxa de juros de 0,5\% a.m.. Neste caso, n corresponderá a 240 meses, T a 480 meses e A a R $\$ 1000,00$. Jogando na fórmula: 


$$
C=1000 \cdot\left[\frac{(1,005)^{240}-1}{(1,005)^{240} \cdot\left[(1,005)^{480}-1\right]}\right]=\mathrm{R} \$ 70,09 .
$$

em vez dos $\mathrm{R} \$ 500,00$ do cálculo sem juros.

Posto de outra forma e confirmando o que já foi comentado, a existência da taxa de juros, ainda que complique o cálculo, evidencia as vantagens da acumulação de capital em um ambiente em que o sacrifício da poupança tem sua devida recompensa.

Podemos simplificar a situação acima usando a taxa equivalente anual, o que revela um auxílio importante nas projeções de longo prazo, quando é usual trabalharmos com taxas anuais. No caso em questão, 0,5\% mensais correspondem a 6,167781\% anuais, e assim faremos $\mathrm{N}=20$ anos, $\mathrm{T}=40$ anos, conforme segue:

$$
C=1000 \cdot\left[\frac{(1,0617781)^{20}-1}{(1,0617781)^{20} \cdot\left[(1,0617781)^{40}-1\right]}\right]=\mathrm{R} \$ 70,09 .
$$

Invertendo os termos da equação, se conhecida a contribuição pode-se calcular endogenamente a aposentadoria complementar disso resultante. Com os dados da simulação anterior, por exemplo, poderíamos querer saber qual a aposentadoria complementar a que um indivíduo teria direito se, durante 40 anos, tivesse contribuído $\mathrm{R} \$ 500,00$ mensais e, desde que utilizemos todas as casas decimais nos cálculos intermediários, chegamos a $\mathrm{R} \$ 7133,83$, conforme segue:

$$
500=A \cdot\left[\frac{(1,0617781)^{20}-1}{(1,0617781)^{20} \cdot\left[(1,0617781)^{40}-1\right]}\right]=A \cdot 0,070088587
$$

logo:

$$
A=\frac{500}{0,070088587}=\mathrm{R} \$ 7133,83 .
$$

Assume-se que o início da contribuição conhecida com o começo da vida ativa da pessoa, mas o raciocínio vale também para o caso de uma contribuição se dê depois de a pessoa ter começado a trabalhar. Dada a aposentadoria complementar desejada A e a taxa de juros, além do tempo de contribuição e o número de anos do recebimento da aposentadoria complementar é possível calcular o valor da contribuição requerida C.

Exemplo 2.5.3 - Suponha uma pessoa que comece a trabalhar e contribuir com 20 anos e vive até 80 anos. O valor de n, em função da premissa explicitada, é igual a (60 - T). Ou seja, 35 anos de contribuição geram um usufruto de aposentadoria complementar de 25 anos e 40 anos de contribuição geram uma aposentadoria complementar durante 20 anos, e assim sucessivamente.

Trazendo um pouco mais para a vida real, passaremos agora a adotar uma taxa real de juros, já descontada dos efeitos da inflação, já estudada anteriormente. Nas figuras 2.1 e 2.2 seguintes, tanto as aposentadorias quanto as contribuições mensais estão expressas em bases mensais. Adotaremos então a hipótese de juros reais de $3 \%$ a.a. e $4 \%$ a.a. Naturalmente, ao compararmos os resultados, concluiremos que o valor da contribuição é uma função direta da aposentadoria desejada e uma função inversa do tempo de contribuição e da taxa de juros. 


\begin{tabular}{|c|c|c|c|c|c|}
\hline \multicolumn{2}{|c|}{ Valor da contri buição para diferentes níveis de aposentadoria complementar com taxa anual i de $3 \%$} \\
\hline \multicolumn{2}{|c|}{} & \multicolumn{3}{c|}{ Val ores da aposentadoria complementar (R\$) } \\
\cline { 3 - 6 } & $\mathbf{N}=3 \%$ & 1000 & 2000 & 3000 & 4000 \\
\hline \multirow{2}{*}{$\begin{array}{c}\text { Valores de T } \\
\text { (anos) }\end{array}$} & 35 & 288,00 & 576,00 & 864,00 & 1152,00 \\
\cline { 2 - 6 } & 40 & 197,31 & 394,62 & 591,93 & 789,24 \\
\cline { 2 - 6 } & 45 & 128,75 & 257,50 & 386,25 & 515,00 \\
\hline
\end{tabular}

Figura 2.1: valor da contribuição para diferentes níveis de aposentadoria complementar com taxa de $3 \%$ a.a.

Com uma taxa real de juros de $3 \%$, quem quiser, por exemplo, contribuir dos 20 anos aos 55 anos para uma aposentadoria complementar de $\mathrm{R} \$ 1000,00$, para se aposentar e receber o benefício da renda complementar por 25 anos, dos 56 aos 80 anos, deve contribuir mensalmente com $\mathrm{R} \$ 288,00$. Já quem quiser uma aposentadoria complementar de $R \$ 4000,00$ a ser recebida durante 25 anos deveria contribuir com $R \$$ 1152,00 mensais. Naturalmente, com maior tempo contribuitivo e menor número de anos de recebimento de benefício, as exigências de contribuição são menores. Por exemplo, quem contribuir durante 45 anos, deveria contribuir, para a mesma aposentadoria de $\mathrm{R} \$ 1000,00$, com $\mathrm{R} \$ 128,75$ e não com $\mathrm{R} \$ 288,00$.

\begin{tabular}{|c|c|c|c|c|c|}
\hline \multicolumn{2}{|c|}{ Valor da contri buição para diferentes niveis de aposentadoria complementar com taxa anual i de $4 \%$} & N=60-T \\
\hline \multicolumn{2}{|c|}{} & \multicolumn{3}{|c|}{ Valores da aposentadoria complementar (R\$) } \\
\cline { 3 - 6 } & 1000 & 2000 & 3000 & 4000 \\
\hline \multirow{2}{*}{$\begin{array}{c}\text { Valores de T } \\
\text { (anos) }\end{array}$} & 35 & 212,11 & 424,22 & 636,33 & 848,44 \\
\cline { 2 - 6 } & 40 & 143,02 & 286,04 & 429,06 & 572,08 \\
\cline { 2 - 6 } & 45 & 91,87 & 183,74 & 275,61 & 367,48 \\
\hline
\end{tabular}

Figura 2.2: valor da contribuição para diferentes níveis de aposentadoria complementar com taxa de $4 \%$ a.a.

Já com uma taxa de juros de 4\%, os valores são menores para cada célula. Para o mesmo caso da aposentadoria complementar de $\mathrm{R} \$ 1000,00$ e 35 anos de contribuição, o requerimento contributivo cede de $\mathrm{R} \$ 288,00$ para $\mathrm{R} \$ 212,11$;

Porém, muita gente espera chegar à meia-idade para começar a se preocupar com o tema da aposentadoria complementar.

Um raciocínio típico por trás dessa atitude é considerar que, ao chegar aos 45/50 anos, muitos adultos podem ter se beneficiado do recebimento de alguma herança e que isso pode gerar uma boa base para entrar com uma joia e receber uma aposentadoria complementar relativamente robusta.

Será que, para valores realistas, isso é correto?

A resposta depende de quanto a pessoa deseja ter de aposentadoria complementar e, naturalmente, do tamanho da herança.

Por exemplo, supondo um indivíduo que deseje aposentadoria complementar $\mathrm{R} \$$ 1000,00 por 25 anos, uma alternativa à contribuição mensal de $\mathrm{R} \$ 288,00$ por 35 anos 
seria ter - não importa como - o saldo de $\mathrm{R} \$ 211815,61$ aos 55 anos em uma conta ou investimento que rendesse $3 \%$ a.a.

Para o caso que acabamos de ilustrar e com a fórmula obtida na tabela price podemos descobrir o valor da aposentadoria complementar A que seria possível a partir de uma taxa de juros e do valor de uma herança $\mathrm{P}$, disponível um período antes da primeira retirada do complemento da aposentadoria, Por exemplo, um capital de $\mathrm{R} \$$ 500 mil depositados hoje a uma taxa real de $3 \%$ a.a. (ou 0,246627\% a.m.) permitirão 15 anos de retiradas mensais no valor de $\mathrm{R} \$ 3443,18$, já a partir do próximo mês, conforme cálculos seguintes:

$$
A=500000 \cdot \frac{(1,00246627)^{180} \cdot 0,00246627}{(1,00246627)^{180}-1}=\mathrm{R} \$ 3443,18
$$

Outros valores quando simulamos taxas de juros anuais de $3 \%$ e $4 \%$, respectivamente, encontram-se nas figuras 2.3 e 2.4 seguintes. Como aqui não pretendemos mostrar a tabela período a período, podemos trabalhar em bases mensais.

\begin{tabular}{|c|c|c|c|c|c|}
\hline \multicolumn{6}{|c|}{$\begin{array}{l}\text { Valor da a posentadoria complementar para diferentes níveis de tempo e aplicação inicial, dada a taxa de } \\
\text { juros ( } \mathbf{R} \text { ) }\end{array}$} \\
\hline \multirow{2}{*}{\multicolumn{2}{|c|}{$\mathrm{i}=3 \%$}} & \multicolumn{4}{|c|}{ Aplicação inicial ( $R \$$ milhares) } \\
\hline & & 500 & 1000 & 1500 & 2000 \\
\hline \multirow{3}{*}{$\begin{array}{c}\text { Valores de N } \\
\text { (anos) }\end{array}$} & 15 & 3443,18 & 6886,36 & 10329,54 & 13772,72 \\
\hline & 20 & 2762,87 & 5525,74 & 8288,61 & 11051,48 \\
\hline & 25 & 2360,54 & 4721,08 & 7081,62 & 9442,16 \\
\hline
\end{tabular}

Figura 2.3: valor da aposentadoria complementar para diferentes níveis de tempo e aplicação inicial numa taxa de $3 \%$ a.a.

\begin{tabular}{|c|c|c|c|c|c|}
\hline \multicolumn{6}{|c|}{$\begin{array}{l}\text { Valor da a posentadoria complementar para diferentes níveis de tempo e aplicação inicial, dada a taxa } \\
\text { juros ( } R \$ \text { ) }\end{array}$} \\
\hline \multirow{2}{*}{\multicolumn{2}{|c|}{$i=4 \%$}} & \multicolumn{4}{|c|}{ Aplicação inicial (R\$ milhares) } \\
\hline & & 500 & 1000 & 1500 & 2000 \\
\hline \multirow{3}{*}{$\begin{array}{c}\text { Valores de N } \\
\text { (anos) }\end{array}$} & 15 & 3680,55 & 7361,10 & 11041,65 & 14722,20 \\
\hline & 20 & 3011,09 & 6022,18 & 9033,27 & 12044,36 \\
\hline & 25 & 2619,48 & 5238,96 & 7858,44 & 10477,92 \\
\hline
\end{tabular}

Figura 2.4: valor da aposentadoria complementar para diferentes níveis de tempo e aplicação inicial numa taxa de $4 \%$ a.a.

Isto é, se for aplicado um patrimônio de $\mathrm{R} \$ 500$ mil por 25 anos, a uma taxa real de juros de 3\%, isso gerará uma aposentadoria complementar de R $\$ 2360,54$. Naturalmente, se o objetivo for fazer retiradas, a partir do mesmo capital, durante apenas 15 anos, o valor do saque mensal é maior: $\mathrm{R} \$ 3443,18$.

Cabe salientar que a situação de cada pessoa definirá se tais valores são satisfatórios ou não. 


\section{Capítulo 3}

\section{Proposta de atividades educacionais}

Após verificação da importância do ensino da Matemática Financeira com base na educação financeira, o que os documentos dos responsáveis pela educação no Brasil orientam a respeito do ensino deste item, faremos algumas sugestões de atividades que contemplam exercícios envolvendo a matemática financeira, além do que é apresentado nos livros didáticos atualmente, que se relacionem ao cotidiano do aluno e também abordem a interdisciplinaridade.

O principal enfoque das atividades é abordar a matemática financeira de maneira mais aplicada, propondo ao aluno uma abordagem que traga significância na vida do aluno.

\subsection{Objetivos}

Estas atividades possuem como principais objetivos:

- Chamar a atenção dos alunos em relação à presença da matemática financeira em seu cotidiano.

- Abordar o ensino da matemática financeira através de situações problema que possuem grande importância para a vida deste aluno.

- Propor atividades que visam motivar os alunos a utilizar o dinheiro de maneira correta e consciente.

O intuito da atividade é fazer com que o aluno sinta que a Matemática Financeira é importante para o seu futuro financeiro e utilize este conhecimento a seu favor.

\subsection{Público-alvo e pré-requisitos}

As atividades propostas neste material são voltadas aos alunos do terceiro ano do ensino médio. Porém, nada impede que estas sejam utilizadas em outras séries, desde 
que alguns pré-requisitos sejam atendidos.

Para que o aluno possa acompanhar de forma satisfatória as atividades propostas neste trabalho é necessário que ele conheça os conceitos básicos de: razão, proporção, porcentagem, juros compostos, progressões aritméticas e geométricas. Como esses assuntos usualmente são abordados no ensino fundamental ou no primeiro ano do ensino médio, não haverá problemas para um aluno do terceiro ano do ensino médio acompanhar as atividades aqui propostas. Porém prevendo que os alunos não tenham visto ou já esquecido estes conceitos é prudente fazer uma revisão dos mesmos durante as atividades propostas.

\subsection{Materiais e tecnologias}

Como a sociedade atual tem uma crescente necessidade da utilização da tecnologia e com a manipulação cada vez mais frequente de aparelhos eletrônicos pelos alunos, é importante que a escola esteja inserida neste contexto social, utilizando estes recursos como forma de auxilio a aprendizagem. A tecnologia deve ser vista como mais um recurso didático para a transmissão do saber. E para isto não basta apenas utilizar a tecnologia, mas sim saber como utilizá-la da maneira mais produtiva em sala de aula. Nesta atividade pretende-se fazer uso da calculadora existente nos computadores das escolas, bem como a utilização das planilhas eletrônicas, bem como telefones celulares, utilizando a tecnologia a favor do aprendizado deste aluno.

\subsection{Recomendações metodológicas}

Para realizar estas atividades, recomenda-se iniciar com uma aula expositiva, seguidos por exemplos e explanação no quadro-negro. Passado este momento, sugere-se dar oportunidade para que os alunos possam questionar o professor sobre eventuais dúvidas, bem como maiores explicações do professor. Neste momento, os alunos que determinarão os caminhos das explicações, pois de acordo com as dúvidas que surgirem, o professor pode abordar pontos que não foram explorados, ou mesmo abordar de uma maneira mais clara os tópicos que não foram totalmente assimilados. Não deve haver pressa em passar para a próxima etapa, pois neste momento, onde o professor mostrase aberto a sanar dúvidas, mesmo que as mais simples, é uma grande oportunidade para que aqueles alunos mais tímidos possam tirar suas dúvidas através das perguntas dos colegas.

Após este importante momento, os exercícios serão feitos pelos alunos de maneira em grupos de, no máximo, cinco alunos, e o professor ficará disponível, passando em todos os grupos auxiliando os alunos em suas principais dificuldades, para depois corrigir as atividades. 
No próximo momento propomos a correção das atividades usando planilha eletrônica para a construção dos cálculos e da resposta final de cada uma das questões.

\subsection{Dificuldades previstas}

Algumas das possíveis dificuldades esperadas pelo professor nesta atividade são:

- o desinteresse por parte de alguns alunos: mesmo com a abordagem do conteúdo feita de uma forma diferente, existe a possibilidade de alunos não se interessarem por este conteúdo por já terem adquirido "antipatia" pela matemática;

- as demonstrações propostas podem ser desinteressantes para os alunos que não possuem afinidade com a matemática;

- a falta de aprendizagem dos pré-requisitos já citados anteriormente pode levar alguns alunos a não conseguirem sequer iniciar as atividades;

- dificuldade no manuseio do computador, do celular e da calculadora; é sabido que muitos alunos não possuem computador em casa e estas dificuldades no manuseio pode causar lentidão na aula e atraso do cronograma.

\subsection{Descrição geral}

Esta atividade prevê uma complementação da atual abordagem da Matemática Financeira proposta no ensino médio. Pretende-se sair da monotonia teórica presente na maioria das atividades, para uma explicação mais prática, com conceitos presentes no cotidiano do aluno e a utilização de planilha eletrônica e calculadora, instrumentos tão presentes e comuns a estes alunos nos dias atuais.

A atividade busca construir o conhecimento através de exemplos e situações práticas para depois apresentar as fórmulas. Sabe-se que isto não é possível em todos os tópicos, mas na maioria das atividades os exemplos, principalmente os que envolvam situações práticas, serão os norteadores das atividades de explicação e também do desenvolvimento de exercícios.

\subsection{Utilizando a calculadora e a planilha eletrônica}

No exemplo seguinte vamos aprender o passo a passo de como utilizar a calculadora do computador na resolução de um dos exemplos propostos no capítulo 2 .

Consideremos o exemplo 2.4.1, onde se faz necessário o seguinte cálculo para o valor da prestação no sistema de amortização SAC: 


$$
R=100000 \cdot \frac{0,140175}{\left[1-(1+0,140175)^{-10}\right]}
$$

Na figura 3.1 abaixo temos o modelo da calculadora científica encontrada nos computadores com sistema operacional Windows:

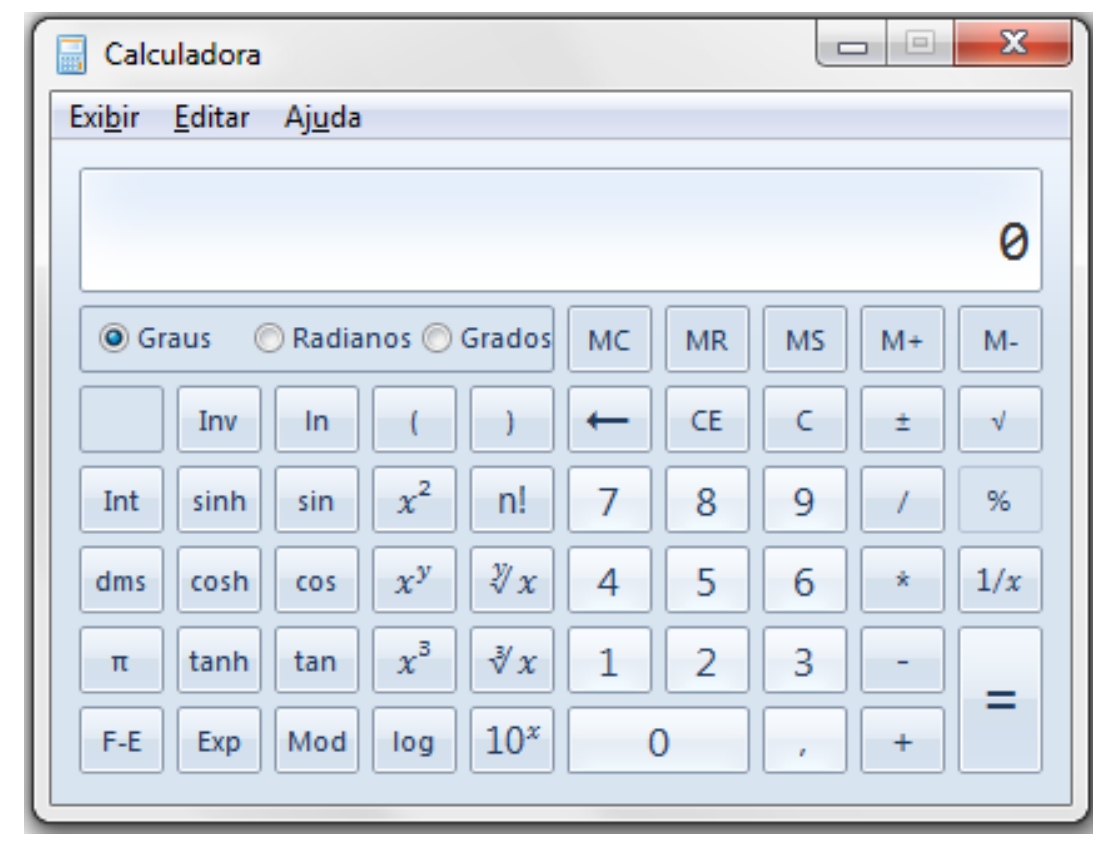

Figura 3.1: Modelo de calculadora presente nos computadores com sistema operacional Windows

Veremos agora como inserir os dados do problema, com a sequência a ser digitada na calculadora:

Insira o valor 100000:

Em seguida a tecla de multiplicação, representada pelo *:

Abrimos o parêntesis e inserimos o valor do numerador: (0,140175

Em seguida a tecla de divisão, representada pela /

Cabe salientar que na calculadora em questão não constam colchetes ou chaves, portanto orientar o aluno a usar o parêntesis. Podemos assim digitar o denominador: $(1-(1+0,140175)$

No caso a potenciação é representada pela seguinte tecla: $x^{y}$

Finalmente digitaremos - 10 entre parêntesis, fechando os demais parêntesis: $(-10))$ )

Após digitada a expressão surgirá no visor:

$\left.10000 *\left(0,140175 /\left(1-(1+0,140175)^{0-10}\right)\right)\right)$

Apertando a tecla igual: $=$

Temos o resultado do nosso cálculo: 19184,449212400015173098912655838

Por uma questão de praticidade e considerando que nossa moeda possui apenas duas casas decimais, que representam os centavos, utilizaremos os critérios de aproximação, adotando o valor 19184,45. 
Para o cálculo com utilização de planilha eletrônica é importante ressaltar que o cálculo deve sempre iniciar com sinal de igual $(=)$ e o sinal de potenciação é representado pelo acento circunflexo. Considerando o mesmo raciocínio da calculadora temos a seguinte expressão:

$\left.=10000 *\left(0,140175 /\left(1-(1+0,140175)^{-10}\right)\right)\right)$

Apertando a tecla "Enter", temos o resultado: 19184,45.

As atividades propostas abaixo serão corrigidas utilizando a codificação de planilhas eletrônicas.

\subsection{Atividade 1: Taxa de inflação e ganho real + Caderneta de Poupança}

No Brasil o tema inflação e, consequentemente, o ganho real são conceitos que não podem ser ignorados no ensino da matemática financeira e quando pensamos em aplicar recursos a opção mais tradicional e popular é a caderneta de poupança.

A proposta para a primeira atividade é a apresentação do item 2.2 aprofundando o assunto de acordo com a disponibilidade e o interesse dos alunos. A sugestão é que sejam resolvidos os exemplos 2.2.1, 2.2.2, 2.2.3, 2.2.5 e 2.2.7.

Nos exercícios seguintes, serão verificados os conceitos apresentados e algumas aplicações dos assuntos:

1) No primeiro mês de um ano a taxa de inflação foi de 1,27\%. No segundo mês, foi de $1,56 \%$, e no terceiro mês de $1,89 \%$. De quanto foi a inflação acumulada no trimestre?

Resposta: $4,79 \%$ a.t.

2) Determinar a variação real no poder aquisitivo de um assalariado que obtém, em determinado semestre, um reajuste salarial de $12 \%$, admitindo que a inflação do período tenha atingido: a) $8 \%$; b) $12 \%$; c) $20 \%$

Resposta: a) $3,7 \%$; b) $0 \%$; c) - $6,67 \%$

3) Um investidor adquiriu um título por $\mathrm{R} \$ 40000,00$ e o resgatou 30 dias após por $\mathrm{R} \$ 41997,00$. Sabendo que a inflação deste período atingiu 6,6\%, determine o ganho real mensal auferido pelo investidor.

Resposta: - 1,5\% a.m. 
4) Calcular a rentabilidade nominal anual de uma caderneta de poupança sendo 7,5\% a correção monetária (TR) do ano. (Considere a taxa Selic atual de 14,25\%)

Resposta: $14,13 \%$ a.a.

Correção dos exercícios:

1) Vimos que a inflação acumulada será calculada por:

$=((1+0,0127) \cdot(1+0,0156) \cdot(1+0,0189))-1$

O resultado obtido após digitar a tecla Enter é: 0,047936734. Isto é, aproximadamente, $4,79 \%$.

2) A variação real será dada pela expressão:

a) $=\frac{1+0,12}{1+0,08}-1$, resultando em um ganho real de, aproximadamente, $3,7 \%$.

b) $=\frac{1+0,12}{1+0,12}-1$, resultando em um ganho real de 0 .

c) $=\frac{1+0,12}{1+0,2}-1$, resultando em um ganho real negativo de, aproximadamente, $6,67 \%$, ou seja uma perda real.

3) Nesta questão é importante verificarmos inicialmente o ganho nominal da aplicação: $=\frac{41997}{40000}-1$, resultando em 0,049925 .

$\mathrm{Na}$ sequência, aplicar o mesmo raciocínio da questão anterior $=\frac{(1+0,049925)}{(1+0,066)}-1$, resultando em um ganho real negativo de, aproximadamente, $1,5 \%$.

4) Nesta questão iremos calcular primeiramente os juros da poupança no ano, que é de $0,5 \%$ a.m. Sendo assim, usando o conceito de juros compostos:

$=(1+0,005)^{12}$, resultando em 1,061677812.

Acumulando esse valor com a TR do ano, temos:

$=(1+0,005)^{1} 2 \cdot(1+0,075)$, resultando em 1,141303648 .

Subtraindo 1 temos um ganho nominal de, aproximadamente, 14,13\%

\subsection{Atividade 2: Valor atual de um conjunto de capitais}

A proposta para a segunda atividade é a explanação do item 2.3, resolvendo os exemplos 2.3.1, 2.3.2 e 2.3.3.

Seguem os exercícios propostos sobre o assunto: 
1) Quanto uma pessoa deve aplicar hoje, a juros compostos e à taxa de 1,4\% a.m., para poder pagar uma dívida de $\mathrm{R} \$ 3600,00$ daqui a 3 meses e outra de $\mathrm{R} \$ 8700,00$ daqui a 5 meses?

\section{Resposta: $\mathrm{R} \$ 11568,70$}

2) Uma televisão é vendida à vista por $\mathrm{R} \$ 900,00$ ou a prazo em 3 prestações mensais de $\mathrm{R} \$ 305,00$ cada uma. A primeira prestação vence um mês após a compra. Qual a melhor alternativa de pagamento para um comprador que aplica seu dinheiro a juros compostos, se a taxa for:
a) 1,5
b) 0,5

Resposta: a) a prazo; b) à vista

3) O preço à vista de um automóvel usado é $\mathrm{R} \$ 18000,00$, mas pode ser vendido a prazo com $20 \%$ de entrada mais 5 prestações mensais de $\mathrm{R} \$ 3000,00$ cada uma. Qual a melhor alternativa de pagamento para um comprador que aplica seu dinheiro a juros compostos à taxa de 1,6\% a.m.?

Resposta: Pagamento a prazo (O valor atual é $\mathrm{R} \$ 17906,04$, portanto inferior ao valor para pagamento à vista).

Correção dos exercícios:

1) No caso devemos trazer os dois pagamentos a valor presente:

Situação 1: $\mathrm{R} \$ 3600$ daqui a 3 meses à uma taxa de 1,4\% a.m:

$$
=\frac{3600}{(1+0,014)^{3}} \text {, resultando em } \mathrm{R} \$ 3452,94 \text {. }
$$

Situação 2: R $\$ 8700$ daqui a 5 meses à uma taxa de 1,4\% a.m: $=\frac{8700}{(1+0,014)^{5}}$, resultando em $\mathrm{R} \$ 8115,77$.

O resultado esperado é dado pela soma dos dois valores, ou seja, 11.568,70.

2) Neste caso temos que o valor à vista está em valor atual. Logo, devemos trazer à valor presente as três prestações do pagamento à prazo: 
a) Primeira prestação, após um mês: $=\frac{305}{(1+0,015)^{1}}$, resultando em $\mathrm{R} \$ 300,49$ Segunda prestação, após dois meses: $=\frac{305}{(1+0,015)^{2}}$, resultando em R $\$ 296,05$ Terceira prestação, após três meses: $=\frac{305}{(1+0,015)^{3}}$, resultando em $\mathrm{R} \$ 291,68$

Logo, à prazo é mais vantajoso pois seria necessário $\mathrm{R} \$ 888,22$ para efetuar o pagamento das três prestações, valor inferior aos $\mathrm{R} \$ 900,00$ à vista.

b) Primeira prestação, após um mês: $=\frac{305}{(1+0,005)^{1}}$, resultando em $\mathrm{R} \$ 303,48$ Segunda prestação, após dois meses: $=\frac{305}{(1+0,005)^{2}}$, resultando em $\mathrm{R} \$ 301,97$ Terceira prestação, após três meses: $=\frac{305}{(1+0,005)^{3}}$, resultando em $\mathrm{R} \$ 300,47$

Logo, neste caso é mais vantajoso pagar à vista, pois seu valor presente de $\mathrm{R} \$ 900,00$ é inferior ao valor presente à prazo, que é de $\mathrm{R} \$ 905,93$.

3) O raciocínio será análogo ao item anterior, lembrando que 3600 (20\% de 18000,00) que será pago à vista, já está no valor atual.

Trazendo as demais parcelas para o valor presente, temos:

Primeira prestação: $=\frac{3000}{(1+0,016)^{1}}$, resultando em $\mathrm{R} \$ 2952,76$

Segunda prestação: $=\frac{3000}{(1+0,016)^{2}}$, resultando em $\mathrm{R} \$ 2906,26$

Terceira prestação: $=\frac{3000}{(1+0,016)^{3}}$, resultando em $\mathrm{R} \$ 2860,49$

Quarta prestação: $=\frac{3000}{(1+0,016)^{4}}$, resultando em $\mathrm{R} \$ 2815,44$

Quinta prestação: $=\frac{3000}{(1+0,016)^{5}}$, resultando em $\mathrm{R} \$ 2771,10$

Portanto, somando as parcelas chegamos ao valor presente de $\mathrm{R} \$ 17906,04$, inferior aos $\mathrm{R} \$ 18000,00$ para pagamento à vista. Logo, é mais vantajoso pagar à prazo.

\subsection{Atividade 3: Sistemas de amortização}

Para a realização das atividades propomos, além da discussão abaixo, a explicação do item 2.4 com a resolução do exemplo 2.4.1 nos sistemas SAC e SAF, nas modalidades com e sem carência.

Os financiamentos imobiliários, que com os novos programas habitacionais do Governo Federal, ganharam grande impulso nos últimos anos, possuem como base os sistemas de amortização SAC ou SAF (PRICE), já vistos anteriormente, e tem juros reduzidos, mas é importante saber quanto juro e demais tarifas estão inclusas no valor final.

É importante fomentar a discussão em sala de aula sobre as possíveis formas de financiamento, prazos e taxas, para que o aluno possa tomar decisões sobre as situações 
apresentadas.

A Figura 3.2 apresenta uma simulação de financiamento de um imóvel no valor de $\mathrm{R} \$ 200000,00$, onde serão financiados R\$140000,00 no sistema de amortização SAC para pagamento em 240 parcelas à uma taxa efetiva de 8,3499\% a.a. + TR (taxa referencial), e também o valor da $1^{a}$ e última parcelas, respectivamente $\mathrm{R} \$ 1582,50$ e $\mathrm{R} \$ 472,42$, considerando o menor seguro, o CET (custo efetivo total) atinge 9,4409\%.

\begin{tabular}{|c|c|c|c|c|}
\hline \multicolumn{2}{|c|}{ Valor do imóvel } & \multicolumn{3}{|c|}{$\mathrm{R} \$ 200.000,00$} \\
\hline \multicolumn{2}{|c|}{ Prazo máximo } & \multicolumn{3}{|c|}{360 meses } \\
\hline \multicolumn{2}{|c|}{ Cota máxima financiamento } & \multicolumn{3}{|c|}{$80 \%$} \\
\hline \multicolumn{2}{|c|}{ Valor da entrada } & \multicolumn{3}{|c|}{$\mathrm{R} \$ 60.000,00 \quad$ Alterar } \\
\hline \multicolumn{2}{|c|}{ Prazo desejável } & \multicolumn{3}{|c|}{240 meses Alterar } \\
\hline \multicolumn{2}{|c|}{ Valor do financiamento } & \multicolumn{3}{|c|}{$\mathrm{R} \$ 140.000,00$} \\
\hline \multicolumn{2}{|c|}{ Sistema de amortização } & \multicolumn{3}{|c|}{ SAC Alterar } \\
\hline & $\begin{array}{l}\text { CAIXA } \\
\text { Seguradora } \\
\text { Clique para detalhar }\end{array}$ & $\begin{array}{l}\text { W TOKIOMARINe } \\
\text { Clique para detalhar }\end{array}$ & $\begin{array}{l}\text { PANseguros } \\
\text { Clique para detalhar }\end{array}$ & $\begin{array}{l}\text { CAIZA segurotar } \\
\text { seguradora somat } \\
\text { Clique para detalhar }\end{array}$ \\
\hline $\begin{array}{l}\text { Juros } \\
\text { Nominais } \\
\text { (taxas de juros } \\
\text { a.s. + TR) }\end{array}$ & & \multicolumn{2}{|c|}{$8.0465 \%$ a.a. $+T R \%$} & \\
\hline $\begin{array}{l}\text { Juros } \\
\text { Efetivos } \\
\text { (taxas de juros } \\
\text { a.s. }+ \text { TR) }\end{array}$ & & \multicolumn{2}{|c|}{$8.3499 \%$ a.a. + TR\% } & \\
\hline $\begin{array}{l}1^{\mathrm{a}} \\
\text { Prestação }\end{array}$ & $\begin{array}{c}\mathrm{R} \$ 1.595,34 \\
\text { Demais prestações }\end{array}$ & $\begin{array}{c}\mathrm{R} \$ 1.582,50 \\
\text { Demais prestações }\end{array}$ & $\begin{array}{c}\mathrm{R} \$ 1.584,16 \\
\text { Demais prestações }\end{array}$ & $\begin{array}{c}\mathrm{R} \$ 1.605,34 \\
\text { Demais prestações }\end{array}$ \\
\hline $\begin{array}{l}\text { Última } \\
\text { Prestação }\end{array}$ & $\mathrm{R} \$ 472,42$ & $\mathrm{R} \$ 472,42$ & $\mathrm{R} \$ 472,42$ & $\mathrm{R} \$ 472,42$ \\
\hline $\begin{array}{l}\text { CET (Cousto } \\
\text { Etotio Total } \\
\text { o.a.) }\end{array}$ & $9,5394 \%$ & $9,4409 \%$ & $9,4681 \%$ & $9,6661 \%$ \\
\hline
\end{tabular}

Figura 3.2: Financiamento de $\mathrm{R} \$ 140$ mil por 240 meses no SAC 
A Figura 3.3 apresenta a mesma simulação anterior usando a tabela PRICE:

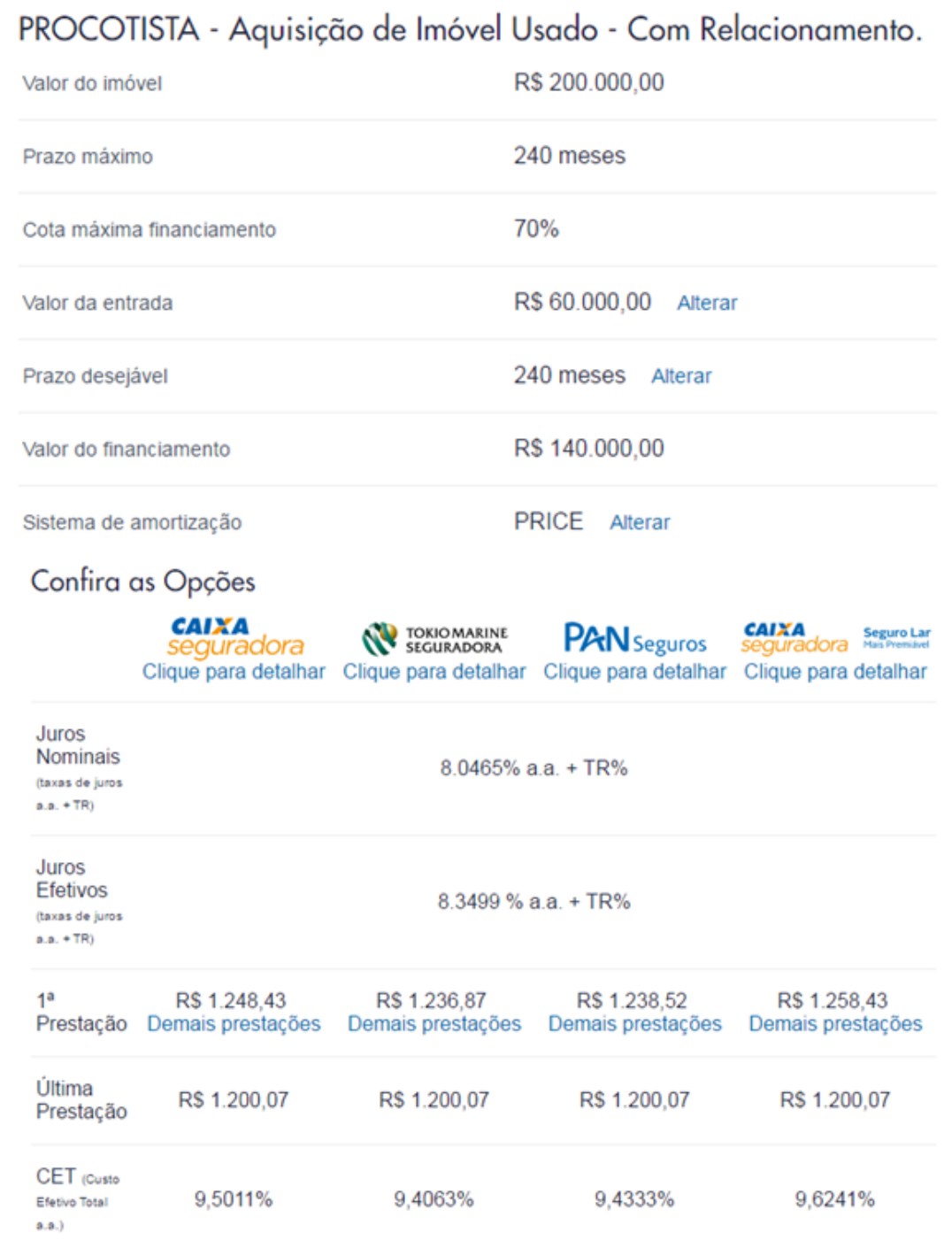

Figura 3.3: Financiamento de $\mathrm{R} \$ 140$ mil por 240 meses na tabela PRICE

No caso as prestações, que deveriam ser constantes, tem leve redução por conta da redução gradual do valor do seguro, atingindo CET (custo efetivo total) de 9,4063\% no melhor cenário.

Após a resolução dos exercícios é importante que o professor discuta com os alunos sobre o melhor sistema entre os dois propostos para o financiamento em questão, mostrando os prós e os contras de cada um deles.

Após apresentado esse cenário propomos os seguintes exercícios: (no caso, já que a tabela é grande parte da resposta já apresentamos a solução da questão)

1) Uma casa de $R \$ 35.000,00$ foi financiada a uma taxa de $2,75 \%$ ao mês, para ser paga em 10 anos. Calcule o saldo devedor após o $5^{\circ}$ mês no SAC e no SAF (PRICE). 
A tabela 3.1 abaixo apresenta a evolução do financiamento na tabela PRICE:

\begin{tabular}{|c|c|c|c|c|}
\hline $\begin{array}{c}\text { Períodos } \\
(\text { meses })\end{array}$ & $\begin{array}{c}\text { Saldo devedor } \\
(\mathrm{R} \$)\end{array}$ & $\begin{array}{c}\text { Amortização } \\
(\mathrm{R} \$)\end{array}$ & $\begin{array}{c}\text { Juros } \\
(\mathrm{R} \$)\end{array}$ & $\begin{array}{c}\text { Prestação } \\
(\mathrm{R} \$)\end{array}$ \\
\hline 0 & $\mathrm{R} \$ 35.000,00$ & & & \\
\hline 1 & $\mathrm{R} \$ 34.961,39$ & $\mathrm{R} \$ 38,61$ & $\mathrm{R} \$ 962,50$ & $\mathrm{R} \$ 1.001,11$ \\
\hline 2 & $\mathrm{R} \$ 34.921,73$ & $\mathrm{R} \$ 39,67$ & $\mathrm{R} \$ 961,44$ & $\mathrm{R} \$ 1.001,11$ \\
\hline 3 & $\mathrm{R} \$ 34.880,97$ & $\mathrm{R} \$ 40,76$ & $\mathrm{R} \$ 960,35$ & $\mathrm{R} \$ 1.001,11$ \\
\hline 4 & $\mathrm{R} \$ 34.839,09$ & $\mathrm{R} \$ 41,88$ & $\mathrm{R} \$ 959,23$ & $\mathrm{R} \$ 1.001,11$ \\
\hline 5 & $\mathrm{R} \$ 34.796,05$ & $\mathrm{R} \$ 43,03$ & $\mathrm{R} \$ 958,07$ & $\mathrm{R} \$ 1.001,11$ \\
\hline
\end{tabular}

Tabela 3.1: Exercício 1 resolvido pela tabela PRICE

A tabela 3.2 abaixo apresenta a evolução do financiamento no sistema SAC:

\begin{tabular}{|c|c|c|c|c|}
\hline $\begin{array}{c}\text { Períodos } \\
(\text { meses })\end{array}$ & $\begin{array}{c}\text { Saldo devedor } \\
(\mathrm{R} \$)\end{array}$ & $\begin{array}{c}\text { Amortização } \\
(\mathrm{R} \$)\end{array}$ & $\begin{array}{c}\text { Juros } \\
(\mathrm{R} \$)\end{array}$ & $\begin{array}{c}\text { Prestação } \\
(\mathrm{R} \$)\end{array}$ \\
\hline 0 & $\mathrm{R} \$ 35.000,00$ & & & \\
\hline 1 & $\mathrm{R} \$ 34.708,33$ & $\mathrm{R} \$ 291,67$ & $\mathrm{R} \$ 962,50$ & $\mathrm{R} \$ 1.254,17$ \\
\hline 2 & $\mathrm{R} \$ 34.416,67$ & $\mathrm{R} \$ 291,67$ & $\mathrm{R} \$ 954,48$ & $\mathrm{R} \$ 1.246,15$ \\
\hline 3 & $\mathrm{R} \$ 34.125,00$ & $\mathrm{R} \$ 291,67$ & $\mathrm{R} \$ 946,46$ & $\mathrm{R} \$ 1.238,13$ \\
\hline 4 & $\mathrm{R} \$ 33.833,33$ & $\mathrm{R} \$ 291,67$ & $\mathrm{R} \$ 938,44$ & $\mathrm{R} \$ 1.230,10$ \\
\hline 5 & $\mathrm{R} \$ 33.541,67$ & $\mathrm{R} \$ 291,67$ & $\mathrm{R} \$ 930,42$ & $\mathrm{R} \$ 1.222,08$ \\
\hline
\end{tabular}

Tabela 3.2: Exercício 1 resolvido pelo sistema SAC

2) Considere um empréstimo de $R \$ 50.000,00$, a ser pago em 6 meses, a uma taxa de juros de 26,8242\% ao ano. Faça o financiamento através da Tabela Price e SAC.

A tabela 3.3 abaixo apresenta a evolução do financiamento na tabela PRICE:

\begin{tabular}{|c|c|c|c|c|}
\hline $\begin{array}{c}\text { Períodos } \\
(\text { meses })\end{array}$ & $\begin{array}{c}\text { Saldo devedor } \\
(\mathrm{R} \$)\end{array}$ & $\begin{array}{c}\text { Amortização } \\
(\mathrm{R} \$)\end{array}$ & $\begin{array}{c}\text { Juros } \\
(\mathrm{R} \$)\end{array}$ & $\begin{array}{c}\text { Prestação } \\
(\mathrm{R} \$)\end{array}$ \\
\hline 0 & $\mathrm{R} \$ 50.000,00$ & & & \\
\hline 1 & $\mathrm{R} \$ 42.073,71$ & $\mathrm{R} \$ 7.926,29$ & $\mathrm{R} \$ 1.000,00$ & $\mathrm{R} \$ 8.926,29$ \\
\hline 2 & $\mathrm{R} \$ 33.988,89$ & $\mathrm{R} \$ 8.084,82$ & $\mathrm{R} \$ 841,47$ & $\mathrm{R} \$ 8.926,29$ \\
\hline 3 & $\mathrm{R} \$ 25.742,38$ & $\mathrm{R} \$ 8.246,51$ & $\mathrm{R} \$ 679,78$ & $\mathrm{R} \$ 8.926,29$ \\
\hline 4 & $\mathrm{R} \$ 17.330,94$ & $\mathrm{R} \$ 8.411,44$ & $\mathrm{R} \$ 514,85$ & $\mathrm{R} \$ 8.926,29$ \\
\hline 5 & $\mathrm{R} \$ 8.751,27$ & $\mathrm{R} \$ 8.579,67$ & $\mathrm{R} \$ 346,62$ & $\mathrm{R} \$ 8.926,29$ \\
\hline 6 & $\mathrm{R} \$ 0,00$ & $\mathrm{R} \$ 8.751,27$ & $\mathrm{R} \$ 175,03$ & $\mathrm{R} \$ 8.926,29$ \\
\hline
\end{tabular}

Tabela 3.3: Exercício 2 resolvido pela tabela PRICE 
A tabela 3.4 abaixo apresenta a evolução do financiamento no sistema SAC:

\begin{tabular}{|c|c|c|c|c|}
\hline $\begin{array}{c}\text { Períodos } \\
(\text { meses })\end{array}$ & $\begin{array}{c}\text { Saldo devedor } \\
(\mathrm{R} \$)\end{array}$ & $\begin{array}{c}\text { Amortização } \\
(\mathrm{R} \$)\end{array}$ & $\begin{array}{c}\text { Juros } \\
(\mathrm{R} \$)\end{array}$ & $\begin{array}{c}\text { Prestação } \\
(\mathrm{R} \$)\end{array}$ \\
\hline 0 & $\mathrm{R} \$ 50.000,00$ & & & \\
\hline 1 & $\mathrm{R} \$ 41.666,67$ & $\mathrm{R} \$ 8.333,33$ & $\mathrm{R} \$ 1.000,00$ & $\mathrm{R} \$ 9.333,33$ \\
\hline 2 & $\mathrm{R} \$ 33.333,33$ & $\mathrm{R} \$ 8.333,33$ & $\mathrm{R} \$ 833,33$ & $\mathrm{R} \$ 9.166,67$ \\
\hline 3 & $\mathrm{R} \$ 25.000,00$ & $\mathrm{R} \$ 8.333,33$ & $\mathrm{R} \$ 666,67$ & $\mathrm{R} \$ 9.000,00$ \\
\hline 4 & $\mathrm{R} \$ 16.666,67$ & $\mathrm{R} \$ 8.333,33$ & $\mathrm{R} \$ 500,00$ & $\mathrm{R} \$ 8.833,33$ \\
\hline 5 & $\mathrm{R} \$ 8.333,33$ & $\mathrm{R} \$ 8.333,33$ & $\mathrm{R} \$ 333,33$ & $\mathrm{R} \$ 8.666,67$ \\
\hline 6 & $\mathrm{R} \$ 0,00$ & $\mathrm{R} \$ 8.333,33$ & $\mathrm{R} \$ 166,67$ & $\mathrm{R} \$ 8.500,00$ \\
\hline
\end{tabular}

Tabela 3.4: Exercício 2 resolvido pelo sistema SAC

3) Joaquim decidiu comprar um carro em uma concessionária. A atendente lhe ofereceu um plano de pagamento parcelado, em que a taxa mensal de juros cobrada era de 3,5\% ao mês, em doze parcelas iguais de $\mathrm{R} \$ 3.311,49$. Joaquim ofereceu uma contra proposta. Daria $20 \%$ do valor do carro como entrada, e pagaria o restante em 10 parcelas iguais, mas com uma redução da taxa de juros para o nível de $3 \%$ ao mês. Dado que a concessionária aceitou o negócio proposto por Joaquim, construa a Tabela Price desse financiamento.

Primeiramente é importante trazer o valor do carro à valor presente, que será de $\mathrm{R} \$ 32000,00$.

A proposta de Joaquim consiste em dar uma entrada de $\mathrm{R} \$ 6400,00$ e financiar os $\mathrm{R} \$ 25600$ restantes em 10 parcelas, com taxa de $3 \%$ a.m. Diante disso, temos o seguinte cenário apresentado na tabela 3.5:

\begin{tabular}{|c|c|c|c|c|}
\hline $\begin{array}{c}\text { Períodos } \\
(\text { meses })\end{array}$ & $\begin{array}{c}\text { Saldo devedor } \\
(\mathrm{R} \$)\end{array}$ & $\begin{array}{c}\text { Amortização } \\
(\mathrm{R} \$)\end{array}$ & $\begin{array}{c}\text { Juros } \\
(\mathrm{R} \$)\end{array}$ & $\begin{array}{c}\text { Prestação } \\
(\mathrm{R} \$)\end{array}$ \\
\hline 0 & $\mathrm{R} \$ 25.600,00$ & & & \\
\hline 1 & $\mathrm{R} \$ 23.366,90$ & $\mathrm{R} \$ 2.233,10$ & $\mathrm{R} \$ 768,00$ & $\mathrm{R} \$ 3.001,10$ \\
\hline 2 & $\mathrm{R} \$ 21.066,81$ & $\mathrm{R} \$ 2.300,09$ & $\mathrm{R} \$ 701,01$ & $\mathrm{R} \$ 3.001,10$ \\
\hline 3 & $\mathrm{R} \$ 18.697,71$ & $\mathrm{R} \$ 2.369,10$ & $\mathrm{R} \$ 632,00$ & $\mathrm{R} \$ 3.001,10$ \\
\hline 4 & $\mathrm{R} \$ 16.257,54$ & $\mathrm{R} \$ 2.440,17$ & $\mathrm{R} \$ 560,93$ & $\mathrm{R} \$ 3.001,10$ \\
\hline 5 & $\mathrm{R} \$ 13.744,16$ & $\mathrm{R} \$ 2.513,37$ & $\mathrm{R} \$ 487,73$ & $\mathrm{R} \$ 3.001,10$ \\
\hline 6 & $\mathrm{R} \$ 11.155,39$ & $\mathrm{R} \$ 2.588,78$ & $\mathrm{R} \$ 412,32$ & $\mathrm{R} \$ 3.001,10$ \\
\hline 7 & $\mathrm{R} \$ 8.488,95$ & $\mathrm{R} \$ 2.666,44$ & $\mathrm{R} \$ 334,66$ & $\mathrm{R} \$ 3.001,10$ \\
\hline 8 & $\mathrm{R} \$ 5.742,52$ & $\mathrm{R} \$ 2.746,43$ & $\mathrm{R} \$ 254,67$ & $\mathrm{R} \$ 3.001,10$ \\
\hline 9 & $\mathrm{R} \$ 2.913,69$ & $\mathrm{R} \$ 2.828,83$ & $\mathrm{R} \$ 172,28$ & $\mathrm{R} \$ 3.001,10$ \\
\hline 10 & $\mathrm{R} \$ 0,00$ & $\mathrm{R} \$ 2.913,69$ & $\mathrm{R} \$ 87,41$ & $\mathrm{R} \$ 3.001,10$ \\
\hline
\end{tabular}

Tabela 3.5: Exercício 3 resolvido pela tabela PRICE

4) Uma empresa fez um financiamento de $\mathrm{R} \$ 110.000,00$. A taxa de juros foi de $2 \%$ 
ao mês. O pagamento será feito em 24 parcelas. Com base nestes dados, calcule:

a) No SAC, qual seria o valor do terceiro pagamento feito?

Considerando o $\mathrm{SAC}$ temos o cenário até o terceiro pagamento apresentado na tabela 3.6:

\begin{tabular}{|c|c|c|c|c|}
\hline $\begin{array}{c}\text { Períodos } \\
(\text { meses })\end{array}$ & $\begin{array}{c}\text { Saldo devedor } \\
(\mathrm{R} \$)\end{array}$ & $\begin{array}{c}\text { Amortização } \\
(\mathrm{R} \$)\end{array}$ & $\begin{array}{c}\text { Juros } \\
(\mathrm{R} \$)\end{array}$ & $\begin{array}{c}\text { Prestação } \\
(\mathrm{R} \$)\end{array}$ \\
\hline 0 & $\mathrm{R} \$ 110.000,00$ & & & \\
\hline 1 & $\mathrm{R} \$ 105.416,67$ & $\mathrm{R} \$ 4.583,33$ & $\mathrm{R} \$ 2.200,00$ & $\mathrm{R} \$ 6.783,33$ \\
\hline 2 & $\mathrm{R} \$ 100.833,33$ & $\mathrm{R} \$ 4.583,33$ & $\mathrm{R} \$ 2.108,33$ & $\mathrm{R} \$ 6.691,67$ \\
\hline 3 & $\mathrm{R} \$ 96.250,00$ & $\mathrm{R} \$ 4.583,33$ & $\mathrm{R} \$ 2.016,67$ & $\mathrm{R} \$ 6.600,00$ \\
\hline
\end{tabular}

Tabela 3.6: Exercício 4a)

Portanto, o valor da $3^{\text {a }}$ prestação é $\mathrm{R} \$ 6.600,00$.

b) No Price, qual seria o valor do saldo devedor após o terceiro pagamento feito?

Considerando a tabela PRICE temos o cenário até o terceiro pagamento apresentado na tabela 3.7:

\begin{tabular}{|c|c|c|c|c|}
\hline $\begin{array}{c}\text { Períodos } \\
(\text { meses })\end{array}$ & $\begin{array}{c}\text { Saldo devedor } \\
(\mathrm{R} \$)\end{array}$ & $\begin{array}{c}\text { Amortização } \\
(\mathrm{R} \$)\end{array}$ & $\begin{array}{c}\text { Juros } \\
(\mathrm{R} \$)\end{array}$ & $\begin{array}{c}\text { Prestação } \\
(\mathrm{R} \$)\end{array}$ \\
\hline 0 & $\mathrm{R} \$ 110.000,00$ & & & \\
\hline 1 & $\mathrm{R} \$ 106.384,18$ & $\mathrm{R} \$ 3.615,82$ & $\mathrm{R} \$ 2.200,00$ & $\mathrm{R} \$ 5.815,83$ \\
\hline 2 & $\mathrm{R} \$ 102.696,04$ & $\mathrm{R} \$ 3.688,14$ & $\mathrm{R} \$ 2.127,68$ & $\mathrm{R} \$ 5.815,81$ \\
\hline 3 & $\mathrm{R} \$ 98.934,14$ & $\mathrm{R} \$ 3.761,90$ & $\mathrm{R} \$ 2.053,92$ & $\mathrm{R} \$ 5.815,82$ \\
\hline
\end{tabular}

Tabela 3.7: Exercício 4b)

Portanto, o saldo devedor ao final do $3^{\circ}$ pagamento é $\mathrm{R} \$ 98934,14$.

c) Após o terceiro pagamento feito, quantos \% o saldo devedor do sistema Price é maior que do SAC?

Para o cálculo em questão temos $=\frac{98934,14}{96250,00}-1=2,79 \%$.

5) Um indivíduo fez um financiamento pelo prazo de 2,5 anos, taxa de $2 \%$ ao mês e valor de $\mathrm{R} \$ 50.000,00$. Após fazer o terceiro pagamento, fez um aporte adicional de $\mathrm{R} \$ 10.000,00$ para amortizar o saldo devedor. Foi feito o recálculo do valor das parcelas de forma a continuar com o mesmo prazo. Dado que no quinto mês decidiu pagar toda sua dívida de uma só vez, qual foi esse valor pago? Faça o cálculo tanto para Tabela Price como para o SAC.

A tabela 3.8 seguinte apresenta o cenário do exercício 5 utilizando a tabela PRICE: 


\begin{tabular}{|c|c|c|c|c|}
\hline $\begin{array}{c}\text { Períodos } \\
(\text { meses })\end{array}$ & $\begin{array}{c}\text { Saldo devedor } \\
(\mathrm{R} \$)\end{array}$ & $\begin{array}{c}\text { Amortização } \\
(\mathrm{R} \$)\end{array}$ & $\begin{array}{c}\text { Juros } \\
(\mathrm{R} \$)\end{array}$ & $\begin{array}{c}\text { Prestação } \\
(\mathrm{R} \$)\end{array}$ \\
\hline 0 & $\mathrm{R} \$ 50.000,00$ & & & \\
\hline 1 & $\mathrm{R} \$ 48.767,50$ & $\mathrm{R} \$ 1.232,50$ & $\mathrm{R} \$ 1.000,00$ & $\mathrm{R} \$ 2.232,50$ \\
\hline 2 & $\mathrm{R} \$ 47.510,36$ & $\mathrm{R} \$ 1.257,15$ & $\mathrm{R} \$ 975,35$ & $\mathrm{R} \$ 2.232,50$ \\
\hline 3 & $\mathrm{R} \$ 36.228,07$ & $\mathrm{R} \$ 11.282,29$ & $\mathrm{R} \$ 950,21$ & $\mathrm{R} \$ 12.232,50$ \\
\hline 4 & $\mathrm{R} \$ 35.203,07$ & $\mathrm{R} \$ 1.025,00$ & $\mathrm{R} \$ 724,56$ & $\mathrm{R} \$ 1.749,57$ \\
\hline 5 & $\mathrm{R} \$ 34.157,56$ & $\mathrm{R} \$ 1.045,50$ & $\mathrm{R} \$ 704,06$ & $\mathrm{R} \$ 1.749,57$ \\
\hline
\end{tabular}

Tabela 3.8: Exercício 5 usando a tabela PRICE

Portanto, utilizando a Tabela PRICE o valor pago para a quitação do financiamento foi de $\mathrm{R} \$ 34157,56$.

Enquanto na tabela 3.9 apresentamos a situação usando o sistema SAC:

\begin{tabular}{|c|c|c|c|c|}
\hline $\begin{array}{c}\text { Períodos } \\
(\text { meses })\end{array}$ & $\begin{array}{c}\text { Saldo devedor } \\
(\mathrm{R} \$)\end{array}$ & $\begin{array}{c}\text { Amortização } \\
(\mathrm{R} \$)\end{array}$ & $\begin{array}{c}\text { Juros } \\
(\mathrm{R} \$)\end{array}$ & $\begin{array}{c}\text { Prestação } \\
(\mathrm{R} \$)\end{array}$ \\
\hline 0 & $\mathrm{R} \$ 50.000,00$ & & & \\
\hline 1 & $\mathrm{R} \$ 48.333,33$ & $\mathrm{R} \$ 1.666,67$ & $\mathrm{R} \$ 1.000,00$ & $\mathrm{R} \$ 2.666,67$ \\
\hline 2 & $\mathrm{R} \$ 46.666,67$ & $\mathrm{R} \$ 1.666,67$ & $\mathrm{R} \$ 966,67$ & $\mathrm{R} \$ 2.633,33$ \\
\hline 3 & $\mathrm{R} \$ 35.000,00$ & $\mathrm{R} \$ 11.666,67$ & $\mathrm{R} \$ 933,33$ & $\mathrm{R} \$ 12.600,00$ \\
\hline 4 & $\mathrm{R} \$ 33.703,70$ & $\mathrm{R} \$ 1.296,30$ & $\mathrm{R} \$ 700,00$ & $\mathrm{R} \$ 1.996,30$ \\
\hline 5 & $\mathrm{R} \$ 32.407,41$ & $\mathrm{R} \$ 1.296,30$ & $\mathrm{R} \$ 674,07$ & $\mathrm{R} \$ 1.970,37$ \\
\hline
\end{tabular}

Tabela 3.9: Exercício 5 usando o sistema SAC

Portanto, no sistema SAC o valor pago para a quitação do financiamento foi de $\mathrm{R} \$$ 32407,41 .

\subsection{Atividade 4: Montante de uma sequência uni- forme de depósitos}

Para a realização da atividade 4 sugerimos a explanação do item 2.5 e a resolução dos exemplos 2.5.1 e 2.5.2

1) Uma pessoa deposita mensalmente $R \$ 700,00$ num fundo de investimento que rende juros compostos, à taxa de 1,3\% a.m.. São feitos 25 depósitos.

a) Qual será seu montante no instante após o último depósito?

b) Qual será seu montante 3 meses após ter feito o último depósito?

Respostas: a) $\mathrm{R} \$ 20522,65$; b) $\mathrm{R} \$ 21333,49$ 
2) Quanto uma pessoa deverá depositar num fundo de investimento que rende à taxa de 1,2\% a.m., para ter um montante de $\mathrm{R} \$ 30000,00$ no instante após o último depósito? (Considere que foram feitos 40 depósitos)

Resposta: $\mathrm{R} \$ 588,75$.

3) Uma transportadora pretende comprar um caminhão dentro de 24 meses e estima que seu preço nesta data será $\mathrm{R} \$ 90000,00$. Para atingir seu objetivo ela resolve fazer 24 depósitos mensais de $\mathrm{x}$ reais cada um num fundo de investimentos que rende 1,5\% a.m, de modo que no instante do último depósito o saldo dessas aplicações seja $\mathrm{R} \$ 90000,00$.

a) Qual o valor de $x$ ?

b) No dia em que foi feito o $18^{\circ}$ depósito, surgiu uma emergência e a empresa teve que sacar todo o saldo das aplicações. Qual era o valor desse saldo?

Respostas: a) $\mathrm{R} \$ 3143,17$; b) $\mathrm{R} \$ 64401,59$

Correção dos exercícios:

1)

a) Sabemos que $M=R \cdot \frac{(1+i)^{n}-1}{i}$. No caso, $\mathrm{R}=700,00, \mathrm{n}=25$ e $\mathrm{i}=0,013$.

Logo $M=700 \cdot \frac{(1+0,013)^{25}-1}{0,013}=20522,65$

Portanto ao final dos 25 meses teremos um montante de $\mathrm{R} \$ 20522,65$.

b) O montante após 3 meses do último depósito será dado pelo conceito de juros compostos: $M=R \cdot(1+i)^{n}$. No caso $\mathrm{R}=20522,65, \mathrm{n}=3$ e $\mathrm{i}=0,013$.

Logo $M=20522,65 \cdot(1+0,013)^{3}=21333,49$

Portanto, o montante será de $\mathrm{R} \$ 21333,49$.

2) No caso, queremos $R$, sabendo que $M=30000, n=40$ e $\mathrm{i}=0,012$.

Logo $30000=R \cdot \frac{(1+0,012)^{40}-1}{0,012}$. Então $R=\frac{30000}{50,9553}=588,75$.

Portanto, para acumular $\mathrm{R} \$ 30000$ ao final de 40 prestações a uma taxa de 1,2\% ao mês é necessário realizar depósitos mensais de $\mathrm{R} \$ 588,75$.

3)

a) O item a é análogo ao anterior. $\operatorname{Logo} 90000=R \cdot \frac{(1+0,015)^{24}-1}{0,015}$.

Portanto $\mathrm{R}=\mathrm{R} \$ 3143,17$.

b) Aplicando a fórmula do montante, temos que $M=3413,17 \cdot \frac{(1+0,015)^{18}-1}{0,015}=64401,59$.

Portanto a empresa sacou $\mathrm{R} \$ 64401,59$ ao final do $18^{\circ}$ depósito. 


\subsection{Atividade 5: Questões sobre o assunto aplica- das no ENEM}

1) (ENEM 2011) - Considere que uma pessoa decida investir uma determinada quantia e que lhe sejam apresentadas três possibilidades de investimento, com rentabilidades líquidas garantidas pelo período de um ano, conforme descritas:

Investimento A: $3 \%$ ao mês;

Investimento B: $36 \%$ ao ano;

Investimento C: $18 \%$ ao semestre.

As rentabilidades, para esses investimentos, incidem sobre o valor do período anterior. O quadro fornece algumas aproximações para a análise das rentabilidades:

\begin{tabular}{|c|c|}
\hline $\mathrm{n}$ & $1,03^{n}$ \\
\hline 3 & 1,093 \\
\hline 6 & 1,194 \\
\hline 9 & 1,305 \\
\hline 12 & 1,426 \\
\hline
\end{tabular}

Tabela 3.10: Questão ENEM 2011

Para escolher o investimento com a maior rentabilidade anual, essa pessoa deverá

a) escolher qualquer um dos investimentos $\mathrm{A}, \mathrm{B}$ ou $\mathrm{C}$, pois as suas rentabilidades anuais são iguais a $36 \%$.

b) escolher os investimentos $\mathrm{A}$ ou $\mathrm{C}$, pois suas rentabilidades anuais são iguais a $39 \%$.

c) escolher o investimento $\mathrm{A}$, pois a sua rentabilidade anual é maior que as rentabilidades anuais dos investimentos $\mathrm{B}$ e $\mathrm{C}$.

d) escolher o investimento B, pois sua rentabilidade de $36 \%$ é maior que as rentabilidades de $3 \%$ do investimento A e de $18 \%$ do investimento $\mathrm{C}$.

e) escolher o investimento $\mathrm{C}$, pois sua rentabilidade de $39 \%$ ao ano é maior que a rentabilidade de $36 \%$ ao ano dos investimentos A e B.

Resposta: Alternativa C.

Para escolhermos a alternativa correta precisamos comparar os três investimentos dentro de um mesmo período. O mais indicado seria 2 anos.

Investimento A: $3 \%$ ao mês

1 ano $=12$ meses;

Rendimento $=(1+0,03)^{12}-1=1,03^{12}-1=1,426-1=0,426$.

Logo no investimento A teremos uma rentabilidade de $42,6 \%$ ao ano.

Investimento B: $36 \%$ ao ano. 
Investimento C: $18 \%$ ao semestre:

1 ano $=2$ semestres.

Rendimento $=(1+0,18)^{2}-1=1,18^{2}-1=1,3924-1=0,3924$.

Logo no investimento C teremos uma rentabilidade de $39,24 \%$ ao ano.

Portanto o investimento mais rentável é o A. Logo, a alternativa correta é a C.

2) (ENEM 2012) - Arthur deseja comprar um terreno de Cléber, que lhe oferece as seguintes possibilidades de pagamento:

- Opção 1: Pagar à vista, por $\mathrm{R} \$ 55$ 000,00;

- Opção 2: Pagar a prazo, dando uma entrada de $\mathrm{R} \$ 30$ 000,00, e mais uma prestação de $\mathrm{R} \$ 26000,00$ para dali a 6 meses;

- Opção 3: Pagar a prazo, dando uma entrada de $R \$ 20$ 000,00, mais uma prestação de $\mathrm{R} \$ 20$ 000,00, para dali a 6 meses e outra de $\mathrm{R} \$ 18$ 000,00 para dali a 12 meses da data da compra;

- Opção 4: Pagar a prazo dando uma entrada de $\mathrm{R} \$ 15$ 000,00 e o restante em 1 ano da data da compra, pagando $\mathrm{R} \$ 39$ 000,00;

- Opção 5: pagar a prazo, dali a um ano, o valor de $\mathrm{R} \$ 60$ 000,00.

Arthur tem o dinheiro para pagar à vista, mas avalia se não seria melhor aplicar o dinheiro do valor à vista (ou até um valor menor) em um investimento, com rentabilidade de $10 \%$ ao semestre, resgatando os valores à medida que as prestações da opção escolhida fossem vencendo.

Após avaliar a situação do ponto de vista financeiro e das condições apresentadas, Arthur concluiu que era mais vantajoso financeiramente escolher a opção
a) 1 .
b) 2 .
c) 3 .
d) 4 .
e) 5 .

Analisando cada um dos casos, temos:

opção 1: sem rendimento

opção 2:

entrada: 30000 
aplicação: $55000-30000=25000$

rendimento: $25000 \cdot 1,1=27500$

após a última prestação: 27500-26000=1500 (sobra)

opção 3:

entrada: 2000

aplicação: $55000-20000=35000$

rendimento: $35000 \cdot 1,1=38500$

após o pagamento da primeira prestação: 38500-20000=18500 (sobra)

nova aplicação: 18500

rendimento da nova aplicação: $18500 \cdot 1,1=20350$

após a última prestação: 20350-18000=2350 (sobra)

opção 4:

entrada: 15000

aplicação: $55000-15000=40000$

rendimento: $40000 \cdot 1,1=48400$

após pagamento da prestação: 48400-39000=9400 (sobra)

opção 5:

aplicação: 55000

rendimento: $55000 \cdot(1,1)^{2}=66550$

após pagamento da prestação: 66550-60000=6550 (sobra)

Com isso Arthur concluirá que o mais vantajoso financeiramente é a opção 4. 


\section{Capítulo 4}

\section{Considerações Finais}

O estudo da matemática financeira aliado à educação financeira deve ocupar um lugar de destaque no ensino médio, devido a sua grande aplicabilidade no cotidiano das pessoas, onde os acontecimentos financeiros são os mais diversos, indo de uma simples compra em um mercadinho do bairro a grandes financiamentos. Saber o que ocorre no mundo financeiro tornou-se uma necessidade.

Analisando as obras adotadas por diversas escolas de ensino médio foi percebido um déficit entre o que é proposto e o que efetivamente ocorre no cotidiano das pessoas.

O trabalho é uma incursão no terreno da matemática para ajudar o aluno a compreender melhor a lógica que leva a cálculos que são fundamentais para o seu dia-a-dia: por exemplo: que esquema de pagamento é melhor para a realidade de uma pessoa entre duas modalidades de financiamento para a aquisição da casa própria ou quanto alguém deve acumular para viver com uma renda de $\mathrm{R} \$ 5$ mil por mês a partir dos 60 anos.

Procuramos mostrar que a matemática que explica tais cálculos pode não ser tão complicada e que com algum esforço o aluno pode, se estiver disposto a se deter passo a passo no raciocínio exposto, tornar-se capacitado a: acompanhar as equações, entender a lógica e conseguir deduzir algumas fórmulas com conceitos já trabalhados e ainda estar em condições de fazer por si mesmo os cálculos.

Este trabalho, porém, não foi apenas sobre isso. Tínhamos o objetivo mais abrangente: colaborar na educação financeira dos alunos, enraizando valores nas pessoas, como: prudência, planejamento e preparação para o futuro.

O ser humano é, por sua natureza, imediatista. Aquele que for próximo da indiferença entre consumir hoje ou deixar para amanhã não irá cobrar muito para emprestar temporariamente seus recursos. Já aquele para quem for muito importante se saciar no presente irá provavelmente exigir uma compensação maior para ter de esperar para satisfazer suas intenções apenas no futuro.

Se a preferência pelo consumo imediato se manifesta em relação a pequenos atos, ela 
é bem mais marcante quando o benefício de espera é mais longo. Poupar durante cinco anos para poder dar entrada no preço de um imóvel sem ter certeza de assumir um endividamento excessivamente oneroso não é um hábito da maioria das pessoas. Que dirá, então, ter a disciplina de, voluntariamente, resistir durante 35 anos às tentações do dia a dia para, religiosamente, depositar $\mathrm{R} \$ 500$ ou $\mathrm{R} \$ 1$ mil para constituir uma reserva matemática para quando chegar o momento da aposentadoria não ter que depender exclusivamente do INSS.

A escola deveria fornecer ao futuro cidadão a base para que ele se prepare para enfrentar essas questões, em outras palavras, para prepara-lo para a vida. Infelizmente, não o faz. O resultado é que o adolescente de 16 anos aprende hoje uma série de disciplinas ligadas à sua formação humanística, que são importantes, mas para as quais provavelmente ele não tem amadurecimento suficiente para absorver devidamente, deixando de ser alertado para a importância de decisões financeiras que terá de tomar ao longo de sua vida adulta. As consequências aparecem anos mais tarde, ao "entrar no cheque especial" pagando juros elevados (algo que noções básicas de prudência financeira recomendariam evitar), na dificuldade de se planejar ao longo dos anos para não ter de viver sempre de aluguel ou na atitude de "depois a gente vê" quando se trata de começar a contribuir para uma previdência privada. Quando o indivíduo toma ciência do que isso implica, muitas vezes já é tarde: o dinheiro que deveria ter sido poupado para dar entrada em um apartamento foi "torrado" despreocupadamente nos primeiros anos de casamento e as pessoas "caem para trás" quando são informadas da joia que devem ter aos 45 anos para terem direito a uma renda complementar de $\mathrm{X}$ a partir dos 60 anos depois de terem passado 25 anos sem contribuir porque "depois a gente vê".

Ter consciência de que, a não ser que se tenha a sorte de ter nascido em "berço de ouro" ou de ganhar na loteria, o patrimônio acumulado por um indivíduo resulta da soma de pequenos atos de sacrifício financeiro feitos ao longo de anos não é algo que se alcance num estalar de dedos. Não é fruto de um sermão nem algo que se atinja ouvindo alguém uma vez. É fruto de uma reflexão interna que toma seu tempo.

Enfim, o que quisemos passar foi a mensagem de que bem-estar financeiro depende de uma multiplicidade de pequenos atos tomados, ou não, ao longo de anos. Tanto ou mais do que a explicação para as fórmulas aqui expostas, essa é a principal lição que gostaríamos que tivesse sido absorvida. 


\section{Referências Bibliográficas}

[1] ASSAF, Alexandre. MATEMÁtiCA FINANCEIRA E SUAS APLICAÇÕES. 12a edição. São Paulo: Atlas, 2012.

[2] Banco Central do Brasil. Estratégia Nacional de Educação Financeira (ENEF). Brasil, URL http://www.bcb.gov.br/?ENEFDOC. Acesso em: 15 de Maio de 2016.

[3] Banco Central do Brasil. Caderno de Educação Financeira - Gestão de Finanças Pessoais. Brasília: BCB, 2013.

URL http://www.bcb.gov.br/pre/pef/port/caderno_cidadania_financeira.pdf. Acesso em: 10 de Março de 2016.

[4] Banco Mundial. Workshop ENEF - Results of the impact evaluation into the financial education pilot project in schools in 2010. Washington D.C., Jun 2011.

URL http://documents.worldbank.org/curated/pt/2011/06/16334120/workshopenef-results-impact-evaluation-financial-education-pilot-project-schools-2010.

Acesso em: 15 de Maio de 2016.

[5] BRASIL. Ministério da Educação. Orientações Curriculares Nacionais. Brasília: MEC, 2006.

[6] BRASIL. Ministério da Educação. Secretaria de Educação Média e Tecnológica. Parâmetros Curriculares Nacionais (Ensino Médio). Brasília: MEC, 2000.

[7] BRASIL. Ministério da Educação. Secretaria da Educação Média e Tecnológica. Parâmetros Curriculares Nacionais + $(\mathrm{PCN}+)$ - Ciências da Natureza e suas Tecnologias. Brasília: MEC, 2002.

[8] BRUNI, Adriano Leal; FAMÁ, Rubens. A matemática das finanças. São Paulo: Atlas, 2003. 
[9] Caixa Econômica Federal. Simulador Habitacional CAIXA. URL http://www.caixa.gov.br/voce/habitacao/Paginas/default.aspx?pk_campaign= feirao2016\&pk_kwd=botao_home_habitacao. Acesso em: 15 de Maio de 2016.

[10] Comitê Nacional de Educação Financeira (CONEF). Educação financeira nas escolas: ensino médio. Brasília: CONEF, 2013.

[11] D'AQUINO, Cássia. Educação financeira: como educar seu filho. Rio de Janeiro: Elsevier, 2008.

[12] DANTE, Luiz Roberto. MATEMÁTICA: Volume único. $\mathbf{1}^{\mathbf{a}}$ edição. São Paulo: Ática, 2011.

[13] GIOVAnNI, José Ruy; GIOVAnNi JÚNIOR, José Ruy; BOnJORNO, José Roberto. Matemática Fundamental: uma nova abordagem. 2.ed. São Paulo: FTD, 2011.

[14] GONÇALVES, Jean Piton. A História da Matemática Comercial e Financeira. URL www.somatematica.com.br/historia/matfinanceira. Acesso em 12 de fevereiro de 2016.

[15] HALFELD, Mauro. Investimentos: como administrar melhor seu dinheiro. 3. ed. São Paulo, SP: Editora Fundamento Educacional, 2007.

[16] IEZZI, Gelson, HAZZAN, Samuel, DEGENSZAJN, David, Fundamentos de matemática elementar, volume 11, $1^{\text {a }}$ edição, São Paulo: Atual, 2004.

[17] LIMA, Elon Lages; CARVALHO, Paulo Cezar pinto; WAGNER, Eduardo; MORGADO, Augusto César. A Matemática do Ensino Médio. v. 2. 6. ed. Rio de Janeiro: SBM, 2006.

[18] MARTINS, José Pio. Educação Financeira ao alcance de todos: adquirindo conhecimentos financeiros em linguagem simples. 1.ed. São Paulo SP: Editora Fundamento Educacional, 2004. 
[19] OCDE - ORGANIZAÇÃO PARA A COOPERAÇÃO E DESENVOLVIMENTO ECONÔMICO. Improving Financial Literacy: Analysis of issues and policies. Paris, 2005. $181 \mathrm{p}$.

[20] ZENTGRAF, Roberto; GIANBIAGI, Fabio. O futuro é hoje: educação financeira para não economistas. Rio de Janeiro: Elsevier, 2010. 